\title{
Gobierno y gubernamentalidad en la obra de Michel Foucault
}

"Respondo: si existen relaciones de poder a través de todo el campo social es porque por todas partes hay libertad[...]la afirmación "Usted ve poder en todas partes así que no hay libertad" me parece absolutamente inadecuada. No se me puede atribuir la idea de que el poder es un sistema de 
dominación que lo controla todo y que no deja ningún espacio a la libertad”.

Michel Foucault

“El poder sólo se ejerce sobre sujetos libres y sólo en tanto ellos sean libres [...]En el corazón mismo de las relaciones de poder y constantemente provocándolas, están la resistencia de la voluntad y la intransigencia de la libertad".

Michel Foucault

"La sumisión es la muerte".

Ricardo Flores Magón

"Si yo no ardo

si tú no ardes

si nosotros no ardemos

¿Quién iluminará esta oscuridad?...”

En una manta en las "islas” de Ciudad Universitaria el miércoles 30 de mayo de 2012

En agradecimiento absoluto a mi familia, mis amigos, mis profesores y mis alumnos.

A mis padres, a mi hermano y a José Luis Lugo. 
Con enorme admiración, al Dr. Sergio Pérez por su invaluable apoyo, sus enriquecedoras clases y sus certeros consejos.

Al Dr. Gustavo Leyva con todo mi respeto y admiración intelectual.

Al Dr. Jesús Rodriguez Zepeda por su apoyo académico y administrativo.

A mis compañeros del posgrado, en especial a Gerardo, Guillermo, Xochitl y Javier.

Hay experiencias que cambian la vida, nada más enriquecedor que conocerlos a ustedes. Las convicciones compartidas nos colocaron juntos de forma azarosa e involuntaria, la amistad, en cambio, nos mantiene unidos de manera permanente y decidida. Con la esperanza de que aun el día en que las asambleas se eternicen, los observadores (en aras de colonizar el movimiento)se

reproduzcan de formas inexplicables y antinaturales, los deslindes se multipliquen hasta el límite del absurdo, las consignas se agoten de tanto repetirlas y las televisoras nos desaparezcan del mundo (e incluso del submundo), nuestro imperioso deseo de cambiar este país permanezca intacto. A mis amigos de \#YoSoy132.

\section{ABREVIATURAS}

AS Arqueología del saber.

CV El coraje de la verdad. 
DS Defender la sociedad.

GSO El gobierno de síy de los otros.

HS1 Historia de la sexualidad. 1.

HS2 Historia de la sexualidad. 2.

LA Los anormales.

LS La locura y la sociedad.

MF Foucault.

MP Microfísica del poder.

NB Nacimiento de la biopolítica.

OD El orden del discurso.

OE Obras esenciales.

QI ¿Qué es la llustración?

QC ¿Qué es la crítica?

VC Vigilar y Castigar.

VFJ La verdad y las formas jurídicas.

SP Le sujet et le pouvoir.

STP Seguridad, territorio y población.

TY Tecnologías del Yo. 
Índice

I.- El proyecto crítico de Michel Foucault. (Aclaraciones al proyecto filosófico de Foucault a la luz de las críticas de Habermas)

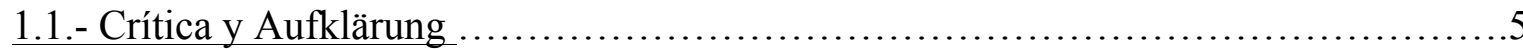

1.2.- La intención del proyecto crítico de Foucault

(La práctica filosófica como un estudio de las condiciones de nuestra experiencia histórica

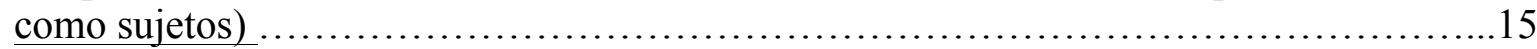

1.3.- El papel de la problemática del poder en el proyecto general de una historia crítica del

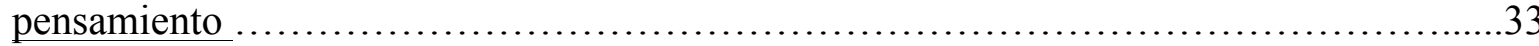

II.- El paso de la noción de poder a los conceptos de gobierno y gubernamentabilidad.....................................................................49

2.1.- Desplazamiento del modelo jurídico-económico..................................52

2.1.1.- El modelo economicista................................................52

2.1.2.- El modelo jurídico...................................................62

2.1.3.- El modelo de lucha y represión.......................................72

2.1.3.1.- La hipótesis represiva.........................................72

2.1.3.2.- La hipótesis Nietzche...........................................79

2.2.- Gobierno y gubernamentalidad...................................................... 87

2.2.1.- Gubernamentalidad y resistencia....................................99

III.- Distinción entre los conceptos de racionalidad en Habermas y Foucault. (A modo de conclusión: balance general de la crítica foucaultiana frente al modelo

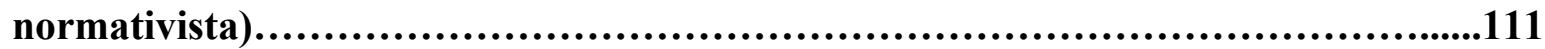

3.1.- La racionalidad comunicativa como fundamento de la posición crítica en

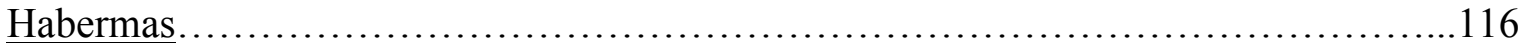


3.2.- Procesos de racionalización y gubernamentalización. El análisi histórico genealógico y arqueológico como fundamento de una crítica social....................127

Bibliografía................................................................................137 


\section{I.- El proyecto crítico de Michel Foucault.}

\section{(Aclaraciones al proyecto filosófico de Foucault a la luz de las críticas de \\ Habermas)}

Sin duda una de las polémicas filosóficas más prolíficas de la segunda mitad del siglo XX, fue protagonizada por las posturas de Michel Foucault y Jürgen Habermas. En el famoso libro titulado El discurso filosófico de la modernidad, Habermas retoma el trabajo del francés y realiza una crítica minuciosa del mismo. En ella, denuncia la existencia de ciertas insuficiencias y ambigüedades que, a su parecer, hacen insalvables los planteamientos de Foucault. El francés, por el contrario, es más parco al respecto, le dedica pocas palabras al trabajo del alemán y no realiza ningún análisis pormenorizado de sus textos; sin embargo, el tono de sus referencias es más afable y pretende ser menos condenatorio, a tal grado que llega a afirmar "I am interested in what Habermas is doing. I know that he does not agree with I say -I am a little more in agreement with him" (Kelly, 1995, 1).

A diferencia de Habermas -quien en alguna ocasión llegó a tildarlo de "neoconservador"-, Foucault señala en varias ocasiones que su trabajo filosófico no pretende negar ni poner en entredicho la perspectiva habermasiana; por el contrario, únicamente se presenta como una forma de abordaje distinta. Forma de abordaje que, por su propia peculiaridad, puede resultar provechosa para la comprensión de nuestro presente en dimensiones que, probablemente, una "Teoría social crítica" no llega a vislumbrar o, si lo hace, no se le presentan como aspectos esenciales debido a sus características metodológicas. Por ello, nos parecen relevantes las palabras del autor de Vigilar y castigar que acabamos de citar; en buena medida muestran que la gama de análisis que realiza no pretenden erigirse como 
una "Teoría social crítica", ni fundamentar un "concepto de racionalidad" libre de los presupuestos de las filosofías previas, ni habilitar criterios normativos aptos para valorar las patologías de las sociedades modernas. Dado que éstas no son sus pretensiones, no intenta competir ni desbancar el edificio conceptual de Habermas y, por lo mismo, no necesita mostrar la falsedad de su postura ${ }^{1}$.

Esto último tiene cierta relevancia. La crítica fundamental que Habermas dirige a Foucault en El discurso filosófico de la modernidad afirma que la propuesta filosófica de este último eleva inconscientemente a trascendental un concepto "irritante de poder"2. Al hacerlo, obtiene como resultado una "Teoría social" unilateral que reduce el desarrollo de la modernidad a la lógica del "avasallamiento". Según Habermas, esta reducción se explica por el olvido foucaultiano de los procesos de valoración, normatividad y entendimiento. Para el alemán, una "teoría" que simplifica la configuración de la realidad a las dinámicas de lucha, no puede explicar cómo fue posible que de esas luchas surgieran procesos organizados e institucionalizados. Según Habermas, esto sólo se podría entender si Foucault fuera más allá de la mera dimensión del avasallamiento y tomara en cuenta, ya sea

\footnotetext{
${ }^{1}$ Cosa que Habermas realiza claramente en El discurso filosófico de la modernidad; (Cfr. Habermas, 2010, 322ss).

${ }^{2}$ Cuando Habermas afirma que Foucault eleva el concepto de poder a trascendental, denuncia que, en el fondo, cae en la misma aporía con la que él criticaba a las ciencias humanas en Las palabras y las cosa; a saber, el doblete empírico-trascendental. Es decir, la elevación a trascendental de datos empíricos con el fin de que estos últimos sirvieran como criterio de análisis objetivo. Para Habermas, Foucault hace del poder un concepto capaz de moverse tanto en la dimensión empírica como en la trascendental y sólo por medio de esa duplicidad soluciona las dificultades de análisis que su arqueología del saber manifestaba. En un artículo titulado "Racionalidad, fuerza y poder. Foucault y las críticas de Habermas" Dominique Janicaud aclara que el punto medular de la crítica de Habermas a Foucault consiste en señalar una "ambigüedad sistemática" que: "[...] se despliega en toda la obra [...] pero tiene su fuente en el concepto mismo de poder que guía más especialmente las indagaciones de Foucault en sus últimos años. "Ambigüedad sistemática" evidentemente quiere decir mucho más que fluctuaciones entre lo empírico y lo metaempírico o hasta que una ambivalencia de hecho $[\ldots]$ "Ambigüedad sistemática" quiere decir ciertamente que uno comprueba un "papel doble", desconcertante y hasta irritante, del concepto de poder al cuál se le asigna la doble función de estructura y de instancia de regulación. Pero esa expresión quiere decir sobre todo lo que permite ese doble juego al unir por fuerza el "pensamiento idealista de una síntesis trascendente" con los "supuestos de una ontología empírica". Foucault permite al primero eximirse de dar sus títulos y a la ontología empírica cubrir sus casos de "déficit empírico"(Balbier [sic.], Deleuze, 1990, 282).
} 
una teoría de sistemas, ya sea una teoría del intercambio o una "Teoría de la acción comunicativa". Pero inmerso en el callejón sin salida del poder, el autor de Vigilar y castigar se habría enredado en un marasmo irresoluble que reduce la historia al desarrollo indiferenciado de luchas perpetuas ${ }^{3}$ :

$\mathrm{Si}$, como hace Foucault, sólo se admite el modelo de procesos de avasallamiento, de confrontaciones mediadas por el cuerpo, de contextos de acción estratégica más o menos consciente; si se excluye toda estabilización de ámbitos de acción a través de valores, normas y procesos de entendimiento, y estos mecanismos de integración social no son sustituidos por ninguno [...] entonces apenas y se puede explicar cómo tal perpetuo rebullir de luchas locales podría consolidarse en un poder institucionalizado (Habermas, 2010, $313)^{4}$.

A nuestro entender, el diagnóstico de Habermas yerra por una razón muy sencilla: supone que el proyecto del francés tiene las mismas pretensiones que el suyo. El autor de Facticidad y validez, asume que Foucault pretende realizar una "Teoría social crítica" capaz de generar un diagnóstico de la modernidad". Desde esta perspectiva la "Teoría" foucaultiana sería totalmente insatisfactoria por dos motivos: 1) Porque reduciría la complejidad del desarrollo de la modernidad a la evolución de relaciones de $\operatorname{poder}^{6}$ y 2) porque neutralizaría todo su posible contenido "crítico" al hallar formas de poder en todas nuestras prácticas. El argumento de Habermas respecto a este último punto es el siguiente:

\footnotetext{
${ }^{3}$ Esta interpretación es recogida por muchos autores, en especial por Honneth en Crítica del poder. En su libro Legitimación y racionalización, Enrique Serrano reproduce acríticamente esta interpretación sin un análisis pormenorizado del trabajo completo de la obra de Foucault, limitándose únicamente a textos de la primera mitad de los 70's sin valorar la profunda transformación de los trabajos del francés a partir de la segunda mitad de esa década y malentendiendo su preocupación por el tema de la parrhesía (Cfr, Serrano, 1994, 58ss).

${ }^{4}$ En este punto las conclusiones de la interpretación de Honneth son idénticas, (Cfr., Honneth, 2009, 263ss).

${ }^{5}$ A pesar de que Honneth pretende ser más comprensivo en su diagnóstico, en más de una ocasión reitera este error, por ejemplo en su Crítica del poder afirma una y otra vez que: "[...] Foucault desarrolla las líneas básicas de una teoría de la modernidad europea [...]"(Honneth, 2009, 170-171).

${ }^{6}$ A lo largo de este trabajo trataremos aclarar dos cosas: 1) Foucault jamás intentó realizar una "Teoría social" y 2) si se analizan con seriedad los trabajos foucaultianos de la segunda mitad de la década de los 70's resulta imposible afirmar que el francés reduzca el proceso social de la modernidad al desarrollo de relaciones de avasallamiento.
} 
si Foucault tuviera razón al afirmar que todos nuestros discursos están atravesados por relaciones de poder, resultaría imposible generar criterios válidos para denunciar las patologías sociales que el francés, de hecho, desea criticar ${ }^{7}$. En este apartado intentaremos mostrar porqué resulta adecuado caracterizar la filosofía de Foucault como una filosofía crítica incluso si tomamos en cuenta la argumentación de Habermas. De manera semejante a lo que opina Olivier Voirol en su artículo "Crítica genealógica y crítica normativa"8 pensamos que, en el fondo, Foucault formula una propuesta de "pensamiento crítico" totalmente distinta a la de Habermas. Por tal motivo, los fines y los medios que cada uno concibe son radicalmente divergentes. Foucault elabora un análisis al respecto en una conferencia de 1979 titulada “¿Qué es la crítica?”, esta última prefigura el célebre texto “¿Qué es la Ilustración?” publicado en 1984. Curiosamente, nuestro autor problematiza el papel "crítico" de su trabajo en un periodo tardío y -cosa rara- en relación con una figura de la que tiempo atrás se había desplazado: Kant. Tanto en el texto de 1979, como en el artículo de 1984 -recién mencionados-, nuestro autor vuelve sobre la pregunta que el filósofo de Köninsberg realiza en 1784: “Was ist Aufklärung?”. Lo relevante de ambos trabajos no es, a nuestro parecer, lo correcto o incorrecto de su interpretación sobre el texto kantiano, sino la clave que nos puede dar respecto a sus propios análisis. Y es que, en los textos mencionados, Foucault nos entrega una revisión reflexiva de su filosofía en la que se unifica la intención de todos sus estudios. Quizá lo más conveniente para comprender adecuadamente su trabajo sea comenzar por estos textos, desde nuestra perspectiva éstos

\footnotetext{
${ }^{7}$ Por ejemplo Enrique Serrano formula que la teoría de Foucault no puede conformarse únicamente con un descriptivismo inocuo porque carecería de todo potencial crítico.

${ }^{8}$ Véase "Crítica genealógica, crítica normativa" en: (Cusset, Haber (dir), 2006, 127-148). Para la polémica entre Habermas y Foucault también puede consultarse el libro Critique and Power. Recasting the Foucault/Habermas Debate (Kelly,1995).
} 
nos permitirán entender las razones que llevaron al francés a caracterizar su proyecto como una "Historia crítica del pensamiento".

\section{1.- Crítica y Aufklärung}

El famoso artículo “¿Qué es la ilustración?” escrito por Kant en 1784, posee un valor privilegiado para Foucault. A su entender dicho escrito une dos aspectos que, a la postre, serán esenciales en la historia de la filosofía. En primer lugar, el texto publicado en el Berlinische Monatschrift no sólo caracteriza la Aufklärung como el resultado del desarrollo de ciencias y saberes precisos, sino como la emergencia de una disposición frente al mundo. En efecto, la presentación que el alemán hace de la Ilustración no se limita a elogiar el desarrollo de los conocimientos científicos de la época, sino que abarca lo que bien podría llamarse una actitud ante la realidad. Esta actitud se manifiesta a través de un deseo irrefrenable de liberación, de emancipación de todas las tutelas que nos prohíben pensar por nosotros mismos. El francés enfatiza, en segundo lugar, que dicha actitud se produce como parte de un acontecimiento histórico específico del cual Kant es consciente. Para Foucault, resulta totalmente novedosa la reflexión del alemán, porque remite a una preocupación por nosotros mismos en tanto sujetos de un acontecimiento histórico. Nuestro filósofo cree que en ese texto en concreto el autor de la Metafísica de las costumbres hace irrumpir una pregunta que a lo largo de la historia de la filosofía no se había formulado con total seriedad, a saber: ¿Quiénes somos nosotros en tanto seres presentes?, ¿quiénes somos nosotros y en qué consiste esta actualidad que habitamos? ${ }^{9}$

\footnotetext{
9 "Sin duda no es la primera vez que un filósofo da las razones que tiene para emprender su obra en tal o cual momento. Pero me parece que es la primera vez que un filósofo enlaza de esta manera, estrechamente y desde el interior, la significación de su obra con relación al conocimiento, una reflexión sobre la historia y un análisis particular del momento singular en el que escribe y a causa del que escribe. La reflexión sobre el
} 
En el centro de esta reflexión se encuentra el difícil problema de la autonomía. Foucault enfatiza que el análisis sobre la Ilustración hecho por el alemán, muestra la aparición de eso que él llama un ethos filosófico; pero insiste en que este ethos es histórico al menos en dos sentidos: 1) porque se presenta dentro de un acontecimiento específico, temporalmente ubicable. Es decir, lo que nos invita a ejercer nuestra autonomía y luchar por ella no es una mera exigencia espontánea de la razón, sino una actitud históricamente constituida; y 2) porque la pregunta por la Aufklärung es la pregunta por nosotros en tanto seres históricos, en tanto seres concretos en un presente específico. En esencia, es esta relación entre filosofía, historia y autonomía, lo que a Foucault le interesa rescatar de la perspectiva kantiana $^{10}$.

Si es verdad que nuestro autor retoma a Kant para formular su idea de crítica, no es, como se podría esperar, una remisión al Kant de la Crítica de la razón pura o de la Crítica de la razón práctica, menos aún al de la Crítica del juicio. A contrapelo de los estudios de su época, el francés realiza una interpretación sui generis del trabajo kantiano, pues considera que el filósofo de Köninsberg inaugura al menos dos formas de pensamiento filosófico: por un lado lo que comúnmente se denomina filosofía "Crítica" y, por el otro, la problemática sobre la Ilustración. En ésta última convergen al menos dos elementos: la pregunta por el presente y una actitud históricamente constituida que deriva en el intento de consolidarnos como sujetos autónomos: “Quería subrayar [...] el enraizamiento en la Aufklärung de un

«hoy» como diferencia en la historia y como motivo para una tarea filosófica particular es, en mi opinión, la novedad de este texto" (QI, 980). A nuestro modo de ver Foucault sobrevalora este punto dentro del texto kantiano, aunque en cierta medida el alemán efectivamente está preocupado por la Ilustración en tanto suceso contemporáneo: "Nuestra época -afirma- es la época de la Ilustración" (Kant, 2006A, 35).

10 "Mais la question qui posse Kant est différente: qui sommes nous, à ce moment précis de 1'histoire? Cette question, c'est à la fois nous et notre situation présente qu'elle analyse" (SP, 1051). 
tipo de interrogación filosófica que problematiza, a la vez, la relación con el presente el modo de ser histórico y la constitución de sí mismo como sujeto autónomo" (QI, 984).

Kant habría puesto las bases de dos dimensiones de análisis filosófico. Por un lado la "Crítica" en el sentido de los grandes textos kantianos -Crítica de la razón pura, Crítica de la razón práctica y Crítica del juicio- y, por el otro, la pregunta por nosotros mismos en tanto seres del presente. Según el francés, la filosofía "Crítica" tendría como objetivo analizar "las condiciones de legitimidad y constitución del conocimiento" en el pequeño texto: “¿Qué es la ilustración?” el alemán, aun sin ser consciente de ello, pondría las bases de otro tipo de reflexión. Para diferenciarla de la filosofía "Crítica" Foucault decide nombrarla simplemente Aufklärung. La Aufklärung, en tanto preocupación por el presente, pondría en juego una actitud que busca la liberación de toda tutela exterior a través de una reflexión histórica sobre nuestra actualidad. Según Foucault, esta actitud crítica dirigida al presente es lo que puede vincularnos con la Ilustración: "he querido insistir en que el hilo que puede unirnos de ese modo a la Aufklärung no es la fidelidad a ciertos elementos de doctrina, sino, más bien, la permanente reactivación de una actitud; es

${ }^{11}$ En cierto sentido podríamos afirmar que la empresa "Crítica" kantiana tiene por objetivo delimitar los criterios mínimos que requiere un juicio para detentar legítimamente sus pretensiones de validez. Si por juicio entendemos, con Kant: "la representación de la unidad de la conciencia de diversas representaciones", debemos afirmar que el juicio es la condición que vuelve inteligible el mundo. Así, los distintos tipos de juicios se nos presentan como distintas perspectivas para hacer inteligible el mundo. En la Crítica de la Razón Pura, por ejemplo, Kant intenta mostrar las condiciones necesarias para la validez objetiva de un juicio. Esto supone una síntesis de la multiplicidad empírica de las sensaciones con la unidad de una categoría. Esta síntesis, por su parte, genera un concepto empírico, pero éste sólo puede pretender legítimamente: a) objetividad, si hace referencia a la "experiencia posible", y b) justificación de esa objetividad, si la referencia a esa experiencia se adecua a determinadas reglas, las cuales deben ser ubicadas en los principios del entendimiento. En el caso de la Razón práctica, nos las vemos con un tipo de juicio específico que no puede justificar sus pretensiones de validez haciendo referencia a la experiencia posible, por lo que deberá buscar el correlato que garantice su sentido, ya no en lo que "es", sino en lo que "debe" ser. Como carece de referente en el campo de la experiencia posible, su validez tendrá que buscarse únicamente en los principios de la razón. Como podemos constatar, nos encontramos, en ambos casos, ante la búsqueda de las condiciones legítimas para la validez de un juicio. Hay que aclarar aquí que Foucault usa indiscriminadamente el concepto "conocimiento" que, en Kant, tiene un sentido bien preciso. Debemos agregar que sería más provechoso entender "condiciones legítimas de la razón" en aquellos lugares en que Foucault habla de condiciones legítimas del conocimiento. 
decir, de un ethos filosófico que se podría caracterizar como una crítica permanente de nuestro ser histórico" (QI, 984).

Ahora bien, nuestro filósofo cree que el propio Kant considera que ambos elementos son correlativos, pues sólo dentro de un periodo como la Ilustración se vuelve factible e incluso necesario preguntarnos por las condiciones legitimas de nuestros juicios: “[...] es precisamente en un momento como ese [La Ilustración] que la Crítica se hace necesaria, puesto que ella tiene por misión la definición de las condiciones bajo las cuales es legítimo el uso de la razón para determinar lo que se puede conocer, lo que se debe hacer y lo que se puede esperar"12 (QI, 980). Sólo porque históricamente el hombre comienza a buscar liberarse de toda tutela exterior y utilizar su razón de forma autónoma, es que tiene sentido preguntarse por las condiciones legítimas de ese uso. Si siguiéramos admitiendo todo gobierno exterior sin ningún reparo, esa pregunta carecería de sentido. Así, la necesidad de determinar los límites de la razón tiene, como fin último, establecer su uso legítimo para evitar el peligro, ora de una suerte de relativismo anarquista, ora de una imposición que necesariamente llevaría a la coartación de nuestra libertad:

El uso ilegítimo de la razón hace nacer, por medio de la ilusión, al dogmatismo y la heteronomía; por el contrario, cuando el uso legítimo de la razón ha sido claramente definido en sus principios es que puede asegurarse su autonomía. En algún sentido la Crítica es el libro-guía de la razón que ha alcanzado su madurez en la Aufklärung, e inversamente, la Aufklärung es la edad de la Crítica” (QI, 980).

Para Foucault la relación entre Aufklärung y filosofía "Crítica" dentro de la filosofía kantiana resulta esencial, a tal punto que la interrogación por la Aufklärung nos reenvía de

\footnotetext{
${ }^{12}$ Para Foucault las tres condiciones mencionadas corresponden con las tres preguntas kantianas establecidas en la Lógica: ¿Qué puedo conocer?, ¿qué debo hacer?, y ¿qué me cabe esperar? Según el francés, las tres Críticas de Kant están atravesadas por la exigencia de autonomía propia de la Ilustración.
} 
inmediato a la filosofía "Crítica". Esto porque la conquista de nuestra autonomía depende del hallazgo de los límites legítimos de la razón:

[...] en relación con la Aufklärung la crítica será a los ojos de Kant lo que dirá al saber: «¿Sabes bien hasta dónde puedes saber?, razona tanto como quieras, pero ¿sabes bien hasta dónde puedes razonar sin peligro? ». La crítica dirá, en suma, que nuestra libertad se juega menos en lo que emprendemos, con más o menos coraje, que en la idea que nos hacemos de nuestro conocimiento y de sus límites y que, en consecuencia, en lugar de dejar que otro diga «obedece», es en ese momento, cuando nos hayamos hecho del propio conocimiento una idea justa, cuando podremos descubrir el principio de la autonomía y cuando ya no tendremos que oír el obedece; o más bien el obedece se fundamentará sobre la autonomía misma $(\mathrm{QC}, 13)$.

Este último punto es fundamental. Según Foucault, Kant relaciona Aufklarüng y filosofía "Crítica" desde una perspectiva bastante peculiar. Esta vinculación se ve con claridad en la filosofía práctica del alemán, en ella la libertad del sujeto únicamente se hace presente si el hombre dilucida los límites legítimos de la razón y, al hacerlo, se da a sí mismo las leyes de su acción ${ }^{13}$. Como se pude ver, la autonomía no es el resultado de la creación arbitraria de leyes personales; al contario, la ley que comanda nuestra acción debe adecuarse al análisis de las condiciones legítimas de una racionalidad entendida en términos trascendentales. Foucault enfatiza la existencia de este lazo que uniría la autonomía, por un lado, y el análisis de las condiciones legitimas para el uso de nuestra razón, por el otro.

Ahora bien, según el francés, en mayor o menor medida, la filosofía moderna embebe de las dos formas de pensamiento inauguradas por Kant: Crítica y Aufklärung. Nuestro autor

\footnotetext{
13 Siguiendo a Kant podemos ir un poco más allá. Tal como es planteado en la Metafísica de las costumbres y en la Crítica de la Razón Práctica, la ley moral manifiesta la libertad únicamente en cuanto carece de toda motivación extrínseca a la pura racionalidad, de tal manera que la autonomía depende de que el sujeto halle las condiciones legitimas que harían de su ley una ley enteramente racional. El hombre es autónomo cuando puede darse una ley conforme a los dictados de una racionalidad depurada de toda motivación extrarracional.
} 
señala que, efectivamente, gran parte de la filosofía del siglo XX es heredera del espíritu de la Aufklärung; es decir, de esa actitud crítica que lucha por nuestra autonomía. De igual forma gran parte de las filosofías del siglo XX sostienen, como Kant, que la búsqueda de la autonomía nos reenvía obligatoriamente al problema de los límites legítimos de la razón. A pesar de sus múltiples variantes, Foucault cree localizar una tendencia que hace coincidir la búsqueda de autonomía con el análisis de las condiciones de legitimidad del conocimiento en un sector amplio de la filosofía que le es contemporánea. En efecto, si bien es cierto que estas filosofías niegan la necesidad de llevar a cabo fundamentaciones ontológicas o trascendentales $^{14}$, dirigen su preocupación histórica hacia el lugar de la "Crítica" en el sentido estrictamente kantiano. Grosso modo podemos decir, siguiendo a Foucault, que después de Kant la búsqueda de las condiciones legítimas de nuestros juicios, tendió a reformularse en moldes históricos, pero el espíritu de esos análisis siguió anclado en la esencia de la filosofía "Crítica". De una u otra forma los procedimientos filosóficos a los que Foucault alude, se definen por su intento de hallar las condiciones formales de un concepto de racionalidad legítimo, el cual ejercería la función de parámetro evaluativo respecto a la validez de nuestros juicios y expectativas. Según el francés, este tipo de trabajos tienen el objetivo de responder la pregunta "por las condiciones de legitimidad de los modos históricos de conocer [...] buscando cómo se habría operado en la historia el tránsito fuera de la legitimidad (ilusión, error, olvido, encubrimiento, etc.)” (QC, 24).

Así, gran parte de la filosofía del siglo XX habría intentado sacar a Kant de su ahistoricidad y reformular la pregunta por las condiciones "legítimas" para validar nuestras presunciones de verdad, rectitud o veracidad; para la generación de juicios "adecuados"

\footnotetext{
${ }^{14}$ (Cfr, Habermas, 2008 B, 15ss).
} 
sobre el hombre y su "naturaleza", o para diagnosticar el momento definitorio del descalabro de nuestra racionalidad. Ya sea apelando a la exigencia de reformular "correctamente" la verdadera pregunta de la filosofía, ya sea basándonos en análisis históricos que, de una u otra manera, nos mostrarían cómo las "patologías" de la modernidad son el resultado de la escalada ilegitima de un dominio de racionalidad sobre otro, en todos los casos se trata de examinar cuáles son las condiciones legítimas para la adecuada elaboración de nuestros juicios o para el diagnóstico crítico de la sociedad.

Sin lugar a dudas el trabajo que más ha logrado avanzar en esta dirección es el de Habermas. Al menos en lo tocante a este punto, su proyecto se presenta como una prolongación depurada de la "filosofía Crítica" kantiana ${ }^{15}$. Gran parte de los escritos del filósofo alemán tienen la intención de hallar, ya no en un sujeto trascendental, sino en la praxis comunicativa, los presupuestos implícitos que posibilitan el entendimiento intersubjetivo. En el fondo de este proceder se halla la intención de fundamentar criterios normativos sólidos para nuestra actividad práctica ${ }^{16}$. En Teoría de la acción comunicativa, el alemán deja claro que su propósito "[..] ha sido [...] introducir una teoría de la acción comunicativa que dé razón de los fundamentos normativos de una teoría crítica de la sociedad" (Habermas, 2008 C, 562). Con esa intención en mente, el autor de Verdad y justificación desplaza sus análisis hacia la pragmática formal, pues ésta se le presenta como un instrumento teórico particularmente útil en varios niveles. En primer lugar, le sirve de

\footnotetext{
${ }^{15}$ Véase "Caminos hacia la destrascendentalización. De Kant a Hegel y vuelta atrás” (Habermas, 2007,181222).

${ }^{16}$ En Teoría de la acción comunicativa y con mayor prolijidad en Verdad y justificación, analiza las tres "estructuras centrales" de racionalidad del entendimiento existentes y establece las expectativas legítimas para el uso de cada una de ellas. Habermas distingue entre razón teleológica, razón epistémica y razón comunicativa y aclara que las tres se encuentran ensambladas entre sí de "forma integradora" por la racionalidad discursiva, luego busca las condiciones que hacen validas nuestras expectativas al momento de hacer uso de cada una de ellas (Cfr, Habermas, 2007, 99ss).
} 
anclaje para una teoría crítica de la sociedad, pero también le permite superar las objeciones clásicas de quienes le reprocharían sostener un proyecto de esa envergadura en "fundamentaciones últimas" o suponer la existencia de una "filosofía primera". Según Habermas, la pragmática formal no remite ni a un fundamento último y a-histórico, ni a un sujeto trascendental, mucho menos a una visión totalizante del mundo; todo lo contrario: deduce los criterios normativos de la práctica lingüística cotidiana ${ }^{17}$. Este instrumento teórico también le permite alejarse de todo posible relativismo, pues aun evitando toda fundamentación última sigue manteniendo "pretensiones" de universalidad y necesidad. Estas pretensiones, sin embargo, ya no se defienden a la luz de un "sujeto trascendental", ni pretenden hallar las "condiciones de toda experiencia posible", sino que se sostienen en criterios fundados en las reglas prácticas por medio de las que nos hemos socializado. Con lo cual, se trata menos de indagar las condiciones a priori para toda experiencia posible que de dilucidar aquellas reglas que resultan "inevitables" e "irrebasables"18 para el ejercicio cotidiano de nuestra práctica comunicativa.

Ahora bien, a diferencia de teorías de la acción como la de Weber que, según Habermas, termina limitando el concepto de racionalidad al de racionalidad con arreglo a fines ${ }^{19}$; el alemán cree necesario tomar en cuenta el paradigma del lenguaje para explicar aquellas acciones que presuponen un entendimiento entre personas ${ }^{20}$. La ventaja de esta formulación

\footnotetext{
17 "Al formalizar las condiciones universales de la comunicación social, Habermas combinaba esta crítica con una dimensión trascendental a la cual está asociada la pragmática universal, que se orienta a dar cuenta de las reglas en uso en la comunicación corriente y que estructura toda situación en que interviene la palabra"(Cusset, Haber (Dir.), 2006, 130).

${ }_{18}^{18}$ (Cfr., Habermas, 2008 A, 18-19).

${ }^{19}$ (Cfr, Habermas, 2008 B, 197-330).

${ }^{20}$ Ya en Ciencia y técnica como ideología, el alemán realizaba una distinción entre trabajo e interacción, la cual, según su punto de vista, le permitía deslindarse del paradigma subjetivista. En el caso del trabajo nos encontraríamos frente a una acción con arreglo a fines, misma que tendría como objetivo disponer
} 
se podría resumir en lo siguiente: la fundamentación de las pretensiones de validez (verdad, rectitud, veracidad) ${ }^{21}$ de nuestras acciones en el "mundo de la vida" no dependerían ya, ni de la problemática reflexividad de un sujeto consigo mismo, ni de un concepto de razón reducido a la mera instrumentalidad, sino de la asunción de la segunda y la tercera persona necesariamente implícitas en la pretensión de entendimiento insertas en nuestro lenguaje ${ }^{22}$.

A la par, y basado en los criterios normativos que la acción comunicativa ofrece, Habermas intenta sustentar una "teoría de la sociedad". En ella, realiza una distinción esencial: de un lado establece el marco de análisis de la esfera social que se vincula con la acción comunicativa; del otro, dibuja los límites de la esfera social que se circunscribe a la reproducción técnica y material. En la primera, las expectativas de nuestra acción presuponen ciertos criterios normativos que, si bien pueden no cumplirse en algunas ocasiones, son condiciones de posibilidad del entendimiento; la segunda se encuentra ligada a la búsqueda de éxito en la manipulación de objetos y procesos. En buena medida, la progresiva colonización de la esfera instrumental sobre la esfera vinculada a relaciones de entendimiento y comunicación, explicaría las patologías sociales que marcan nuestro presente $^{23}$. Usando los instrumentos teóricos que la pragmática formal le otorga, Habermas fundamenta criterios normativos para sostener de manera sólida una "Teoría social crítica".

adecuadamente los medios para controlar la realidad, en esta actividad nuestra relación primordial sería con objetos. Habermas señala que: "[...] aquí realizaríamos experiencias con cosas, sucesos y estados que son esencialmente susceptibles de manipulación" (Habermas, 1999, 19). La interacción, por su parte, remitiría a una acción comunicativa en la que: "[...] nos encontraríamos con objetos del tipo de sujetos hablantes y actuantes; aquí realizamos experiencias con personas, exteriorizaciones y estados que están estructurados y son comprensibles de manera esencialmente simbólica" (Habermas,1999, 19). La interacción nos inserta en el terreno de la "praxis comunicativa", ésta tiene entre sus funciones la generación de entendimiento entre los sujetos interactuantes en un "mundo de la vida" compartido. El análisis de esta función remite a un territorio intersubjetivo que, necesariamente, depende de la dinámica del lenguaje. De ella se deducen las estructuras normativas que sirven como criterios para nuestra acción práctica.

${ }^{21}$ (Cfr, Habermas, $2008 \mathrm{~B}, 143 \mathrm{ss}$ ).

${ }^{22}$ (Cfr, Habermas, 2007, 10ss).

${ }^{23}$ (Cfr, Honneth, 2009, 114). 
Esto supone, sin duda, una perspectiva de análisis que parte de la siguiente convicción: la capacidad crítica de un análisis social del presente, supone una delimitación previa de las condiciones de validez de nuestra racionalidad ${ }^{24}$.

Sin demeritar lo provechoso de esta posición, Foucault señala que es posible abordar un procedimiento diferente: “[...] yo quería trazar muy vagamente otras vías posibles, diferentes a las que me parece han sido hasta el presente más gustosamente frecuentadas. Lo cual no significa de ninguna manera acusarlas de no conducir a nada" (QC, 24). Esta última frase debe ser resaltada, el francés no cree que su postura niegue o refute las pretensiones de validez de aquellas posiciones que, seguramente con muy buenas razones, trazaron su camino teórico por la vía de la "normatividad". Al contrario, lo que se propone es otorgar una perspectiva de análisis distinta, que por su específica forma de proceder, tendría sus propios objetivos y también, hay que decirlo, sus limitaciones internas. A diferencia de Habermas, quien cree ver en la filosofía de Foucault una suerte de teoría social que trascendentaliza la noción de poder y, al hacerlo, niega cualquier posibilidad de crítica $^{25}$, el francés no desdeña de antemano los alcances de una “Teoría de la acción comunicativa" o, en general, de una filosofía que se presente como una búsqueda de las condiciones de legitimidad. Sin embargo, piensa que también es posible realizar otro tipo de análisis, el cual, como su propia experiencia le enseñó, puede llegar a ser igual o incluso más fértil en sus efectos. El tipo de análisis que el francés se propone fundamentar, trata de retomar la novedosa vinculación dibujada por Kant entre una actitud filosófica profundamente preocupada por la liberación de toda tutela exterior y el análisis de nuestro presente, esto con la intención de llevar a cabo una crítica histórica de nosotros mismos.

\footnotetext{
${ }^{24}$ (Cfr, Habermas, 2008 A).

${ }^{25}$ (Cfr, Habermas, 2010, 259ss).
} 
Pero dada su peculiaridad, este proyecto posee una serie de características bastante singulares que vale la pena conocer para no confundir sus pretensiones a la hora de juzgarlo. Veamos.

\section{2- La intención del proyecto crítico de Foucault}

(La práctica filosófica como un estudio de las condiciones de nuestra experiencia histórica como sujetos)

Foucault intenta abrir su propio camino siguiendo la senda esbozada por Kant. Él se propone entrar por la puerta de la Aufklärung no ya hacia el problema de las condiciones legítimas del conocimiento, sino hacia la indagación de lo que llama "procedimientos de eventualización”. Es decir, nuestro autor desea realizar una búsqueda de las condiciones de posibilidad absolutamente históricas, eventuales y contingentes, que hacen posible la aparición singular de ciertos focos de experiencia propios del presente, preguntándonos menos por la legitimidad o ilegitimidad de su configuración, que por la combinatoria de determinaciones que dieron lugar a su aparición. De tal manera que la preocupación histórica por nosotros mismos y la búsqueda de autonomía que la Aufkälrung pone en juego, no nos trasladarían a una "Crítica" de corte kantiano como vía de solución, sino a un procedimiento que tiene por finalidad buscar las determinaciones que hacen posible que ciertas formas de racionalidad específica irrumpan en el presente.

Si tomamos en cuenta estas afirmaciones, la relación de Foucault con la tradición crítica parece contradictoria. Sin embargo, la posición de nuestro filósofo resulta comprensible si aceptamos que no toda pretensión crítica debe reducirse al análisis de las condiciones que harían legítimo el uso de la razón. A nuestro entender, es posible ubicar algunos hilos 


\footnotetext{
${ }^{26}$ En Kant, esta búsqueda se pone de manifiesto claramente en su concepción epistemológica. En la Crítica de la razón pura, el alemán intenta dar cuenta de las condiciones que hacen posible nuestro acceso a los objetos de la experiencia. Una de las más grandes novedades de su trabajo, como es sabido, consiste en aquello que el propio autor llama revolución copernicana. En lugar de dar cuenta de las condiciones de posibilidad del conocimiento remitiéndose a los objetos de la experiencia, Kant desplaza la dirección del análisis y busca semejantes condiciones en la estructura de nuestra subjetividad (Cfr, Kant, 2006 A, BXIII, B34). Como es de todos conocido, el alemán termina concluyendo que esas condiciones de posibilidad se hallan en dos niveles del entendimiento: 1) En las intuiciones puras de espacio y tiempo (estética trascendental) (Kant, 2006, 65ss) y 2) En la tabla de categorías (lógica trascendental)(Kant,2006, 92ss). Las intuiciones ordenan las coordenadas de nuestra sensibilidad, mientras que la tabla de categorías le da inteligibilidad a la misma y permite su traducción discursiva para la emisión de juicios. Así, Kant logra superar la unilateralidad tanto del empirismo, como del racionalismo, al demostrar que nuestro acceso a los objetos se halla irremediablemente mediado por las condiciones trascendentales de nuestra subjetividad. Se ve con claridad que el análisis de las condiciones subjetivas del pensamiento, nos muestra también la manera en que se constituye nuestra experiencia fenoménica. No entraremos aquí en la discusión epistemológica entre Kant y Hegel, basta señalar que éste último intenta mostrar, siguiendo a Kant, que todo nuestro acceso a los objetos se haya mediado por la actividad de la razón, pero en contra del filósofo de Köninsberg, complementa esta afirmación señalando que la razón de la que habla no condiciona los objetos desde una serie limitada de categorías resguardadas a priori en un sujeto trascendental, sino que el pensamiento constituye las condiciones que le dan "objetividad" al mundo en el proceso mismo en que el sujeto intenta aprehender los objetos. Ahora bien, Hegel intenta superar la contradicción epistemológica en la que se contrapone la existencia de un mundo objetivo compartido y la remisión de las condiciones de posibilidad de la experiencia a la interioridad del sujeto, mostrando que esas condiciones se constituyen desde siempre en un proceso intersubjetivo, en la vida "espiritual". Con ello, intenta superar los dualismos entre interioridad y exterioridad y sujeto-objeto que, para él, subyacen a la filosofía de Kant. Así, en Hegel, la experiencia del mundo y las condiciones de su constitución se generan en la incesante relación que el sujeto -entendido como la infinita actividad intersubjetiva del hombre- tiene con el mundo. Esta idea se resume magistralmente en la hiperconocida afirmación del alemán que dice: "Según mi modo de ver, que deberá justificarse solamente mediante la exposición del sistema mismo, todo depende de que lo verdadero no se aprehenda y se exprese como sustancia, sino también y en la misma medida como sujeto" (Hegel, 1966, 15). No ahondaremos sobre la comprensión o incomprensión de Marx sobre Hegel, basta con mencionar que el primero intenta recuperar la posición hegeliana que le atribuye un papel esencial al proceso dialéctico, pero pretende ir más allá señalando que la objetividad no se constituye únicamente en el mundo del pensamiento, sino en la actividad práctica. En la segunda tesis sobre Feuerbach, Marx deja esto claro: "El problema de si al pensamiento humano se le puede atribuir una verdad objetiva no es un problema teórico, sino un problema práctico. Es en la práctica donde el hombre tiene que demostrar la verdad, es decir, la realidad y el poderío, la terrenalidad de su pensamiento. El litigio sobre la realidad o irrealidad de un pensamiento aislado de la práctica es un problema puramente escolástico".
} 
conciencia de su autodeterminación puede considerarse pensamiento libre ${ }^{27}$. Finalmente, como ya hemos señalado, Foucault afirma que en el texto titulado “¿Qué es la ilustración?”, el autor de la Crítica de la razón pura lleva a cabo una vinculación entre la autodeterminación de la razón y el análisis histórico del presente ${ }^{28}$. Así, la labor crítica es entendida, a la vez, como un análisis de las condiciones que posibilitan nuestra experiencia y como un proceso de liberación plenamente ligado a la toma de conciencia del desarrollo histórico que permite la autodeterminación de la razón.

Comparemos ahora tales características con el proyecto de nuestro filósofo. Foucault caracteriza su filosofía como un análisis de las condiciones históricas de nuestra constitución subjetiva, dicho análisis tiene la finalidad de evidenciar la serie de relaciones de poder que condicionan nuestra libertad ${ }^{29}$. En ese sentido no cabe la menor duda que su

\footnotetext{
${ }^{27}$ Sin duda, este es el sentido general de la filosofía práctica de Kant. El alemán cree poder mostrar que sólo se puede hablar del hombre como sujeto libre, si éste es capaz de darse a sí mismo las leyes de su acción. Pero para que estas leyes sean absolutamente libres, no deben proceder ni de un designio divino, ni de la naturaleza, sino de su propia legislación. La libertad del sujeto supone la posibilidad de que él se autodetermine, dándose las normas de su actividad en el mundo a partir del único elemento que es propiamente humano: la razón. Por su parte, Hegel en la Fenomenología del espíritu pretende mostrar que el "espíritu" es absolutamente libre porque logra superar las limitaciones que le impone la naturaleza "asumiéndola" y haciéndola suya. Es, pues, él y sólo él, el factor determinante en la construcción del mundo inteligible en el que interactuamos. De la misma manera, Marx muestra que la objetividad es el resultado de la acción práctica del hombre en el mundo. En su caso, se enfatiza el papel de la actividad productiva como medio simultaneo de apropiación y determinación del mundo. Marx acentúa algo que ya se encontraba en Kant y Hegel, el hecho de que los individuos y las colectividades que habitan el mundo sólo pueden adquirir su verdadera libertad cuando logran desasirse de las fuerzas externas que limitan su actividad práctica real. Kant y Hegel confiaban en el papel del derecho para superar, en la vida práctica, la condición de tutela en que los hombres vivían; por lo mismo, ambos consideraron que la revolución francesa fue un hecho capital para la humanidad, aunque los dos criticaron las violentas consecuencias de tal acontecimiento. Los dos pensadores alemanes coinciden en que el valor supremo de la revolución, consistió en manifestar que los hombres pueden ser considerados iguales frente al derecho, es decir, que no pueden ser sojuzgados ni obligados por nada excepto por la propia razón plasmada en un documento constitucional. Sin embargo, Marx va más allá, él muestra que la "alienación" del hombre, o lo que es lo mismo, su sujeción a fuerzas externas, no se limita a la falta de reconocimiento jurídico, sino que supone un entramado de relaciones de mayor complejidad, las cuales inscriben al hombre en un tipo de relación social en la que el producto de su trabajo se vuelve ajeno al trabajador.

${ }^{28}$ Este elemento es retomado y reelaborada por Hegel y Marx. La vinculación entre una filosofía crítica y el análisis histórico es, quizá, la marca de garantía de estos dos últimos filósofos.

${ }^{29}$ Más adelante ahondaremos en el concepto de libertad en la obra de Foucault, sin embargo debemos apuntar que contrariamente a las interpretaciones más triviales que se hacen de nuestro autor, el tema fundamental del
} 
trabajo se adscribe al proyecto crítico; sin embargo, vale la pena precisar cuáles son las peculiaridades que le dan especificidad a su trabajo y lo vuelven un referente central para la filosofía contemporánea.

En uno de sus últimos textos fechado en 1984, Foucault menciona que la intención general de su proyecto ha sido realizar "una Historia crítica del pensamiento"30. Un año antes, en el marco de una revisión general de su filosofía, señala: “[...] lo que procuré hacer es una historia del pensamiento. Y al hablar de 'pensamiento' hacía alusión a lo que podríamos llamar focos de experiencia" (Foucault, 2010, 19). De forma consciente, Foucault incluye dos conceptos de alta resonancia filosófica al momento de caracterizar su proyecto como un proyecto crítico; a saber, pensamiento y experiencia. A nuestro entender, la única manera de adentrarnos seriamente en la propuesta teórica de Foucault consiste en desentrañar el significado de los mismos y explicar el sentido de su vinculación.

En primer lugar, debemos decir que Foucault define pensamiento como "[...] el acto que plantea, en sus diversas relaciones posibles, un sujeto y un objeto" (MF, 999) y añade que una historia crítica del pensamiento, tiene la función de llevar a cabo "un análisis de las condiciones en que se han formado o modificado ciertas relaciones entre sujeto y objeto" (MF, 999). Nuestro autor no comprende el término "pensamiento" como aquella facultad interna a la conciencia que tendría por función aprehender objetos que le son externos, sino como el proceso en el que se ponen en contacto un sujeto y un objeto, los cuales en sí mismos y aislados carecen de toda determinación. Analizar el pensamiento no es, desde

francés no es otro que la libertad. Al final del texto “¿Qué es la Ilustración?” escrito en 1984, Foucault caracteriza la filosofía que él ha llevado a cabo como "[...] una labor paciente que da forma a la impaciencia por la libertad" (QI, 990).

${ }^{30}$ (Cfr, MF, 999). 
esta perspectiva, describir o clasificar las operaciones de la conciencia, ni indagar la naturaleza interna de las cosas, sino mostrar cuales son las condiciones efectivas que hacen posibles ciertas relaciones entre objeto y sujeto. La definición foucaultiana de "pensamiento" implica que éste adquiere significado en una relación incesante, la cual no se da entre elementos estáticos, sino entre factores que se constituyen mutuamente en el proceso de su actividad histórica. De ahí que una historia crítica del pensamiento deba indagar las condiciones que hicieron posible que ciertas disposiciones subjetivas pudieran vincularse con ciertos objetos, transformándose y determinándose a sí mismas en ese momento, y viceversa, que ciertos objetos pudieran determinarse al entrar en contacto con formas de subjetividad.

Así, en lugar de asumir la existencia del dualismo sujeto-objeto para centrar el estudio en las determinaciones de cualquiera de ambos polos, Foucault decide analizar lo que llama formas de “subjetivación” y “objetivación”; es decir, el proceso mediante el cual los sujetos y los objetos se determinan. Su particular forma de trabajar lo obliga a analizar la relación de constitución recíproca entre sujeto y objeto: “[...] el sujeto y el objeto no se constituyen uno y otro sino bajo ciertas condiciones simultaneas, pero en las que, a su vez, no dejan de modificarse el uno con relación al otro, y por tanto de modificar [su] campo de experiencia" (MF, 1002). Por lo mismo, la empresa del francés no puede partir unilateralmente de ninguno de los dos procesos -subjetivación, objetivación, pues esto implicaría asumir la existencia de un sujeto previo a su relación con los objetos, o de un objeto previo a su encuentro con los sujetos. De ahí que, en vez de partir de un objeto para mostrar su realidad esencial o indicar lo que éste debería ser si se adecuara a su verdadera forma, decide analizar el desarrollo que lo constituye y, al constituirlo, lo define como objeto. De igual forma con el sujeto, lejos de pretender encontrar las condiciones universales de su experiencia, decide analizar 
el proceso de su constitución, el cual sólo puede explicarse en su relación con los procesos de objetivación $^{31}$ :

Hace falta dar la vuelta a la marcha filosófica de remontada hacia el sujeto constituyente al que se le pide dar cuenta de lo que puede ser todo objeto de conocimiento en general; se trata, más bien, de volver a descender al estudio de las prácticas concretas mediante las cuales el sujeto se constituye en la inmanencia de un dominio de conocimiento. También al respecto cabe tener cuidado: rechazar el recurso filosófico a un sujeto constituyente no conduce a hacer como si el sujeto no existiera y a hacer abstracción de él en beneficio de

31 Por ejemplo, tomemos el caso de la locura. Para responder la pregunta ¿cómo es que la locura pudo considerarse una enfermedad mental en el siglo XIX?, la psiquiatría emergente acostumbraba a poner en relación dos acontecimientos fundamentales: en 1793 Pinel libera a los locos del encierro, por las mismas fechas Turke crea el primer hospital psiquiátrico. Tomando ambos sucesos se podía establecer un lazo explicativo capaz de mostrar cómo la liberación de los locos permitió desasirlos del estatuto de criminales con el que se los caracterizaba y calificarlos, por fin, como "enfermos". Con lo cual resultaba posible acceder a ellos en términos médicos. Según esta versión, hasta el siglo XVIII el erróneo estatuto con el que se los había investido hizo imposible observar que la esencia de la locura era su dimensión patológica ( $C f r$, OE, 320ss). Foucault piensa que esta lectura supone al menos una afirmación problemática, a saber: que los científicos del siglo XVIII desvelaron la esencia de la locura y, por lo mismo, el saber que detentan sobre ella puso ante nuestros ojos su verdad fundamental. Según esto, todos los discursos anteriores acerca de la locura, habrían estado imbuidos por el error, la ceguera, la sinrazón o, en el mejor de los casos, el desacierto. Si se hablaba de la locura en otro tiempo, si se le imponían límites, si se creaban normas, divisiones o discursos, incluso si se le admiraba o temía, era bajo el dictado de formas erradas, siguiendo los falsos caminos de la superstición y la ignorancia. Éste, sin embargo, era el obligado destino de todos los discursos acerca de la locura previos a la aparición de la psiquiatría, por un simple motivo: sólo ella fue capaz desentrañar el gran secreto que antes se le ocultaba a la razón; a saber, que la locura es, ante todo, un objeto médico. Foucault cree que este planteamiento es desacertado. No porque la psiquiatría carezca de un saber con contenido de verdad, ni porque crea que esa verdad es igual de "falsa" que las anteriores, tampoco porque considere "incompatibles" los criterios de verdad de distintas épocas, sino por la sencilla razón de que esta formulación supone que la verdad de la locura es la adecuación del pensamiento a un objeto siempre existente e inmutable. En vez de partir de la existencia del objeto "locura" o del sujeto "loco", para deducir sus rasgos fundamentales o la esencia de la enfermedad mental, Foucault prefiere indagar los procedimientos que posibilitaron la emergencia, tanto de la "locura", como del sujeto "loco", en términos de medicalización. Lo importante aquí, es comprender que la peculiar consideración de la locura como enfermedad mental, no pudo aparecer independientemente del proceso histórico que llevó a la configuración de ese saber peculiar que es la psiquiatría, y que la psiquiatría supone un proceso de medicalización del loco que no le es natural. No se trata, como bien dice Foucault, de afirmar que "la locura no existe", sino de indagar la forma de racionalidad que permitió la formación de un saber sobre la locura y que, en su formación, generó las determinaciones reales que constituyen lo que llamamos loco. Es decir, en vez de preguntarse por la verdad del loco, Foucault se pregunta por las condiciones de posibilidad que hicieron que, en un momento dado, ciertos sujetos entraran en un "juego de verdad" específico. Ahora bien, preguntarse por la locura en términos de juegos de verdad no significa sostener que la verdad no existe, ni caer en un relativismo radical, sino intentar ir un paso atrás y mostrar cuáles fueron las condiciones históricas que hicieron posible que nuestro pensamiento se acercara al sujeto loco en los términos de un saber científico que genera cierta normatividad y que obliga a los sujetos a reconocerse entre sí de una forma específica. Para decirlo en las palabras de Foucault, preguntarse por la locura en términos de juegos de verdad no es otra cosa que indagar cómo se "problematiza" la experiencia de la locura en un momento y un tiempo específico, para entender la serie de relaciones que constituyen su comprensión, su reconocimiento y las prácticas que la hacen posible. 
una objetividad pura; dicho rechazo tiene como mira hacer aparecer los procesos peculiares de una experiencia en la que el sujeto y el objeto "se forman y se transforman", uno por relación y en función del otro (MF, 1002).

Esto último nos permite dar un paso adelante. Tal como lo hemos señalado, el análisis foucaultiano pretende hallar las condiciones de aparición de nuestro pensamiento en el proceso que vincula al sujeto con el objeto. Ahora bien, una vez suprimida la vía de acceso a un sujeto puro sin relación con los objetos, o a un objeto inmutable e independiente de su relación con el sujeto, Foucault considera que el camino más pertinente para estudiar cómo se pone en relación un sujeto con un objeto en la historia efectiva es observar lo que se hace, es decir, las prácticas, entendidas como:

el conjunto de las maneras de hacer más o menos reguladas, más o menos reflexionadas, más o menos dotadas de finalidad, a través de las cuales se dibujan, a la par, lo que estaba constituido como real para los que buscaban pensarlo y gobernarlo, y la manera en que estos se constituían como sujetos capaces de conocer, de analizar y posiblemente de modificar lo real. Estas son las prácticas entendidas a la vez como modo de obrar y de pensar, que dan la clave para la constitución correlativa del sujeto y el objeto (MF, 1002).

Tomando en cuenta esta afirmación, podemos entender mejor a qué se refiere Foucault cuando asegura que su trabajo es una historia crítica del pensamiento -siempre que entendamos por pensamiento "el acto que pone en relación a un sujeto con un objeto" y no un conjunto de operaciones intramentales-. Veamos. Según el francés, aquello que "pone en relación" al sujeto con el objeto no es otra cosa que el conjunto de prácticas ${ }^{32}$ mediante las que constituimos el mundo en el mismo proceso en que nos constituimos como sujetos. Esta afirmación requiere una explicación minuciosa pues, a nuestro entender, posee un

\footnotetext{
32 Ya sea como prácticas discursivas, ya sea como tecnologías de poder, dispositivos de seguridad, procesos de gubenamentalización o tecnologías del yo, Foucault siempre intentó acceder al pensamiento desde la dimensión de lo que "se hace".
} 
valor teórico importante. En ella no sólo se debe leer el esfuerzo foucaultiano por delimitar el campo de estudio de su trabajo, también es posible observar una propuesta epistemológica de largo alcance. Analicémosla con detenimiento. La propuesta del francés se puede presentar de la siguiente manera: dado que no existe una subjetividad plenamente determinada antes de su vinculación con los objetos, ni una objetividad inteligible previa a la intervención del sujeto, la única forma de acceder al significado efectivo de nuestra experiencia consiste en observar aquello que pone en relación al sujeto con el objeto. La vinculación de ambos elementos se lleva a cabo por un pensamiento inevitablemente traducido en "actividad" o, para decirlo con Foucault, en las prácticas humanas. Pero el francés tiene claro que las prácticas no son el resultado unilateral de una acción desvinculada de toda reflexión teórica, evidentemente ellas no surgen de una espontaneidad arbitraria, sino que son el producto de un proceso reflexivo que se exterioriza en la realidad. Así, desde la perspectiva de Foucault, el "pensamiento" no es más que la infinita circularidad entre un obrar reflexionado y apropiado por el sujeto, y un sujeto que exterioriza esa apropiación; circularidad infinita en la que se constituye el sujeto en el mismo movimiento en que el mundo se determina.

Desde la Arqueología del saber, Foucault intentó avanzar en la comprensión de nuestra experiencia subjetiva mediante el estudio de las prácticas. En esa época, el francés intentaba analizar las prácticas discursivas para comprender la formación de ciertos saberes $^{33}$. Al dirigir el trabajo teórico en esta dirección, lograba romper el espacio cerrado de la conciencia para explicar el complejo proceso de aparición de las ciencias ${ }^{34}$ en la relación activa que vincula a los sujetos con el mundo. Más adelante, Foucault amplió el

\footnotetext{
${ }^{33}$ (Cfr., AS, 309ss).

${ }^{34}$ (Cfr., AS, 307ss).
} 
rango de sus análisis incluyendo otras prácticas como las tecnologías, los dispositivos y las estrategias; a partir de ellas intentó dar razón de los procesos de formación de normas, relaciones de poder y dinámicas de "gubernamentalidad" sin remitir a las intenciones particulares de quienes ejercen el poder, o a relatos teleológicos que explican la aparición de ciertos procesos de formación subjetiva apelando a una necesidad histórica ${ }^{35}$. Ahora bien, adentrarse a la experiencia por el camino de las prácticas supone, al menos, dos ventajas epistemológicas: por un lado, el análisis logra traspasar el terreno limitado de una conciencia intramental -ya que ésta resultaba insuficiente para explicar satisfactoriamente los procesos de formación subjetiva- y, por el otro, asume que la experiencia subjetiva es, necesariamente, resultado de un desarrollo intersubjetivo. Esto por dos razones, en primer lugar porque no existen prácticas que se configuren absolutamente al margen de los otros y, en segundo, porque toda práctica supone una exteriorización del sujeto que, necesariamente, lo pone delante de otros sujetos ${ }^{36}$. A lo largo de todo su trabajo, Foucault

${ }_{35}^{35}(C f r ., \mathrm{MP}, 7 \mathrm{ss})$.

${ }^{36}$ En este sentido, Foucault realiza dos desplazamientos importantes, por un lado, al dirigir el análisis de la experiencia a las prácticas y no a la interioridad del sujeto se deslinda de la larga tradición de filosofías de la conciencia que va de Descartes a Sartre, pasando por pensadores como Kant y Husserl; por el otro, rehúye de cualquier empirismo ingenuo, pues no pretende hallar las determinaciones del mundo dirigiendo su mirada a las"cosas en sí mismas", independientes de cualquier mediación subjetiva. Quizá sin saberlo, nuestro filósofo retoma el camino que Hegel abrió para solucionar el dualismo entre exterioridad e interioridad, acentuado en la modernidad. De forma apresurada se podría resumir dicho dilema epistemológico de la siguiente manera, desde el momento en que, con Descartes, la certeza del saber se remite a la conciencia que el sujeto tiene de sí mismo, surge un problema epistemológico de difícil solución; a saber, si se asume que las condiciones que posibilitan el conocimiento de los objetos deben localizarse, en última instancia, en el "psiquismo", resulta difícil explicar cómo es que el sujeto entra en contacto con los objetos que conoce y con las otras subjetividades que pueblan el mundo [Un buen resumen de este problema puede leerse en el artículo de Habermas "Caminos hacia la destrascendentalización. De Kant a Hegel y vuelta atrás" (Habermas, 2007, $181 \mathrm{ss})]$. Este problema atraviesa la filosofía moderna desde Descartes hasta la quinta meditación cartesiana de Husserl, incluso si en la segunda formulación del "imperativo categórico" Kant esboza una vía de solución posible, los comentaristas tienden a afirmar que es Hegel quien logra establecer la salida más coherente y sistemática para dicho problema. Desde los escritos de Jena, el autor de la Fenomenología del espíritu recurrió a los elementos mediadores del lenguaje, el trabajo y el reconocimiento reciproco para superar la dicotomía entre interioridad y exterioridad, mostrando que, en tanto seres hablantes y actuantes, todos los contenidos de nuestra actividad nos vienen dados, desde siempre, por un lenguaje que nunca es privado y por un proceso de actividad que hace de la otredad una otredad asumida y reconocida. Así, las condiciones que hacen posible nuestro conocimiento y nuestra actividad práctica, no son condiciones localizables al interior 
exploró algunos de los procesos de mediación a través de los cuales el mundo objetivo se vuelve inteligible para el sujeto en el mismo momento en que él se constituye como tal. Ya sea como prácticas discursivas, tecnologías o dispositivos de poder, formas de gubernamentalidad o tecnologías del yo, el análisis del filósofo francés siempre se centró en el estudio de ese vínculo práctico que permite llenar de contenido nuestra experiencia.

Después de estas anotaciones, sólo nos resta clarificar el sentido que Foucault le da a la noción de experiencia para brindar una explicación más o menos completa de la estructura crítica del proyecto foucaultiano. Por experiencia, el francés no entiende, ni la transmisión de datos sensibles desde el mundo de las cosas hasta la conciencia, ni la percepción de objetos enmarcada por las intuiciones puras de espacio y tiempo y organizada por categorías pertenecientes a la subjetividad, ni el acceso de una intencionalidad pura a los objetos como resultado de una suspensión de la "mundanidad externa". Foucault no niega la definición clásica de experiencia entendida como la apropiación que el pensamiento hace de los objetos del mundo; pero, una vez que ha aclarado que la relación entre pensamiento y objeto es el resultado de una actividad de coodeterminación reciproca a través de las prácticas humanas, sólo puede concluir que la comprensión de nuestra experiencia pasa por el análisis de aquellas prácticas que hacen posible dicha coodeterminación. Ahora bien, esas prácticas son el resultado singular de una actividad que no es ni perenne, ni transhistórica; para dar cuenta de nuestra experiencia no basta estudiar las operaciones cognitivas que permiten el acceso a los objetos, ni el conjunto de reglas, más o menos sedimentadas, por las que nos hemos socializado; se requiere, a la par, llevar a cabo un análisis de la serie de prácticas que se transforman a lo largo del proceso histórico. Por ello,

de una subjetividad aislada del mundo, sino el resultado intersubjetivo de la mediación del lenguaje, el trabajo y el reconocimiento recíproco. 
el trabajo de Foucault estudia los mecanismos que le permiten al sujeto reconocer los objetos de la manera particular en que lo hace en un periodo histórico concreto, así como las transformaciones que afectan y determinan al propio sujeto en ese proceso de reconocimiento. De esta manera se entiende por qué el francés acepta que su trabajo es deudor de la filosofía de Kant, aunque también se comprende qué lo aleja de él. En última instancia, su quehacer crítico sigue siendo un análisis de las condiciones de posibilidad de la experiencia, sin embargo, el modo de tratar este problema lleva a nuestro autor al terreno de las prácticas que se desarrollan a lo largo del proceso histórico de formación de nuestra racionalidad, y no a una indagación de las condiciones de toda experiencia posible.

Consistentemente con su planteamiento epistemológico, Foucault afirma que existen tres dominios relacionales a los que accedemos en nuestra actividad práctica. Cada uno de estos dominios es caracterizado por él como un eje de la experiencia. Según el francés, existen tres ejes fundamentales; a saber, las relaciones con objetos mediante las que se produce saber (prácticas discursivas), la serie de relaciones que nos ponen en contacto con otros sujetos para estructurar sus conducta (tipos de normatividad: dentro de los que se encuentran casos específicos como las tecnologías de poder, las formas de gobierno y gubernamentalidad) y la relación con nosotros mismos (prácticas de sí o tecnologías del yo) $)^{37}$. Por ello, en El uso de los placeres aclara que entiende por experiencia "la vinculación en una cultura entre campos de saber, tipos de normatividad, y formas de subjetividad" (HS2, 8) ${ }^{38}$. Al afirmar que la experiencia es la vinculación de estos tres

\footnotetext{
${ }^{37}$ Habermas se sorprendería de lo cercana que es esta división a las formas de racionalidad que él propone.

${ }^{38}$ En la primera clase del curso de 1983, Foucault señala: "Al hablar de pensamiento hacía alusión a lo que podríamos llamar focos de experiencia, donde se articulan unos con otros: primero, las formas de un saber posible; segundo, las matrices normativas de comportamiento para los individuos, y por último, modos de existencia virtuales para sujetos posibles. Estos tres elementos -formas de un saber posible, matrices
} 
niveles "en una cultura", deja claro que ninguna de estas relaciones se encuentra "dada" de antemano. El trabajo de una historia crítica del pensamiento debe mostrar cómo y por qué, estos tres niveles emergen de la manera que emergen, cuál es su relación específica y qué determinaciones le otorgan al sujeto en una cultura específica. $\mathrm{O}$, para decirlo de otra manera, una historia crítica del pensamiento debe hacer inteligible lo siguiente:

a) Cómo es que ciertos objetos entran en el dominio de la verdad para los sujetos que enarbolan discursos con pretensiones de conocimiento. Ya que los objetos que aparecen en este dominio no preexisten ni pueden ser definidos a priori.

b) Cómo es posible que una serie de normas emerjan como normas efectivas que estructuran la actividad de los sujetos, pues estas no son anteriores al proceso histórico que las produce.

c) De qué manera el sujeto problematiza la forma en que moldeará su propia conducta, porque este proceso tampoco es uniforme ni transhistórico.

d) Finalmente, qué tipo de sujeto emerge cuando éste se vincula con esas formas de verdad, esa normatividad y esas técnicas de conducción de sí mismo.

Este último punto es crucial. Como se ve, el objetivo de analizar cada una de estas tres dimensiones, no es sostener una Teoría del conocimiento, ni una Teoría del poder, ni una Fundamentación axiológica, sino comprender nuestra subjetivación; es decir, el proceso que configura nuestra experiencia como sujetos . El propio Foucault deja clara la finalidad de sus investigaciones en un artículo escrito en 1978 titulado "Le sujet et le pouvoir". En él afirma: "Je voudrais dire d'abord quel a été le but de mon travail ces vingt dernières la articulación de esas tres cosas es lo que llamo, creo, 'focos de experiencia"' (GSO, 19). 
années. Il n'a pas été d'analyser les phénomenès de pouvoir ni de jeter les bases d'une telle analyse. J'ai cherché plutôt à produire une histoire des différents modes de subjectivation de l'être humain dans notre cultura [...] Ce n'est donc pas le pouvoir, mais le sujet, qui constitue le théme général de mes rechèrches" (SP, 1041-1042). Esta afirmación nos permite alejarnos de aquella interpretación que insiste en criticar a Foucault por defender una Teoría social que reduce la historia a procesos de dominación ${ }^{39}$, y, por el contrario, nos abre la puerta para comprender mejor el objetivo real de su trabajo; a saber, la realización de un análisis crítico de las condiciones que hacen posible la experiencia del sujeto.

Tomando en cuenta estas precisiones podemos entender con mayor claridad el conjunto de todo su pensamiento. Contrariamente a lo que comúnmente plantean algunos críticos, el francés no pasa del tema del saber al del poder y de éste a la ética de forma arbitraria. Tampoco sustituye una arqueología por una genealogía ${ }^{40}$ debido a que considere la primera como algo insuficiente y desechable. En cada uno de los periodo de su trabajo, hizo énfasis en uno de los ejes de lo que, a su entender, constituye nuestra experiencia como sujetos. En el primer caso, la naturaleza de su trabajo consistía en “[...] señalar cuáles eran las prácticas discursivas que podían constituir matrices de conocimientos posibles, estudiar en esas prácticas discursivas las reglas, el juego de lo verdadero y lo falso y en general, si se quiere, las formas de la veridicción" (GSO, 20). Es decir, se trataba de contestar qué desplazamientos fueron necesarios para que ciertos saberes pudieran ser planteados en términos de verdadero o no verdadero. Esto con la intención de dilucidar tanto las transformaciones que provoca en el sujeto la inserción al ámbito de la verdad de nuevos discursos, como la posición que éste debe tomar ante ellos. En ese sentido, Foucault afirma

\footnotetext{
${ }^{39}$ (Cfr., Honneth, 2009, 268ss); (Cfr., Habermas, 2010, 259ss).

${ }^{40}$ Esta interpretación es común a Honneth, Habermas y a Dreyfus y Rabinow.
} 
que su objetivo fue indagar "[...] cuáles han sido las condiciones [de la emergencia de una nueva forma de veridicción], el precio que, en alguna medida, ésta ha pagado, sus efectos en lo real y el modo en qué, ligando cierto tipo de objeto a diferentes modalidades del sujeto, dicha emergencia, ha constituido, para un tiempo, para un área y para individuos dados, el a priori histórico de una experiencia posible" (MF, 1000). Claramente, para nuestro filósofo el análisis de los "juegos de verdad” es, también, un análisis de la forma en que se determina el sujeto que entra en relación con ellos.

En el segundo eje de la experiencia:

la cuestión pasaba[...] por analizar, digamos, las matrices normativas de comportamiento. $\mathrm{Y}$ en ese caso el desplazamiento no consistió en analizar el Poder con mayúscula, y ni siquiera las instituciones de poder o las formas generales o institucionales de dominación, sino en estudiar las técnicas y los procedimientos por cuyo intermedio se pretende conducir la conducta de los otros. Es decir que intenté plantear la cuestión de la norma de comportamiento [...] (GSO, 20).

Lejos de deducir las condiciones de validez normativa que debe suponer toda actividad comunicativa, Foucault decide estudiar los procesos concretos de formación de normas en dominios bastante bien delimitados (el hospital psiquiátrico, la cárcel, la fábrica, la escuela, etc.). Ahora bien, el estudio de los procesos de constitución de nuestra normatividad, muestra que la aparición de ciertas normas efectivas es correlativa a la emergencia de ciertos comportamientos individuales o colectivos. Esto, como vimos, lo obliga a distanciarse de todo análisis que suponga la existencia de un sujeto preexistente a los procesos de normatividad efectiva y mostrar, por el 
contrario, que la norma y el sujeto normalizado ${ }^{41}$ son correlativos. Así, el estudio de nuestra normatividad es, también, una indagación de la formación de procesos de subjetivación específicos.

Por último, el eje de la ética. En este caso, a Foucault le interesa indagar la forma específica que debe darse el sujeto para poder tener acceso a la verdad, y para poder adecuarse desde sí mismo a una normatividad externa. Aquí, su preocupación no es analizar las matriz de conocimiento que inserta al sujeto en la dinámica de ciertas reglas de veridicción existentes, ni investigar el tipo de restricciones que moldean su subjetividad desde una normatividad externa, sino estudiar la manera en que -históricamente- el sujeto trabaja sobre sí mismo para adecuar su conducta a ciertos estatutos de verdad y ciertas formas de normatividad ${ }^{42}$.

Utilicemos el ejemplo de la locura. Foucault no aborda este fenómeno preguntándose quién es considerado legítimamente loco y quién no. Prefiere dar un paso atrás y formula el siguiente cuestionamiento: ¿Cómo se presenta la experiencia de la locura en una cultura como la nuestra?, o mejor: ¿De qué forma específica nuestra cultura problematiza la experiencia de la locura? Si seguimos las indicaciones anteriores, podemos señalar que la experiencia de este fenómeno en sus manifestaciones específicas, sólo se comprende si hacemos inteligible la relación de los sujetos con cierta forma de saber sobre la locura (vbg. la psiquiatría a partir de siglo XIX), la normatividad que ésta impone y la relación que una vez definido como objeto de saber y de cierta normatividad, el sujeto tiene consigo mismo. Un análisis crítico de la experiencia de la locura debe mostrar cómo se relacionan estos tres elementos entre sí y cómo, en su relación, constituyen formas de subjetividad y objetividad

\footnotetext{
${ }^{41}$ Foucault es heredero de la tradición epistemológica francesa representada por Bachelard y Canguilhem. De Bachelard retoma la idea de que la norma y el contenido de la misma son correlativas; de Canguilhem retoma el análisis de las normas al interior del proceso de constitución de las ciencias ( $C f r$, Le Blanc, 2004).

${ }^{42}$ Una explicación bastante clara y contundente sobre la división del proyecto foucaultiano en estos tres periodos, puede leerse en la "Introducción" de Historia de la sexualidad 2. El uso de los placeres (HS2, 911), en el artículo "Foucault" (MF, 999), en las primeras clases de los seminarios de 1979 (NB, 18ss), de 1983 (GSO, 17ss) y en el artículo ¿Qué es la Ilustración? (QI).
} 
relativas. La particular forma que este planteamiento nos presenta fue señalada por el propio Foucault en 1983:

Sea como fuere, ése fue el punto de vista que tomé para tratar de analizar, hace ya bastante tiempo, algo como la locura, no considerada en absoluto como un objeto invariante a través de la historia, y sobre el cual habría actuado cierta cantidad de sistemas de representaciones, de función y valor representativo variable [...] Significaba, en cambio, intentar estudiar la locura como experiencia dentro de nuestra cultura, retomarla, en primer lugar, como un punto a partir del cual se constituía una serie de saberes más o menos heterogéneos, y cuyas formas de desarrollo había que analizar: la locura como matriz de conocimientos, de conocimientos que pueden ser de tipo propiamente médico, y también de tipo específicamente psiquiátrico o de tipo psicológico, sociológico, etc. En segundo lugar, la locura, en tanto y en cuanto es forma de saber, era también un conjunto de normas, unas normas que permitían recortarla como fenómeno de desviación dentro de una sociedad, y al mismo tiempo normas de comportamiento de los individuos con respecto a ese fenómeno de la locura y con respecto al loco, un comportamiento tanto de los individuos normales como de los médicos, el personal psiquiátrico, etc. Tercero y último: estudiar la locura en la medida en que esa experiencia de la locura define la constitución de cierto modo de ser del sujeto normal, frente y con referencia al sujeto loco. Fueron esos tres aspectos, esas tres dimensiones de la experiencia de la locura (forma de saber, matriz de comportamientos, constitución de modos de ser del sujeto), los que, con mayor o menor éxito y eficacia, procuré unir (GSO, 19).

Esta es, pues, la intención general del proyecto de Foucault. Habermas y Honneth se equivocan al caracterizar el trabajo del francés como una "crítica de la modernidad",43. Contrariamente a lo planteado por ellos, ni el Poder es el tema central del proyecto foucaultiano $^{44}$, ni su objetivo principal es fundar una Teoría del poder ${ }^{45}$ o una Teoría social

\footnotetext{
${ }^{43}$ (Cfr., Honneth, 2009, 125ss); (Habermas, 2008 A, 15).

${ }^{44}$ Honneth interpreta la preocupación de Foucault por el tema del poder como un desplazamiento que dirige su trabajo de la preocupación por las ciencias, a una Teoría de la dominación: "La teoría acerca de los conocimientos y saberes deviene teoría de la dominación" (Honneth, 2008, 235).

45 "Avons-nous besoin d'une théorie du pouvoir? Puisque toute théprie suppose une objectivation préalable, aucune ne peut servir de base au travail d' analyse. Mais le travail d'analyse ne peut se faire sans une
} 
sustentada en la idea de dominio. El francés quiere hacer algo totalmente distinto; a saber, análisis críticos muy bien delimitados de "focos de experiencia" específicos para comprender algunas formas de subjetivación. Tanto en Crítica del agravio moral ${ }^{46}$, como en Crítica del poder ${ }^{47}$ Honneth se esfuerza por mostrar que el proyecto de Foucault y el de Adorno comparten la intención de "hacer una crítica de la modernidad europea". Previamente Habermas había interpretado el proyecto foucaultiano de manera semejante, afirmando que el autor de Vigilar y castigar realiza una crítica que reduce la modernidad a un proceso universal de cosificación y dominio del sujeto: "Horkheimer y Adorno describieron el proceso de esta subjetividad que se abruma a sí misma de exigencias y se cosifica en términos parecidos a los de Foucault, como un proceso histórico universal" (Habermas, 2010, 341). Sin embargo, el autor de El nacimiento de la clínica se desmarca de trabajos como Dialéctica de la Ilustración, porque considera que este esfuerzo retoma el proceso de racionalización de la modernidad en su conjunto, mientras que él desea simplemente interrogar la formación de ciertas experiencias particulares:

Sans doute est-il plus sage de ne pas envisager globalment la rationalitation de la société ou de la cultue, mais plutôt d'analyser le processus dans plusieurs domaines, dont chacun renvoie à une expérience fondamentale : la folie, la maladie, la mort, le crime, la sexualité, etc.

Je pensé que le mot «rationalisation» est dangereux. Ce qu'il faut faire c'est analyser des rationalités spécifiques plutôt que d'invoquer sans cesse les progres de la rationalisation en général $(\mathrm{SP}, 1044)$.

conceptualization des problems traits. Et cette conceptualization implique une pensée critique -une verification constante (SP, 1042).

${ }^{46}$ (Cfr., Honneth, 2009 A, 125ss) El título del artículo ya es de suyo sugerente "Adorno y Foucault: Dos formas de una crítica a la modernidad".

${ }^{47}$ (Cfr., Honneth, $\left.2009 \mathrm{~B}, 267 \mathrm{ss}\right)$. 
Para bien o para mal, nuestro filósofo no desea hacer un diagnóstico general de "la razón moderna"48, ni establecer los fundamentos de una Teoría social ${ }^{49}$. Debido a ello, el aparato metodológico-conceptual que se da para afrontar sus preocupaciones es radicalmente distinto al que se daría quien intentara llevar a cabo estos objetivos. A lo largo de su vida Foucault no intentó fundar una Teoría social capaz de diagnosticar los problemas de "la modernidad", tampoco creyó posible hallar la piedra de toque de las "patologías" que aquejan al presente señalando el "desgajamiento", la "distorsión" o la "usurpación" de una forma de racionalidad sobre otra. Nada más ajeno al trabajo del francés que estas formas de proceder, durante casi treinta años nuestro pensador se dedicó a realizar análisis que, por su forma metodológica, deben ser caracterizados como arqueologías de distintos focos de experiencia ${ }^{51}$. Por lo mismo, dichos análisis no pueden ser juzgados ni

\footnotetext{
${ }^{48} \mathrm{Al}$ respecto Foucault dice: "[hay que] rechazar lo que de buen grado llamaré el chantaje de la Aufklärung [...] es preciso rechazar todo cuanto se presente bajo la forma de una alternativa simplista y autoritaria: o se acepta la Aufklärung, y se permanece en la tradición de su racionalismo [...] o se crítica la Aufklärung y entonces se intenta escapar de estos principios de racionalidad" (QI, 984).

${ }^{49}$ Es por ello que Sergio Pérez señala con acierto que el proceder del francés "[...] no debe tomarse como equivalente de una teoría social alternativa. En ella no hay ningún esfuerzo ni se ha dotado de los medios conceptuales para ofrecer su propia explicación global de la sociedad, sea esta estructuralista, funcionalista u otra. Foucault no pertenece al grupo de filósofos que, para confirmar sus doctrinas, ofrecen narrativas generales de la sociedad (Leyva, 2005, 387).

50 "El potencial de la razón comunicativa queda, a la vez, desplegado y distorsionado en el curso de la modernidad capitalista" (Habermas, 2010, 306).

${ }^{51}$ Honneth se equivoca al señalar que existe una ruptura entre el proceder arqueológico y el genealógico. El alemán parece interpretar, al igual que Habermas, que el paso a la genealogía le permite alejarse de las aporías de su arqueología para poder sostener una Teoría social (Cfr., Honneth, 2009 B, 267ss). En el interesante texto "Qué quiere decir hablar...y lo que puede hacer. Poderes del lenguaje y el lenguaje del poder" (Cusset, Haber (dir.), 2007, 149ss) Ives Cusset muestra algunos de los errores de lo que llama "la soberbia crítica de Honneth" a Foucault señalando, entre otras cosas, que la genealogía no supone una superación de los fracasos arqueológicos. Incluso en sus últimos textos, Foucault sigue sosteniendo que su forma de proceder es "arqueológica" (al respecto véase el texto titulado "Foucault", fechado en 1984 (MF, 999ss), el cual caracteriza las elecciones metodológicas como parte de una "arqueológia”; el texto "¿Qué es la Ilustración?" (QI, 975ss) escrito en los mismos años, el cual especifica con claridad que su crítica es "arqueológica en su método"). Esto es así, porque para ese entonces, Foucault tiene bastante claro que la arqueología no es otra cosa que la forma metodológica de su proceder crítico-filosófico. Forma metódológica que consiste en no buscar una instancia trascendental o semitrascendental capaz de determinar las condiciones de posibilidad universales para la legítima elaboración de un juicio, sino en intentar hallar, dentro de los mismos procesos históricos, las constantes mediante las que se pueden inferir las condiciones de posibilidad de nuestra experiencia, las condiciones que hacen aceptable que en una época dada emerjan ciertas formas de saber, ciertos normas y ciertas prácticas del individuo sobre sí mismo. Por ello, Foucault señala que su crítica es
} 
minusvalorados, como constantemente se hace, por no cumplir las pretensiones que exige

una Teoría social o un trabajo de fundamentación normativa.

\title{
1.3.- El papel de la problemática del poder en el proyecto general de una historia crítica del
}

\author{
pensamiento
}

\begin{abstract}
"Arqueológica -y no transcendental- en el sentido de que no buscará identificar las estructuras universales de todo conocimiento o de toda acción moral posible, sino que tratará a los discursos que articulan lo que pensamos, decimos y hacemos como eventos históricos" (QI). Ya desde la Arqueología del saber Foucault establece los dos elementos que singularizan el proceder de su trabajo: por un lado, la arqueología supone un desplazamiento del eje de la conciencia en beneficio de las prácticas: "En lugar de recorrer el eje concienciaconocimiento-ciencia (que no puede ser liberado del índice de la subjetividad), la arqueología reconoce el eje práctica discursiva-saber-ciencia"(AS, 307); y por el otro, decide centrarse en el proceso de formación de los objetos del discurso y no en la fundamentación de criterios de verdad. En el primer caso, se trataba de superar la dificultad que suponía analizar la emergencia de ciertas formas de conocimiento desde la perspectiva unilateral de los procedimientos que la conciencia debe realizar para alcanzar la verdad, para resaltar los sucesos históricos que sirven para explicar la emergencia de las ciencias. Esto suponía dirigirse no ya a la conciencia como medio de explicación del surgimiento del conocimiento, sino a las prácticas discursivas que constituyen formas de saber dentro de las que el sujeto se encuentra siempre presente y en donde halla la verdad. Dice Foucault en La arqueología del saber: "Y mientras la historia de las ideas encuentra el punto de equilibrio de su análisis en el elemento del conocimiento (hallándose así obligada, aun en contra suya, a dar con la interrogación trascendental), la arqueología encuentra el punto de equilibrio de su análisis en el saber, es decir en un dominio en el que el sujeto está necesariamente situado y es dependiente, sin que pueda figurar en él jamás como titular (ya sea como actividad trascendental, o como conciencia empírica)" (AS, 307). Este descentramiento del eje de la conciencia, fue dirigido -en el periodo en que Foucault enfatizó el campo del saber- hacia el problema de las ciencias, y con ellas, a las prácticas discursivas que las configuraban, pero en el desarrollo posterior de su trabajo este desplazamiento se transforma en un principio metodológico que dirige su reflexión ya no sólo al mero análisis de las prácticas discursivas, sino a las prácticas en sentido amplio, entendidas "como el conjunto de las maneras de hacer más o menos reguladas, más o menos reflexionadas, más o menos dotadas de finalidad, a través de las cuales se dibujan, a la par, lo que estaba constituido como real para los que buscaban pensarlo y gobernarlo, y la manera en que estos se constituían como sujetos capaces de conocer, de analizar y posiblemente de modificar lo real. Estas son las prácticas entendidas a la vez como modo de obrar y de pensar, que dan la clave para la constitución correlativa del sujeto y el objeto" (MF, 100). En el segundo caso se trataba de afirmar que, para ser fiel a su propio objetivo, la arqueología debía indagar la propia formación de nuestros objetos de conocimiento, observando las regularidades de ciertas prácticas discursivas sin partir del análisis previo de la legitimidad de los criterios. En ese sentido podemos afirmar que la arqueología no es un periodo pasajero del proyecto foucaultiano, sino la forma de proceder que atraviesa todo su trabajo. Ella requiere examinar las condiciones históricas de "aceptabilidad" de los discursos y las prácticas, partiendo de una elección metodológica que tiene por virtud no predeterminar los análisis asumiendo el resultado de los procesos de subjetivación y objetivación -el loco, el delincuente, la psiquiatría, etc.- como el punto de partida o el anclaje a partir del que pudiéramos deducir condiciones legítimamente universales. Lejos de iniciar nuestro acercamiento a procesos históricos particulares con un repertorio de criterios normativos aptos para juzgar esa situación desde la perspectiva del observador externo, la metodología foucaultiana intenta desentrañar la constitución misma de los procesos en que se entrecruzan discursos de verdad, relaciones de poder y procesos de subjetivación, a través de un análisis inmanente de las condiciones de su emergencia.
\end{abstract}


Hay que insistir sobre este punto. Habermas y Honneth pueden sostener que el francés realiza una crítica que reduce el desarrollo de la modernidad a la proliferación de relaciones de poder sólo porque previamente han "universalizado" los resultados singulares que Foulcault obtiene de ciertas formas de experiencia particulares. Sin embargo, esta confusión se disuelve si tomamos en cuenta las revisiones finales que Foucault hace de su propio trabajo. En efecto, tal como hemos apuntado a lo largo de este texto, el proyecto foucaultiano puede definirse correctamente como una historia crítica del pensamiento destinada a comprender nuestra experiencia como sujetos. Ahora bien, la labor del francés no pretende dar razón de la experiencia del sujeto moderno en su totalidad por dos motivos. En primer lugar, porque no tiene mucho sentido hablar de "un" sujeto moderno -como si las determinaciones del hombre fueran unitarias en todos los ámbitos-. En segundo lugar, porque la exigencia epistemológica de acceder a la experiencia por la vía de las prácticas nos muestra que, a prácticas distintas, corresponden formas de subjetividad distintas. Tanto por las especificaciones teóricas de su filosofía, como por convicciones personales, Foucault se opuso durante toda su vida a esas grandes explicaciones totalizantes que, ingenuamente, creían poder agotar la esencia del hombre o el quid de toda nuestra modernidad. Ante este tipo de formulaciones el autor de Vigilar y castigar siempre trató de contraponer ejercicios locales, muy bien delimitados, de experiencias concretas. El importante texto titulado "Foucault" escrito en 1984 por el francés y firmado bajo el pseudónimo de Maurice Florence, nos da una clave fundamental para comprender el carácter y la circunscripción de sus trabajos. Luego de trazar las líneas generales de su proyecto y mostrar sus límites y alcances, agrega con claridad: 
Ahora bien esta cuestión -o esta serie de cuestiones- que son las de una "arqueología del saber" Michel Foucault no la ha planteado, ni quería hacerlo sobre cualquier juego de verdad. Antes bien, lo ha hecho sólo sobre aquellos juegos en los que el sujeto se plantea como objeto de saber posible; cuáles son los procesos de subjetivación y objetivación que hacen que el sujeto pueda llegar a ser, en tanto sujeto, objeto de conocimiento" (MF, 1000).

Foucault no intenta generar una explicación de la modernidad y, mucho menos, reduce su complejidad al desarrollo de relaciones de poder por una sencilla razón: su trabajo se circunscribió al análisis de un tipo de formación subjetiva, aquella en la que los sujetos se transforman en objeto de estudio. Afirmar que, para el francés, "la modernidad" puede explicarse únicamente bajo el paradigma del poder es no comprender la intención de su trabajo. Esta conclusión es el resultado de extender a nivel de "Teoría social" una serie bien delimitada de análisis concretos dirigidos a ciertos tipos de experiencia. Habermas y Honneth yerran en este punto. En ambos resulta fácil encontrar afirmaciones como ésta: "Al igual que la Dialéctica de la ilustración, también la crítica de Foucault a la era moderna tiene en su centro la experiencia de un crecimiento inaudito del poder y de la violencia: viendo la historia de la emancipación $[\ldots]$ arrojada a la corriente de un proceso único de extensión del poder" (Honneth, 2009A, 125) ${ }^{52}$. El momentáneo énfasis (1970 a 1979) que el francés puso en el tema del poder, es mal comprendido si se entiende en los términos de una Teoría social. En cambio, puede ser valorado de forma adecuada si se le valora como un punto de paso obligado, como un elemento necesario en un trayecto filosófico que, por distintos motivos, pone especial atención en aquellas formas de

\footnotetext{
${ }^{52}$ Es imposible afirmar que este tipo de sentencias no representan errores mínimos o equivocaciones de un argumento mucho más sólido. Todo lo contrario, son el núcleo de la crítica que estos autores dirigen a Foucault.
} 
subjetivación en las que los sujetos adquieren sus determinaciones bajo la condición de ser objetivados.

En efecto, después de explicar que su trabajo se centra exclusivamente en aquellas experiencias en las que el sujeto es objetivado para un saber posible, Foucault agrega: "desde el momento en que a través de dichas prácticas se trata de estudiar los diferentes modos de objetivación del sujeto se comprende la parte importante que al respecto ha de ocupar el análisis de las relaciones de poder" $(\mathrm{MF}, 1002)^{53}$. El oriundo de Poitiers sostiene que las formas de subjetividad que suponen la objetivación del sujeto son más propensas a transformarse en relaciones de poder. Para comprender adecuadamente este elemento, vale la pena explicar semejante vínculo. En el siguiente apartado analizaremos a profundidad las dificultades que el concepto de poder conlleva al momento de abordar los textos de nuestro autor. Por ahora, resulta suficiente afirmar que Foucault no entiende por poder la acción irracional de una fuerza que opera "a nuestras espaldas", ni la instrumentalización del hombre, ni, mucho menos, la "ilegítima" intervención de una racionalidad teleológica en los terrenos que legítimamente le pertenecerían a la racionalidad comunicativa; sino la actividad racional por medio de la cual se estructura el campo de posibilidades de las acciones de los otros para dirigir sus conductas ${ }^{54}$. La noción de poder no tiene la función de desenmascarar la "falsedad" de nuestros saberes, ni pretende denunciar las prácticas que "ilegítimamente" instrumentalizan o cosifican al hombre, únicamente nos permite entender una forma de acción racional particular que se caracteriza por inducir las acciones de los otros: “[...] no hay que efectuar la separación de la legitimidad, no hay que señalar el punto

\footnotetext{
${ }^{53}$ Habermas de nuevo se equivoca cuando interpreta que en Las palabras y las cosas Foucault crítica las ciencias humanas desde la herencia heideggeriana de una crítica a la metafísica del sujeto.

${ }^{54}$ (Cfr., SP, 1053ss).
} 
de error y de la ilusión [...] el término de poder [...] no hace otra cosa que recubrir [recouvrir] toda una serie de mecanismos particulares susceptibles de inducir comportamientos"(QC, 27).

Ahora bien, Foucault cree, con razón, que las prácticas que funcionan mediante un saber capaz de objetivar al sujeto, pueden insertarse fácilmente en aquellas tecnologías que tienen como objetivo conducir a los hombres hacia ciertos fines (tecnologías de poder). Esto porque, al hacer del sujeto el objeto de un saber posible, los resultados de dicho saber no sólo describen una realidad, sino que pueden servir como formas prescriptivas destinadas a guiar las conductas de los otros. Así, se ve con claridad que el supuesto fracaso de la arqueología del saber ${ }^{55}$ no explica el arribo de Foucault al problema del poder, sino la cercanía existente entre aquellos saberes que obtienen un tipo de conocimiento al objetivar al sujeto, y la posible utilización de ese conocimiento para dirigir la conducta de los hombres. Debemos ser cautelosos en este punto para evitar malos entendidos: afirmar que la objetivación del sujeto puede inscribirse en tecnologías de poder, no es afirmar que toda objetivación del sujeto es, necesariamente, una práctica de poder; tampoco equivale a decir que todo saber sobre el sujeto es una forma de poder ${ }^{56}$.

\footnotetext{
${ }^{55}$ La hipótesis que sostiene que la genealogía es el resultado de la arqueología del saber, es ampliamente defendida por Habermas y Honneth (Cfr., Habermas, 2010, 259ss); (Honneth, 2009 B, 168ss). En un lúcido artículo titulado "Sobre epistemología y arqueología de Canguillem a Foucault", Arnold I. Davidson desmiente esta hipótesis de manera definitiva (Cfr., Davidson, 2004, 282ss).

${ }^{56}$ De hecho, Foucault estudia este mismo problema -la objetivación del sujeto- desde la dimensión del saber en la primera etapa de su trabajo. En 1978, por ejemplo, hace un breve recorrido de su propio trabajo y deja claro que el tema fundamental de todos sus análisis ha sido el proceso de objetivación del sujeto (subjectivacion) desde tres perspectivas: "j'ai traité, dans cette optique, des trois modes de objectivation qui transforment les êtres humaines en sujets" (SP, 1042). En el primero de esos "modos", se trataba de analizar dicho problema indagando "Les differents modes d'investigation qui cherchent acceder au statut de sciencie; je pensé par example à la objectivation du sujet parlant en grammaire génerérale, en philologie et en linguistique. Ou bien, toujours dans ce premier mode, à la objectivation du sujet productif, du sujet qui travaille, en économie et dans l'analiyze des richesses. Ou, encoré, pour prendre un troisème exemple, à l'objectivation du seul fait d'être en vie en histoire naturelle ou en biologie (SP, 1042). Estos tres ejemplos son estudiados en Las palabras y las cosas, Foucault afirma que en dicho texto la temática de la objetivación
} 
Para Foucault, objetivar al hombre no es, sin más, una relación de poder, sólo puede considerarse como tal cuando se inscribe en un dispositivo racional que tiene la finalidad de dirigir las conductas de los otros por medio de ciertas prácticas específicas: "[le pouvoir] est un ensamble d'actions sur d'actions posibles [les relations de pouvoir sont] modes d'action plus ou moins réfléchis et calculé, mais tous destinès a agir sur les possibilités d'actions d'autres individus" (SP, 1056). De esta manera, observamos con claridad que la interpretación de Habermas y Honneth se encuentra lejos de la verdad. El análisis específico de las relaciones de poder, no sólo no debe confundirse con el análisis del sujeto moderno en su conjunto, sino que tampoco puede identificarse inmediatamente con el tipo de experiencia que objetiva a los sujetos. Las relaciones de poder son procesos de subjetivación demasiado específicos y bien diferenciados, que requieren un estudio minucioso incapaz de universalizarse. Tomemos el ejemplo de Vigilar y castigar, en este texto Foucault muestra, entre otras cosas, que la emergencia de la prisión como castigo generalizado $^{57}$ y la aparición de ciertas ciencias humanas en el siglo XIX, sólo se puede explicar si tomamos en cuenta el funcionamiento de un tipo peculiar de tecnologías de poder: las disciplinas ${ }^{58}$. Esto no quiere decir, como erróneamente se ha querido interpretar, que esas ciencias se vuelvan ilegitimas o falsas por ese motivo. Todo lo contrario, lo que el

\footnotetext{
del sujeto fue estudiada "En [...] relación con la aparición y la inserción, en ciertos ámbitos y según la forma de un conocimiento de estatuto científico, de la cuestión del sujeto que habla, que trabaja y que vive; de lo que se trataba entonces era de la formación de algunas de las «ciencias humanas» estudiadas con referencia a las prácticas de las ciencias empíricas y a su discurso particular en los SXVII y XVIII (Las palabras y las cosas)" (MF, 1000). Efectivamente, en Las palabras y las cosas Foucault tematiza la objetivación del sujeto, pero no lo hace desde la perspectiva de las relaciones de poder, sino con la intención de buscar las condiciones que hicieron posible que el hombre fuera insertado en el interior de ciertos discursos científicos. En todos los lugares en que el mismo autor realiza una retrospectiva de su trabajo no incluye este libro dentro del tema del poder, mientras que textos anteriores como El nacimiento de la clínica e Historia de la locura sí son remitidos a ese concepto. Esto se explica porque el problema del poder no se reduce a la objetivación del sujeto, más bien adquiere su verdadera especificidad en la conducción y la estructuración de las conductas de los hombres.

${ }^{57}$ (Cfr, VC, 233ss).

${ }^{58}$ (Cfr., VC, 139ss). Al respecto véase también: (Boullant, 2004, 63ss); (Gros, 2007, 83ss).
} 
francés señala es distinto; a saber, que la manera en que se logró hacer del hombre un objeto de análisis supuso, en esos casos, un cierto número de prácticas que estructuraron la conducta de los sujetos de tal forma que, de hecho, propiciaron su objetivación y su cientifización $^{59}$. Foucault no se cansa de afirmar que las relaciones de poder producen $\operatorname{verdad}^{60}$, el francés no pretende sostener una tesis relativista que niegue la existencia de criterios de verdad, como algunos críticos señalan ${ }^{61}$, ni afirma que, dado que en todos lados hay poder, cualquier argumento con pretensiones de verdad se nulifica. De hecho ante esta tipo de objeciones el autor responde:

Creo, en efecto, que a los ojos del púbico soy quien ha dicho que el saber se confunde con el poder, que aquél no era sino una fina máscara puesta sobre las estructuras de dominación y que estos eran siempre opresión, encierro, etc. Sobre lo primero responderé con una carcajada. Si hubiera dicho, o querido decir, que el saber era el poder, lo habría dicho y, habiéndolo dicho, no tendría nada que añadir, puesto que al identificarlos no veo porque me habría empeñado en mostrar sus diferentes relaciones. Precisamente me he esforzado por ver cómo ciertas formas de poder que eran del mismo tipo podían dar lugar a saberes extremadamente diferenciables en su objeto y en su estructura (OE, 1012).

Como veremos más adelante con mayor precisión, la incursión de Foucault en el análisis del poder no tiene por objetivo negar la posibilidad del conocimiento, ni reducir al modelo de la lucha y la represión la multiplicidad de relaciones que constituyen la modernidad. Por el contrario, su preocupación respecto a la relación entre poder y saber tiene el objetivo de estudiar, a la vez, los mecanismos que en ciertas formas de experiencia, permiten que algunos saberes sirvan como instrumento para conducir las acciones de los otros, y el proceso de cristalización de aquellos discursos que surgieron en medio de ciertas estrategias

\footnotetext{
${ }^{59}$ (Cfr., Boullant, 2004, 84ss).

${ }^{60}$ (Cfr., VC, 34); (VFJ, 63ss).

${ }^{61}$ (Cfr., Honeth, 2009 B, 167ss).
} 
de poder -sin que esto indique que esos saberes y esos discursos sean necesariamente falsos o ilegítimos-. Sin lugar a dudas, las ciencias que en ciertos periodos históricos sirven para conducir a los hombres producen resultados verdaderos $\mathrm{y}$, de hecho, es por tal motivo que se las utiliza, pero siguen formando parte de una tecnología de poder en la medida en que son usadas para estructurar la actividad de los hombres. El problema que está en juego no es el de la falsedad o la verdad de un saber, ni el de la legitimidad de su funcionamiento, sino el de su contexto de acción y la finalidad de su ejercicio.

El error más común al momento de abordar el trabajo de Foucault, consiste en interpretar el problema de las relaciones de poder y saber desde la perspectiva de Habermas. Según el filósofo alemán, Foucault sostiene que todo saber es relativo porque está atravesado de relaciones de poder. De ahí que, para el francés, resulte imposible distinguir los discursos verdaderos de los falsos. A partir de este argumento, Habermas explica el recelo con que Foucault se acerca a las ciencias humanas. Según él, la postura del francés podría enunciarse de la siguiente manera: para que el sujeto llegue a ser objeto de conocimiento es necesario que, previamente, éste haya sido objetivado mediante la implementación de ciertas relaciones de poder, por lo mismo el saber que las ciencias humanas detentan es, siempre, resultado de acciones violentas. Así, según Habermas, Foucault concluiría que la aparente verdad que las ciencias humanas obtienen del hombre no es más que el resultado de un saber repleto de poder. A parir de esta interpretación, Habermas muestra que Foucault asume indebidamente la siguiente conclusión: la estructura de las ciencias humanas las hace presas ineludibles del poder y, por lo mismo, inválidas. 
Para mostrar la falsedad de esta suposición, el alemán afirma que es posible fundamentar la validez de un saber científico sobre el hombre sin hacerlo depender de relaciones de poder. Si esto es posible, el falso impasse foucaultiano quedaría saldado y su tesis refutada por completo. Es decir, si Habermas puede sostener que existen ciencias humanas que, en su estructura teórica, se encuentran libres de relaciones de poder, la postura del francés debería considerarse errónea definitivamente. Por ello, en el Discurso filosófico de la modernidad, el alemán se ufana de desenmascarar la confusión foucaultiana. Desde su perspectiva, el descubrimiento del paradigma de la razón comunicativa nos permite entender los procesos de objetivación del sujeto al margen de la violencia, la instrumentalización o la cosificación del hombre. El autor de Facticidad y validez sostiene que el paradigma de la acción comunicativa nos permite vislumbrar una solución al problema planteado por el oriundo de Poitiers. En efecto, Habermas afirma que la praxis comunicativa hace patente la posibilidad de tematizarnos desde la perspectiva de una tercera persona; esta posibilidad nos permite tener un acceso a nosotros mismos a partir de la perspectiva de un observador capaz de juzgarse desde la posición del otro. Si las nuevas ciencias comprensivas siguen ese paradigma, no tendrían porque explicar la autotematización del sujeto como el resultado necesario de relaciones de $\operatorname{poder}^{62}$.

Pero Habermas sólo puede afirmar que de esta manera evidencia la falsedad de la postura foucaultiana, porque antes ha asumido dos argumentos que ya hemos desechado: por un lado sostiene que, para el francés, toda objetivación del sujeto es, inmediatamente, una forma de poder, y por el otro, que la existencia de relaciones de poder hace imposible distinguir la validez de nuestros criterios de verdad. El filósofo de Frankfürt piensa,

${ }^{62}$ (Cfr., Habermas, 2010, 323). 
erróneamente, que la concepción de poder acuñada por Foucault es tan negativa que, además de remitir a una fuerza irracional, produce, inevitablemente, efectos de ilegitimidad, imposibilita la verdad e impide la fundamentación de toda normatividad. El autor de Vigilar y castigar, sin embargo, no plantea el problema de las relaciones entre saber y poder en esos términos, Foucault no sostiene que las ciencias humanas son ilegítimas, ni que los criterios de distinción entre lo verdadero y lo falso se disuelven al momento de inscribirse en relaciones de poder. Por el contrario, el trabajo realizado por el francés durante la década de los 70's tuvo un objetivo distinto, en ese periodo se trataba de comprender cómo se configuran y qué efectos tienen sobre los sujetos aquellas experiencias en las que, para dirigir sus conductas, son objetivados, insertados en campos de saber y en discursos con pretensiones de verdad. Ahora bien, el hecho de que esos discursos inserten al hombre en procesos de veridicción con el afán de dirigir sus conductas, no implica ni que los saberes sean falsos, ni una denuncia a priori respecto a la maldad o la iniquidad de esas experiencias. Los trabajos de Foucault únicamente intentan hacernos comprensibles ciertas formas de subjetivación que resultan particularmente importantes tanto por sus efectos, como por el hecho de que, como veremos, ponen en juego el problema de la libertad.

Pongamos un ejemplo. En el seminario de 1978 Foucault estudia las principales características de una nueva concepción de gobierno surgida en el siglo XVII: La razón de Estado $^{63}$. Después de la firma del tratado de Westfalia los Estados se vieron obligados a declinar sus ambiciones universalistas conformándose con participar en un sistema de competencia política inter-estatal. Así, todos los aparatos gubernamentales se enfrentaron a la necesidad de incrementar su capacidad productiva para no rezagarse ante los otros

${ }^{63}$ (Cfr., STP, 293ss). 
competidores. En ese contexto, el conocimiento de las características y el potencial interno de cada nación, resultaban absolutamente relevantes. La estadística solventó semejantes necesidades otorgando un análisis metódico ${ }^{64}$ de la población para que ésta fuera mejor gobernada. Este breve ejemplo es ilustrativo, sin duda la estadística surgió en el marco de un proyecto de conducción de los sujetos, pero no por ello podemos afirmar que sus resultados sean falaces, ni que por servir como instrumento de poder anule todo criterio de verdad. Todavía más, en ese contexto la estadística fue un instrumento de saber que permitió la creación de una serie de prácticas y mecanismos tendientes a dirigir a los otros (mecanismos de poder); no cabe duda que la aplicación de esas prácticas de gobierno influyó de forma decisiva en la experiencia que los sujetos se forjaron de sí mismos y de sus obligaciones y que, por lo mismo, su análisis resulta necesario si nos proponemos entender la gestación de ciertas formas de subjetividad.

Ahora bien, arriba apuntamos que el interés de Foucault respecto a las relaciones de poder nos reenvía de forma ineludible al espinoso tema de la libertad. En efecto, las formas de gobierno que se ponen en marcha gracias a los medios proporcionados por ciertos saberes, nos colocan, de una u otra forma, ante un hecho inminente: en todas las épocas los hombres se han resistido ante ciertas formas de poder. Es en esos procesos de resistencia que, según el francés, la libertad de los sujetos se arriesga y determina ${ }^{65}$. A filósofos como Habermas o Berman les sorprendería saber que, lejos de suprimir la libertad, la noción de poder es la rejilla de inteligibilidad que nos reenvía a ella de forma inevitable. En el siguiente capítulo,

\footnotetext{
64 "La teoría del arte de gobernar [...] estaba ligada a todo un conjunto de análisis y saberes que se desarrollaron desde fines de ese siglo y cobraron toda su amplitud en el siglo XVII, esencialmente el conocimiento del Estado en sus diferentes datos, sus diferentes dimensiones, los diferentes factores de su poder: justamente lo que se denomina 'estadística' como ciencia del Estado" (STP, 127).

${ }^{65}$ Sobre la relación entre poder y libertad en Foucault, véase: (SP, 1041ss); (OE, 1027ss).
} 
abordaremos con detenimiento la relación entre gobierno y libertad en el trabajo del francés, pero por ahora vale la pena señalar que el análisis de las formas de dirigir la subjetividad tiene la virtud de colocarnos, en el mismo golpe de vista, ante las formas de resistencia concretas que, en todo momento, los sujetos han ideado para salvaguardar su libertad. Así, contrariamente a los prejuicios que comúnmente se propagan sobre la filosofía del francés, ni el poder anula los criterios de verdad, ni cancela la posibilidad de la libertad. Todo lo contrario: la reafirma. Si los sujetos son capaces de resistirse a ciertas formas de sujeción, como de hecho lo hacen, es porque son libres, pero, como veremos más adelante, esa libertad sólo adquiere determinaciones reales en el contexto específico de su aparición efectiva.

En resumen, el trabajo del francés debe ser considerado como un análisis de las condiciones que hacen posible la experiencia del sujeto. Esta caracterización es pertinente únicamente si aceptamos que, por experiencia, no se entiende el mecanismo que le permite a la conciencia aprehender objetos auto-subsistentes, sino el resultado de un proceso históricopráctico en el que el sujeto y el objeto se determinan recíprocamente. Foucault piensa que una historia crítica del pensamiento, tiene el objetivo de ayudarnos a responder ¿quiénes somos nosotros en tanto sujetos inmersos en nuestro presente? Para llevar a cabo este objetivo, apuesta por analizar aquellas prácticas a través de las cuales, los sujetos se vinculan con el saber, con las normas y con ellos mismos ${ }^{66}$. En el marco general de ese proyecto, Foucault se limitó a analizar experiencias bastante concretas; a saber, aquellas en las que el sujeto adquiere sus determinaciones bajo la condición de ser planteado como

\footnotetext{
${ }^{66}$ Estos tres elementos son importantes: la relación del sujeto con el saber, genera los discursos verdaderos que reproducimos; la relación del sujeto con las normas, estructura el marco de nuestra conducta, y la relación del sujeto consigo mismo determina su acción personal.
} 
objeto de conocimiento. Por lo mismo no puede malinterpretarse su trabajo afirmando que intenta dilucidar las condiciones de la subjetividad moderna en su totalidad. Por último, durante un periodo considerable (la década de los setentas), nuestro autor se propuso estudiar la forma en que este tipo de experiencias genera relaciones de poder destinadas a conducir las conductas de los otros. Sin embargo, de la lectura de estos análisis concretos no se puede inferir que su proyecto sea relativista o determinista. Foucault no se propone negar la existencia de la verdad o cancelar la posibilidad de la libertad humana, sino que, por el contrario, acepta que hay criterios de verdad y asume que la libertad existe y se manifiesta históricamente en prácticas concretas.

Así, en estrecho vínculo con la tradición crítica iniciada por Kant, el trabajo de Foucault intenta mostrar las condiciones que hacen posible la constitución de nuestra experiencia. Sin embargo, su intención, como él mismo señala, no es "la búsqueda de estructuras formales que tienen valor universal, sino [la] investigación histórica a través de los acontecimientos que nos han conducido a constituirnos y a reconocernos como sujetos de lo que hacemos, pensamos y decimos" (QC, 986). En ese sentido, el francés toma distancia respecto a lo que aquí hemos llamado "filosofía Crítica en estricto sentido kantiano". Es verdad que Foucault es deudor de Kant en lo que respecta a la búsqueda de las condiciones de posibilidad de la experiencia, pero para él esta búsqueda no pretende hallar las estructuras formales que nos permitirían establecer criterios para juzgar la validez de nuestro proceder racional, tanto si consideramos que estos se obtienen del análisis de las condiciones formales del sujeto, como si consideramos, con Habermas, que acudir a la pragmática del lenguaje nos permitiría salir de las filosofías de la conciencia y generar criterios anclados en una dinámica intersubjetiva. Tampoco importa que esas estructuras 
sean consideradas condiciones válidas universalmente, o si, otra vez con Habermas, se afirman como reglas "irrebasables" surgidas de los procesos sociales. Los progresos alcanzados en la búsqueda de criterios formales para diferenciar el uso legítimo e ilegitimo de la razón, no son el objeto de un proyecto filosófico como el que Foucault se propone.

Conocemos de sobra la crítica que, desde una perspectiva normativa, se le puede hacer a un trabajo de estas características. Sin duda, se dirá que renunciar al sujeto y al objeto como puntos de anclaje para el análisis de las condiciones de la experiencia no implica la necesaria caída en un relativismo que niegue la posibilidad de hallar criterios con pretensión de universalidad. Se dirá, también, que la evolución de la filosofía desde el giro lingüístico hasta la pragmática formal, nos permite buscar dichos criterios en el lenguaje por su cualidad intersubjetiva. Lo que debemos aclarar es que Foucault no acude a estos elementos porque no es esa la intención de su trabajo. La filosofía del francés no pretende buscar criterios normativos, ni denunciar su inexistencia -por lo mismo carece de sentido catalogarlo de relativista-, ni mencionar que todos ellos son producto de un poder que los vuelve indiferenciables ${ }^{67}$, sino mostrar las condiciones de emergencia de nuestra experiencia, el proceso histórico que posibilita la constitución de nosotros mismos en tanto sujetos relacionados con saberes, normas y con nuestra propia subjetividad.

\footnotetext{
${ }^{67}$ Sobre este punto habremos de volver en el siguiente capítulo. Vale la pena señalar desde ahora, que Foucault vincula toda experiencia con procesos de normatividad entendidos como generación de normas que estructuran nuestro comportamiento. A partir de 1978, la noción de poder es definida en términos de gobierno, no como dominación ni como violencia, sino como la capacidad de estructurar los comportamientos de los otros. Parece bastante claro que no hay experiencia humana que pueda definirse fuera de ciertas normas que estructuran nuestro comportamiento, en ese sentido todas nuestras experiencias están vinculadas al poder, incluso nuestras formas de conocimiento. Esto no quiere decir ni que la verdad no exista, ni que la libertad sea una ilusión, ni que Foucault piense que todos los discursos normativos busquen "someter" al hombre, sino que el análisis de nuestra experiencia concreta implica un estudio del funcionamiento de las normas y de su relación con la constitución del sujeto. Este malentendido es uno de los lugares en los que comúnmente descansan ciertas críticas a Foucault. Por ejemplo: "La intención crítica de Foucault es radical y consiste en tratar de demostrar que esos modelos normativos de hombre, lejos de representar la liberación de los individuos, son el resultado de las disciplinas con las que se busca someter a los hombres a un orden establecido y, por tanto expropiarlos de su capacidad de ejercer el poder" (Serrano, 1994, 29).
} 
El afán crítico del trabajo de Foucault no debe valorarse por su capacidad para generar un canon evaluativo capaz de tomar distancia del proceso genético de formación de la experiencia. Tal y como es planteado por la tradición crítica iniciada por Kant, la autodeterminación del pensamiento supone el conocimiento de las condiciones de su propia constitución. El potencial crítico de un trabajo genealógico debe hallarse En su cualidadde ser un "ejercicio de sí del pensamiento" (HS2, 12) que nos permite conocer las condiciones de su formación en la dinámica de su propio proceso y no fuera de él. En ello radica su máxima virtud y también su máxima limitante. La comprensión de estas condiciones y la conciencia de las relaciones implícitas que el sujeto y el objeto deben suponer para experimentarse y ser experimentados como tales es, si no el único, al menos un factor irrenunciable para la autodeterminación del sujeto tanto en su individualidad, como en su práctica política. Todavía más, en consonancia con Kant, Hegel y Marx, Foucault intenta hacer explícitas las condiciones que imposibilitan la autodeterminación del sujeto. En su caso, este objetivo se lleva a cabo analizando la serie de prácticas concretas mediante las cuales, una y otra vez, nuestras conductas son dirigidas. Y de la misma manera en que para Kant, Hegel y Marx, la denuncia de factores que limitan la libertad del sujeto no los llevaba a la fatal consecuencia de negar la libertad, el proyecto del francés tampoco pretende afirmar que el poder prohíbe la acción autónoma de los individuos ${ }^{68}$. Por el contrario, Foucault desea señalar los elementos absolutamente concretos que limitan nuestra libertad,

\footnotetext{
${ }^{68}$ En este sentido Foucault se asemeja, quizá sin saberlo, al planteamiento epistemológico de Hegel. De la misma manera que el autor de la Fenomenología del espiritu, el francés no pretende negar la singularidad, ni subsumir la particularidad en un proceso totalizante, lo que sí desea enfatizar es que el análisis de la formación de nuestra experiencia no puede agotarse en un estudio de sujetos aislados o en la indagación de una subjetividad formal elevada a parámetro universal. Contrariamente a lo que algunos intérpretes han señalado ( $C f r$, Berman, 2008, 25), Foucault no supedita la existencia de la individualidad a un mecanismo anónimo y totalizante $(C f r$, Habermas, 2000,111), sino que, de forma paralela a Hegel, intenta mostrar que nuestra experiencia subjetiva es, a la vez, el resultado de la acción de un sujeto sobre sí mismo y el producto de las relaciones que enmarcan nuestras posibilidades de acción en el mundo.
} 
con el único afán de mostrar la posibilidad de resistirnos a aquellas formas de gobierno que restringen nuestra capacidad de auto-determinarnos. El francés entiende que la ampliación de nuestra libertad depende del conocimiento de los obstáculos que efectivamente la limitan, únicamente así es posible dibujar las formas de resistencia práctica que harían que nuestra libertad pase de un postulado de la razón a una realidad efectiva. Foucault tenía muy claro todo ello, por lo mismo en un texto de 1984 caracteriza todo su trayecto filosófico como "[...] un trabajo sobre nuestros límites, es decir, una labor paciente que da forma a la impaciencia de la libertad" (QI, 990).

\section{II.-El paso de la noción de poder a los conceptos de gobierno y}

\section{gubernamentabilidad}

En este capítulo intentaremos analizar minuciosamente la noción de poder en los textos de Michel Foucault, con el fin de valorar la importancia de este concepto dentro del contexto general de su trabajo. Al mismo tiempo, nos interesa estudiar las nociones de gobierno y gubernamentalidad, acuñadas por el autor a finales de la década de los 70's, ya que estamos convencidos que, gracias a ellas, es posible revalorar el sentido de su preocupación por el poder. El desarrollo de la filosofía de Foucault es un claro ejemplo de que el verdadero pensamiento avanza corrigiéndose a sí mismo una y otra vez hasta alcanzar sus objetivos. En particular, la evolución del concepto de poder nos hace patentes las dificultades que 
nuestro autor debió superar para darle coherencia teórica y fortaleza argumentativa a su proyecto. Por lo mismo, creemos necesario revisar cuidadosamente el trayecto que lo llevó a su peculiar concepción de poder, para tener una mejor comprensión del papel que cumple y los problemas teórico-conceptuales que pretende solventar. Una visión amplia de las vicisitudes de su camino intelectual y conceptual, puede permitirnos entender su aparente “obsesión” por el tema del poder y el sentido general de sus indagaciones filosóficas. Para ello, debemos poner especial atención en un periodo poco explorado y, generalmente, mal interpretado por quienes tienen una opinión más o menos formada acerca del trabajo foucaultiano, nos referimos a la segunda mitad de la década de los 70's. El análisis de las transformaciones conceptuales que el francés realiza en esa época, resulta de capital importancia si queremos hacer un balance adecuado de su pensamiento.

Ya en las primeras clases del curso de 1976, el autor de Vigilar y castigar intenta desplazarse de ciertas posturas que, según su visión, terminan reduciendo la complejidad de la noción de poder. Para ello, distingue didácticamente dos modelos de conceptualización, que según Foucault, predominaban en su época: por un lado, el poder era concebido desde una perspectiva jurídico-económica, y por el otro, era analizado con una terminología que aludía a la represión y la guerra. En 1976, Foucault acepta haber situado sus trabajos precedentes en este último bloque, si bien en esos años negaba que el poder pudiera explicarse en términos de represión ${ }^{69}$, asumía que su dinámica era el reflejo permanente de relaciones bélicas ${ }^{70}$. Para diferenciarla de las otras, Foucault va a darle a esta vertiente el nombre de "hipótesis Nietzche". Ahora bien, en el mismo seminario, el francés pone en

\footnotetext{
${ }^{69}$ La crítica de esta postura la encontraremos ya en el primer volumen de Historia de la sexualidad 1 (Cfr, HS1, 23ss).

${ }^{70}$ (Cfr, MP, 90-91).
} 
cuestión esta postura y toma distancia de la misma. Al parecer, comprende que esta forma de análisis no refleja suficientemente la complejidad de las relaciones de $\operatorname{poder}^{71}$. De hecho, gran parte del seminario de ese año está destinada a realizar la genealogía de esta hipótesis; es decir, a indagar críticamente su desarrollo histórico. Dos años después, en el seminario titulado Seguridad, territorio, población, Foucault comenzará a preocuparse por una categoría que marcará los derroteros de su trabajo posterior: la noción de gobierno. Ya sea en la indagación de la gubernamentalidad estatal, ya sea en el análisis del gobierno de sí y de los otros, Foucault volverá una y otra vez sobre este tema. A nuestro entender, ésta noción le otorga un instrumento conceptual de largo alcance ante la insuficiencia que él mismo había observado en la "hipótesis Nietzche".

Con la intención de llevar a cabo nuestro objetivo, analizaremos las razones que lo hacen desplazarse de los modelos jurídico-económico y de “guerra y represión”. Posteriormente, estudiaremos cómo surgen las nociones de gobierno y gubernamentalidad y a qué intentan dar respuesta. Antes de iniciar este análisis debemos aclarar que estos modelos sólo son esbozos esquemáticos que Foucault usa para realizar una exposición didáctica. En ella, el francés pretende aclarar la especificidad de su forma de abordar el problema del poder y sólo el problema del poder. Para efectos de esta investigación, no discutiremos la pertinencia de los esquemas que Foucault hace del marxismo y del modelo jurídicoeconómico; no es nuestro objetivo indagar si son adecuados o no, si terminan reduciendo las complejidades de estas posturas o no, o si, en última instancia, su comprensión del marxismo, del derecho o del psicoanálisis es parcializada. En todo caso, vale la pena señalar que en el contexto de este seminario, Foucault no pretende hacer ni el esbozo de ${ }^{71}(C f r, \mathrm{DS}, 30)$. 
una teoría, ni una crítica exhaustiva del derecho o del marxismo, únicamente intenta mostrar la especificidad de su modo de abordaje. Resulta evidente que basados en estos esquemas no podríamos señalar, ni la complejidad de la relación de Foucault con el marxismo, ni el esbozo de una teoría del derecho, ni la ambivalente relación del francés con el psicoanálisis.

Por último, debemos aclarar que el francés no considera que estos modelos sean falsos o inútiles, lo que denuncia es la insuficiencia de los mismos para dar cuenta del desarrollo efectivo de conflictos sociales particulares. Sin ser consciente de ello, Foucault procede de manera dialéctica en la depuración de su noción de poder. En efecto, el desplazamiento que lo lleva de un modelo de análisis a otro, no debe entenderse como la negación absoluta de cierta concepción para erigir otra venida de la mente del francés, sino como el abandono de una perspectiva que, sin ser del todo falsa, se presenta como insuficiente y, por lo mismo, debe ser superada para poder dar cuenta de la realidad, ya que, al fin y al cabo, es ella la que condiciona la validez de las construcciones conceptuales. A pesar de que, por razones didácticas, expongamos el desarrollo de la concepción de poder foucaultiana en cinco grandes bloques, es necesario tomar en cuenta el apunte anterior para entender correctamente el proceder del francés. La noción de gobierno que, finalmente, corona la búsqueda de Foucault destinada a dotarse de una categoría de análisis suficientemente amplia para dar cuenta de la pluralidad de los conflictos sociales, no es absolutamente distinta de los modelos que rechaza, más bien los contiene al momento de superarlos. Así pues, la categoría de poder fraguada por Foucault mantiene las aportaciones de las perspectivas anteriores, pero intenta ampliar su horizonte de inteligibilidad. En buena medida, la crítica que el autor de Las palabras y las cosas le dirige a las concepciones de 
poder precedentes, consiste menos en denunciar su falsedad que en hacer ver la unilateralidad de su postura y la insuficiencia de la misma al intentar dar cuenta de las múltiples formas que toman las relaciones de asimetría en el desarrollo histórico.

\section{1.- Desplazamiento del modelo jurídico-económico}

\subsection{1.- El modelo economicista}

Comencemos analizando el desplazamiento de Michel Foucault con el modelo económicojurídico del poder ${ }^{72}$. La relación del filósofo francés con el marxismo es compleja, llena de matices y ambigüedades. En muy pocos años, Foucault pasa de ser un adherente del partido comunista a renegar del marxismo de manera furibunda ${ }^{73}$. Todavía en los primeros años de la década de los 70’s, era común escuchar al francés hablar con términos marxistas en entrevistas y conferencias; sin embargo, ya en 1976, el autor de Las palabras y las cosas explica que la especificidad y originalidad de su trabajo depende, en gran medida, de haber tomado distancia de cierta concepción marxista -que no de Marx $^{74}$ - del poder.

Foucault cree que el principal problema del marxismo de su época es que reduce la dinámica del poder a un funcionalismo economicista, esto "[...] en la medida en que el papel del poder consistiría, en esencia, en mantener relaciones de producción y, a la vez,

\footnotetext{
${ }^{72}$ Según el francés, tanto la perspectiva que conceptualiza al poder en términos jurídicos, como la que lo hace en términos económicos, comparten una visión economicista del poder "[...] hay cierto punto en común entre la concepción jurídica [...] y la concepción marxista o, en todo caso, cierta concepción corriente que pasa por ser la del marxismo. Ese punto en común sería lo que yo llamaría economicismo en la teoría del poder" (DS, 26).

${ }_{74}^{73}$ (Cfr, Eribon, 2004, 193ss).

${ }^{74}$ Debemos precisar que la relación de Foucault con Marx es más compleja de lo que aquí se presenta. Foucault no se desprende en realidad de Marx, sino de cierto marxismo dogmático muy común en los 50's y los 60's. Da cuenta de ello la siguiente aclaración hecha por el francés: "Aun cuando uno admita que Marx está hoy en vías de desaparecer, no hay duda de que volverá a aparecer. Es lo que yo deseo [...] la restitución de un Marx auténtico [...] la liberación de Marx de los dogmas de partido que durante tanto tiempo lo han aprisionado", citado en: Lemke, Thomas, "Marx sin comillas: Foucault, la gubernamentabilidad y la crítica contra el neoliberalismo", en : (Lemke, 2006, 5).
} 
prorrogar una dominación de clase que el desarrollo y las modalidades características de la apropiación de las fuerzas productivas hicieron posible. En este caso, el poder político encontraría su razón de ser histórica en la economía" (DS, 27). Ahora bien, para nuestro autor, esta reducción no permite llevar a cabo una comprensión profunda de la complejidad existente en las relaciones de poder. Entiéndase bien, Foucault no niega la existencia de una dominación provocada por la apropiación de las fuerzas productivas, ni niega la existencia de la explotación económica, lo que sí afirma es que identificar inmediatamente el poder con las relaciones de explotación no es suficiente para dar cuenta de las múltiples formas que toman los fenómenos de asimetría en las sociedades actuales. El francés cree que el análisis del poder exige una metodología de análisis distinta, la cual debe enfocarse en recorrer históricamente las condiciones de posibilidad específicas de ciertas constelaciones de prácticas particulares, para comprender su funcionamiento y la lógica de su racionalización. No es posible, por tanto, remitir de forma inmediata todas las acciones humanas en que se puede observar el ejercicio del poder a la disposición social que genera la estructura del capital.

De esto no se sigue que Foucault niegue la perspectiva crítica marxista que denuncia la dominación de clase surgida por la lógica del capital, sino algo mucho más específico. El autor de Vigilar y castigar desea señalar las limitaciones que esta posición puede tener si pretende reducir la explicación del funcionamiento de las prácticas efectivas de poder a un esquema tan general que, finalmente, desdibuja las diferencias existentes en su ejercicio real y en las condiciones que dan cuenta de su aparición. El francés critica, con razón, la metodología de análisis de ciertos estudios marxistas de la época, pues si bien parten de un 
hecho históricamente sostenible -el ascenso de la burguesía desde los siglos XVI y XVII ${ }^{75}$ , derivan de él, de forma inmediata y sin matices, la explicación de todas las formas de dominación. Por su parte, Foucault intenta defender una forma de abordaje distinta, en lugar de partir de la diferencia de clases para explicar las formas de poder, estudia las estrategias, técnicas y dispositivos que generan fenómenos específicos de represión, dominación o explotación, para comprender la racionalidad interna que permite el funcionamiento de estas prácticas. Una vez analizada su lógica concreta y sus particulares condiciones de posibilidad, resulta más fácil entender por qué ciertas técnicas fueron retomadas o absorbidas por las dinámicas de la producción y la explotación capitalista. En vez de identificar de forma inmediata poder con explotación capitalista, Foucault decide estudiar las peculiaridades de las relaciones de asimetría para comprender en qué medida y por qué razones pudieron ser útiles dentro de las prácticas que el capitalismo reproduce:

Creo que lo que hay que hacer es lo inverso, es decir, ver históricamente cómo, a partir de abajo, los mecanismos de control pudieron actuar [...] cómo [...] esos fenómenos de represión o exclusión tuvieron sus instrumentos, su lógica, y respondieron a cierta cantidad de necesidades; mostrar cuáles fueron sus agentes, y no buscarlos en absoluto por el lado de la burguesía en general, sino por el lado de los agentes reales [...] y cómo esos mecanismos de poder en un momento dado, en una coyuntura precisa y mediante una serie de transformaciones, comenzaron a volverse económicamente redituables y políticamente útiles (DS, 40).

Así, antes de intentar explicar cómo puede prolongarse el poder que posee una clase sobre los estratos inferiores, el francés desea entender las condiciones que hacen posible la existencia de mecanismos que, al mismo tiempo que operan en la realidad, construyen su propia lógica y sus propias formas de sometimiento. Foucault quiere dejar claro que las

\footnotetext{
${ }^{75}$ Por ejemplo, Foucault señala en el seminario de 1976: “[...] a partir del siglo XVI y en el XVII, la burguesía se convirtió en la clase dominante" (DS, 39).
} 
dinámicas de las relaciones de poder deben explicarse a partir de los mecanismos concretos que las hacen funcionar, por lo mismo, la explicación de su origen y de sus posibilidades no puede agotarse con la alusión al sistema de explotación económico fundado en la apropiación de la fuerza de trabajo. Ciertamente, una clase dominante tiene mayores posibilidades para poner en marcha algunos dispositivos de poder, pero afirmar que la burguesía es el principal portavoz de la dominación en las sociedades actuales no es suficiente para entender cómo funcionan las relaciones de poder, cuáles son sus mecanismos concretos, en qué consiste su especificidad y qué tipo de subjetividad surge de su aplicación. Todavía más, aceptar a pie juntillas esta postura puede llevarnos a creer que el poder es una sustancia, una "cosa" susceptible de ser poseída por una clase capaz de imponer ciertas limitaciones a otra.

Ahora bien, Foucault cree que si se asume como criterio de validación teórica la propia historia y sólo la propia historia, resulta inevitable admitir que existen relaciones de poder que no sólo circulan de manera vertical, sino que son reproducidas dentro de las dinámicas de la misma clase social. Decir, entonces, que el poder puede ser concebido como la propiedad de una clase que somete a otra es, al menos, insuficiente. Lo que está de fondo, más allá de las discusiones sobre lo adecuado o no de la perspectiva marxista, es la forma de caracterizar las relaciones de poder, Foucault considera que éstas no pueden definirse en términos de posesión. El poder no es una sustancia. De ahí que Foucault enfatice tanto la necesidad de estudiar no ya su composición sustancial última, sino los procesos de constitución histórica que hacen emerger relaciones de poder. Esos procesos se manifiestan en los mecanismos concretos, plurales y multidireccionales que continuamente redefinen las diferentes formas de poner una voluntad al servicio de otra. Sin duda, el poder puede 
ser utilizado, esgrimido, propagado y aplicado por un sector sobre otro, pero resulta absolutamente inadecuado a nivel conceptual remitirlo inmediatamente a una clase social. .

Con esto no se niega, aunque tampoco se confirma, el diagnóstico de la sociedad hecho por Marx. Simplemente se nos explica que para entender el fenómeno del poder, resulta insuficiente aquella explicación que hace derivar todas sus manifestaciones de las relaciones de producción. Según Foucault, el marxismo caía en una especie de contradicción porque, ante la evidencia empírica de múltiples formas de sujeción, éste adaptaba esa constelación compleja a la forma de la explotación. En buena medida, podemos entender el desplazamiento de Foucault con respecto al marxismo como una forma de desprendimiento de la influencia que Althusser había ejercido en el panorama intelectual francés de la época. Veamos.

El autor de Para leer el Capital intentaba dar respuesta al problema del poder a partir de la noción de "aparatos ideológicos de Estado", pero, como veremos, no dejaba de supeditar la multiplicidad de estos aparatos a la ideología dominante que, en todo caso, en la modernidad, es la de la explotación capitalista. Ya en "Ideología y aparatos ideológicos de Estado", el marxista francés intentaba responder una pregunta fundamental: ¿Cómo se asegura la reproducción de las relaciones de dominación que, desde su perspectiva, se identifican con las relaciones de producción? Con estas últimas, el autor hacía referencia a las relaciones de producción capitalistas que son para él, relaciones de explotadorexplotado $^{76}$. Por lo mismo, las preguntas que dicho texto pretende resolver son las siguientes: ¿Cómo es posible que los sujetos reproduzcan las relaciones de explotación?,

\footnotetext{
76 “Ahora bien, las relaciones de producción de una formación social capitalista, es decir las relaciones entre explotador y explotado [...]” (Althusser, 2005, 126-127).
} 
¿A través de qué medios la explotación se normaliza como relación social válida entre los hombres? La respuesta althusseriana a esas preguntas era la siguiente: estas relaciones se aseguran por la superestructura jurídico-política ${ }^{77}$ e ideológica. Pero para ir más allá del vocabulario de estructura y superestructura propuesto por Marx, Althusser afirmaba que la reproducción ${ }^{78}$ de las relaciones de producción se asegura "por el ejercicio del poder del estado, en el aparato (represivo) del estado, por una parte, y en los aparatos ideológicos del estado, por otra" (Althusser, 2005, 120).

La propuesta althusseriana tiene dos grandes virtudes: a) el concepto de aparato, pues con éste se pretende enfatizar el carácter material de la ideología, la cual se presenta en instituciones concretas que inducen una serie de prácticas específicas, y b) al afirmar que no sólo es el aparato represivo el que salvaguarda el orden político, se aleja de aquella idea según la cual las relaciones de poder político se perpetúan tan sólo por la fuerza o la represión. Con ello, abre la posibilidad de pensar el poder más allá del monopolio de la violencia. Sin embargo, vemos con claridad que sigue partiendo de una concepción del poder centralizada y unidimensional, pues a pesar de que los aparatos ideológicos poseen cierta independencia del Estado, como él mismo lo afirma, éstos se supeditan en todo

\footnotetext{
${ }^{77}$ Recordemos que Marx, en el prólogo de la Contribución a la crítica de la economía política, señala que el resultado general de sus estudios en dicha materia lo había llevado a la siguiente conclusión, misma que servirá de base para todos sus trabajos posteriores: "[...] en la producción social de su vida los hombres contraen determinadas relaciones necesarias e independientes de su voluntad, relaciones de producción que corresponden a una determinada fase de desarrollo de sus fuerzas productivas materiales. El conjunto de estas relaciones de producción forma la estructura económica de la sociedad, la base real sobre las que se levanta la superestructura jurídica y política y a la que corresponden determinadas formas de conciencia social. El modo de producción de la vida material condiciona el proceso de la vida social política y espiritual en general" (Marx, 2008, 4-5):

${ }^{78}$ Althusser afirma que la metáfora establecida por Marx de estructura y superestructura resulta insuficiente para entender a cabalidad el problema de la superestructura, por ello habilita otro lenguaje capaz de presentar mejor esa realidad y acude a la idea de "reproducción". Afirma: "Consideramos que a partir de la reproducción es posible y necesario pensar lo que esencialmente caracteriza la existencia y la naturaleza de la superestructura" (Althusser, 2005, 110).
} 
momento a la ideología dominante que, como se ha dicho, es la ideología capitalista protegida por el aparato estatal ${ }^{79}$.

Esta posición le parece unilateral al autor de El orden del discurso, mas no falsa, pues no capta la especificidad de cada mecanismo de poder ni las finalidades particulares que persigue:

Conozco las objeciones que se pueden hacer. Podemos decir que todos los tipos de sujeción son fenómenos derivados, meras consecuencias de otros procesos económicos y sociales: fuerzas de producción, luchas de clases y estructura ideológica que determinan las formas de subjetividad [...] Es cierto que los mecanismos de sujeción no pueden ser estudiados por fuera de su relación con los mecanismos de dominación y explotación. Pero ellos no constituyen lo "terminal" de muchos de los mecanismos fundamentales. Ellos conforman relaciones complejas y circulares con otras formas" (SP, 246).

El hecho de que Foucault se desplace de esta forma de análisis, no significa que su filosofía considere los procesos de dominación y explotación económica como un tema de poca monta; todo lo contrario, el francés desea enfatizar que un análisis del poder requiere captar la complejidad específica de cada mecanismo y, una vez comprendida su lógica interna, revalorar su funcionamiento dentro de procesos de mayor amplitud. Sin embargo, esta pretensión teórica genera una precaución metodológica que se volverá problemática en los trabajos teóricos de Foucault. El peligro inmediato que la visión marxista le permite alertar, es aquel que se presenta cuando un fenómeno múltiple es reducido a uno sólo de sus factores. Para evitar caer en este peligro, nuestro autor centra sus análisis en el cómo de las diferentes relaciones de poder antes que en el $q u e^{80}$, sin embargo, como veremos más adelante, este golpe de timón no es del todo suficiente, pues lo lleva a adoptar un concepto

\footnotetext{
${ }^{79}$ (Cfr, Althusser, 2005, 120-121).

${ }^{80}$ Como veremos más adelante, es hasta 1978 que Foucault trata de dar una definición del poder apelando a la noción de gobierno.
} 
de poder enmarcado en el vocabulario de la lucha y la guerra, el cual, a la postre, se presentará como algo ambiguo e insuficiente.

En síntesis, Foucault considera que la visión marxista de las relaciones de poder es "economicista" y, por lo mismo, insuficiente, en dos niveles. En primer lugar, porque reduce la diversidad de los mecanismos de poder a las relaciones de dominación económicas, y en segundo lugar, porque supone que el poder es poseído e implantado por una clase sobre otra. Debemos ser enfáticos en lo siguiente, esto no quiere decir que, en los hechos, no haya estructuras económicas que favorezcan las desigualdades sociales y la explotación de un grupo social sobre otro, lo único que el francés quiere explicar es que el poder ni puede reducirse a este tipo de relación, ni debe ser definido esencialmente como la posesión de una clase social que oprime a la otra, pues esto limitaría y predefiniría a priori los resultados de toda investigación particular:

No he querido identificar poder y opresión en absoluto ¿Por qué? En primer lugar porque pienso que no hay un poder, sino que, dentro de una sociedad, existen relaciones de poder extraordinariamente numerosas y múltiples, colocadas en diferentes niveles, apoyándose unas sobre otras y cuestionándose mutuamente. Relaciones de poder muy diferentes se actualizan en el interior de una institución, por ejemplo, en las relaciones de clase o en las relaciones sexuales tenemos relaciones de poder y sería simplista afirmar que éstas son la proyección del poder de clase. [...] Las relaciones de poder son sutiles, múltiples y se dan en distintos niveles; no podemos hablar de un poder sin describir las relaciones de poder, tarea larga y difícil que acarrearía un largo proceso. Podríamos estudiarlas desde el punto de vista de la psiquiatría, la sociedad o la familia, pero estas relaciones son tan múltiples que no pueden ser definidas como opresión resumiendo todo en una frase: «el poder oprime» (VFJ, 179).

Por último, Foucault cree que si de inicio aceptamos que el poder es la posesión exclusiva de una clase social, surge la tentación de concluir que la eliminación de las relaciones de 
asimetría depende de la "transferencia" de las mismas a otra clase que, finalmente, las haría desaparecer:

Para los auténticos revolucionarios apoderarse del poder significa arrancar un tesoro de las manos de una clase para entregarlo a otro que, en este caso, es el proletariado. Creo que así se concibe la revolución y la toma de poder. Pero observemos entonces a la Unión Soviética, un régimen en el que las relaciones de poder en el seno de la familia, la sexualidad, las fábricas, las escuelas, son las mismas que se conocen en Occidente. El problema es saber si podemos, dentro del actual régimen, llevar a niveles microscópicos las relaciones de poder de tal manera que, cuando se produzca una revolución político-económica, no encontremos después las mismas relaciones de poder que hoy existen (VFJ, 179-180).

Este punto es de gran importancia. Si el poder se concibe como una propiedad capaz de ser poseída, resulta fácil confundir a sus poseedores con el ejercicio del mismo. De ahí que sea posible suponer que una vez eliminada la clase social que detenta los privilegios económicos, también desaparecerán las relaciones asimétricas. Foucault cree que ciertos discursos marxistas en vez de enriquecer la crítica de Marx al sistema de acumulación capitalista terminan encorsetándola, pues lejos de sumergirse en la inmensidad de relaciones de poder que hacen posible y aceptable un sistema político específico -así sea uno fundado en las relaciones de explotación capitalista-, circunscriben el análisis a una sola de sus dimensiones. Incluso si se acepta que existe una relación jerárquica (estructurasuperestructura $^{81}$ entre el sistema de producción y los distintos mecanismos que reproducen las relaciones de poder, resulta limitada la posición que pretende explicar tanto las causas, como el funcionamiento interno de todas las redes de poder, por la dominación

\footnotetext{
${ }^{81}$ Foucault enfatiza que su crítica no se dirige a Marx, sino a las versiones de Marx que pululaban en la época. Si uno lee con cuidado las obras marxistas, se dará cuenta de que esta diferenciación no es tan rígida como sus opositores han querido mostrar.
} 
de una clase sobre otra. Para mostrar los peligros de esta perspectiva teórica, Foucault utiliza el ejemplo de la Unión Soviética, pues si es verdad que -al menos nominalmente- el régimen político económico fue transformado, esta transformación no trajo consigo la eliminación parcial o total de relaciones de poder y dominación. Todo lo contario, en el seno de un sistema económico distinto se generaron otras relaciones de poder.

Como se ve, la crítica de Foucault a la categoría de poder que el análisis de corte marxista proporciona, no consiste en mostrar la falsedad de su postura o en negar sus conclusiones sobre el diagnóstico de la realidad, sino en dar cuenta de la unilateralidad de su perspectiva. En este caso, el concepto marxista de poder es insuficiente porque trata de subsumir la pluralidad de mecanismos de sujeción a una relación de clase. Esta apresurada identificación, a su vez, se funda en una visión sustancialista del poder, la cual termina otorgándonos una concepción cerrada y limitada del mismo. Claramente, la dinámica de ciertas sociedades las hace más proclives a instaurar relaciones de sujeción fundadas en la explotación y en la apropiación de la fuerza de trabajo, pero incluso un análisis que asuma esta realidad, debe ampliar el entramado conceptual que le permite comprender las diversas formas en que las relaciones de asimetría se reproducen y transforman; de otra manera, se verá obligada a circunscribir sus diagnósticos a un esquema incapaz de asimilar las incesantes transformaciones que sufren las relaciones de sujeción en nuestras sociedades.

\subsection{2.- El modelo jurídico}

Ahora bien, Foucault cree que además de la postura marxista dominante en su época existe otro tipo de análisis del poder que, en lo esencial, posee sus mismas limitaciones. A ese tipo de análisis Foucault lo llama modelo jurídico. De manera semejante a la perspectiva 
marxista, esta forma de abordar el tema del poder lo reduce a una relación de corte económico, lo sustancializa y asume que es una entidad que puede transferirse. Por razones que a continuación analizaremos, a ésta postura nuestro autor le da el nombre de modelo jurídico. En el mismo seminario en que analiza la perspectiva marxista, Foucault realiza una valoración de ese modelo, revisa sus problemas, sus obstáculos y sus deficiencias. Veamos cuáles son sus conclusiones.

Empecemos con una aclaración. Para no perdernos en un falso debate, vale la pena señalar que en esta reflexión, el francés no trata de indagar los aportes de las teorías del derecho contemporáneas, ni de explicar normativamente la función del sistema jurídico. Con el fin de evitar todo posible equívoco, debemos decir desde ahora que Foucault entiende por modelo jurídico la teoría de la soberanía, no porque reduzca el derecho a una relación de mando-obediencia, sino para esquematizar cierta concepción del poder que, en la teoría política del siglo XVIII, ponía en relación las nociones de poder, contrato y soberano. El análisis de Foucault se encuentra en un contexto bien específico: el intento de clarificar y distinguir su forma de abordaje en lo tocante a la noción de poder. Por lo mismo, cuando se refiere al "modelo jurídico" parte de una generalización bastante didáctica, cuya función es englobar la multiplicidad de aquellas teorías político-jurídicas que, a pesar de sus diversos matices, coinciden en la forma de plantearse el problema del poder político. Por último, en el curso de 1976, Foucault no tiene el interés de criticar la pertinencia del modelo jurídico en sí mismo, sino sólo cuando se vuelve un instrumento de análisis del poder.

En esencia, lo que está en juego en las concepciones del poder que se identifican con el modelo jurídico, es el problema de la soberanía y su legitimidad. Según Foucault, estas 
concepciones intentan solventar la siguiente dificultad: ¿A partir de qué mecanismos se genera una transacción en la que se obtiene como resultado un soberano legítimamente constituido $?^{82}$ Foucault muestra que esta problemática ocupa un lugar esencial en las teorías políticas de Occidente desde la reactivación del derecho romano ${ }^{83}$ en siglo $\mathrm{XI}^{84}$ y su florecimiento en el siglo XIII ${ }^{85}$. A su entender, la reactivación del derecho romano redirigió el horizonte de las disputas teóricas hacia la figura del rey. Ya sea para mostrar la legitimidad de su poder, ya sea para demostrar la necesidad de limitarlo, él era el centro de la reflexión teórica:

[...] ya fuera para mostrar en qué basamento jurídico se investía ese poder, de que forma el monarca era efectivamente el cuerpo viviente de la soberanía, cómo su poder, aun absoluto, se adecuaba exactamente a un derecho fundamental; ya fuera, al contrario, para mostrar cómo había que limitar ese poder del soberano, a qué reglas de derecho debía someterse, según y dentro de qué limites tenía que ejercer su poder para que éste conservase su legitimidad. Desde la Edad Media, la teoría del derecho tiene como papel esencial fijar la

${ }^{82}$ En el primer volumen de Historia de la sexualidad Foucault esquematiza las limitaciones de las concepciones de poder dominantes en su época. Una de las características que, según el francés, obstaculizan la posibilidad de una analítica del poder, consiste en considerarlo bajo lo que él llama "la instancia de la regla". Para los estudios del poder que se fundan en esta instancia, el poder sería lo que dicta la ley, actuaría realizando una división binaria entre lo permitido y lo prohibido, lo lícito y lo ilícito, lo legítimo e ilegitimo. Esto, a su vez, querría decir que el poder actúa esencialmente generando algo así como un "estado de derecho"; es decir, estableciendo una distinción entre lo permitido y lo prohibido. Esta formulación bien puede hallarse en el vocabulario político corriente. En él, hablar de poder quiere decir fundamentalmente dos cosas: por un lado, la fuerza de un soberano, un grupo, una nación, ora para reprimir, prohibir o coartar la libertad de un súbdito u otra nación, y, por el otro, su capacidad de pronunciar el orden de lo permitido y lo prohibido. Sin embargo en el primer volumen de su Historia de la sexualidad, el francés muestra que ese modelo no es exclusivo de ciertas teorías políticas, sino que, en lo esencial, cuando el psicoanálisis intenta analizar los conflictos sociales parte de un esquema semejante. Las visiones psicoanalíticas que afirman que la ley constituye el deseo parten de la siguiente idea: la ley genera una estructura subjetiva que determina la división psíquica entre lo prohibido y lo permitido ( $C f r$, HS1, 112ss).

${ }^{83}$ (Cfr., DS, 42ss).

${ }^{84}$ Según Grossi los juristas del siglo XI carecían de un soporte de "validez" que le diera autoridad a sus esfuerzos teóricos, esa problemática vino a solventarse al acudir al derecho romano. Pero cuando hablamos de derecho romano, en realidad nos referimos al "derecho romano" tal cual lo codificó Justiniano en el siglo VI (Cfr., Grossi, 2007, 46-50).

${ }^{85}$ La reactivación del famoso Digesto de Justiniano, hace aparecer una concepción jurídica inexplorada en el Medievo: la de una autoridad jurídica centralizada. De tal forma que en el siglo XIII, tanto el rey de Francia, como el propio papa comenzarán a esgrimir la idea de que la legitimidad de la ley depende de la promulgación de un príncipe (Sabine, 2006, 225-231). En ese contexto, el derecho comienza a desplazarse de un plano descentrado, bastante habitual en la Alta Edad Media, a un escenario en el que resalta el problema del soberano, quien determina la validez de la legalidad. 
legitimidad del poder: el problema fundamental, central, alrededor del cual se organiza toda esa teoría, es el problema de la soberanía (DS, 35$)^{86}$.

Esta forma de plantearse el problema político ha sufrido muchísimas variantes y ha cumplido distintos papeles históricos, Foucault resume brevemente cuatro. En primer lugar, dice, se refirió a un mecanismo efectivamente existente: la monarquía feudal. Posteriormente sirvió como instrumento y justificación de las grandes monarquías administrativas. En los siglos XVI y XVII fungió como arma teórica tanto a favor de los partidarios de la monarquía como de los partidarios del parlamento. Finalmente, en el siglo XVIII, en contra de las monarquías administrativas autoritarias, emergió como el fundamento teórico de las posiciones que buscaban instaurar democracias parlamentarias ${ }^{87}$. Con todas las enormes diferencias que se pueden observar en estos periodos, lo que a Foucault le importa destacar es que, en todos los casos, se da por sentado que un agente detenta el poder. No importa que esa consideración tenga la finalidad de justificar su legitimidad o manifestar su ilegitimidad y la necesidad de transformar el sistema político.

\footnotetext{
${ }^{86}$ Históricamente, el largo periodo medieval estuvo caracterizado por eso que Grossi llama "carácter incompleto del poder" (Cfr., Grossi, 2007, 50); es decir, la incapacidad de un poder de totalizarse para intervenir en la mayor parte de las actividades sociales y controlarlas por cualquier medio a su disposición. Como es sabido, la aparición del feudalismo generó un fenómeno que algunos teóricos han denominado "policentrismo" del poder, sin embargo ya en el siglo XIII es posible observar una paulatina limitación de los poderes feudales. Esta limitación es el resultado de la progresiva centralización de dos elementos fundamentales para lo que, a la postre, será el Estado moderno: el ejército y las instituciones judiciales. "Si el rey limitó y redujo poco a poco los juegos complejos de los poderes feudales, lo hizo en su carácter de piedra angular de un Estado de justicia, redoblado por un sistema armado" (DS, 23). Por lo tanto, en su funcionamiento efectivo la práctica jurídica permite multiplicar el poder real, pues se arroga funciones que tradicionalmente se habían procesado entre particulares. Desde la última etapa del Medievo la teoría jurídica tiende a centrar su preocupación en la figura del soberano. Foucault no soslaya el problema del constitucionalismo medieval que tiene por función limitar el poder real, pero afirma dos cosas: por una parte aparece como limitación interna al propio poder real, y por otra, menciona que, de hecho, funciona bajo el entendido tardomedieval de que el "poder" se identifica con el soberano. ( $C f r$, VFJ).

${ }^{87}$ Foucault destaca que en el siglo XVIII la teoría de la soberanía tenía la función de: “[...] construir, contra las monarquías administrativas, autoritarias o absolutas, un modelo alternativo, el de las democracias parlamentarias"(DS, 43).
} 
Ahora bien, nuestro autor cree que las discusiones de tipo contractual replantean la problemática política en los mismos términos que la teoría jurídica del soberano lo hacía desde el siglo XI, aunque su contexto, sus repercusiones y sus objetivos sean distintos. A pesar de las innumerables diferencias históricas y teóricas, resulta factible afirmar que el problema a resolver a partir de ese modelo es, precisamente, el de la legitimidad jurídica del poder político. No creemos equivocarnos si afirmamos que éste es el tema central de una determinada concepción de la filosofía política que va desde el Leviathan de Hobbes ${ }^{88}$ hasta el Contrato social de Rousseau ${ }^{89}$, pasando por el Segundo ensayo sobre el gobierno civil de Locke ${ }^{90}$. De lo que se trata, en todos estos casos, es de mostrar racionalmente en dónde se encontraría la legitimidad de la soberanía política. Para ello se recurre a un modelo contractual que tendría como ventaja generar una hipótesis fundada en la aceptación voluntaria. Independientemente de que el poder soberano se deposite en un monarca, un parlamento o en la voluntad general, la pretensión consiste es racionalizar el poder político desde el momento que se le hace pasar por una voluntad libre manifestada a través de una operación jurídica en el orden de un contrato de intercambio.

Frecuentemente se les reprocha a los críticos del contractualismo no comprender que su trabajo parte de una estrategia discursiva peculiar, la cual no intenta remitirnos a la génesis

\footnotetext{
88 "La instauración del poder soberano como persona (jurídica) capaz de gobernar se establece en la situación hipotética en que cada hombre dijera a todos: 'autorizo y transfiero a este hombre o asamblea de hombres mi derecho de gobernarme a mí mismo, con la condición de que vosotros transfieran e él vuestro derecho y autorizareis todos sus actos de la misma manera [...]' El titular de esta persona [a la que se le cedió el derecho de gobernarse a sí mismo] se denomina SOBERANO, y se dice que tiene poder soberano; cada uno de los que le rodean es su SÚBDITO" (Hobbes, 2006, 140).

${ }^{89}$ Dice Rousseau al iniciar el contrato social: "Algunos se creen los amos de los demás aun siendo más esclavos que ellos. ¿De qué manera se ha producido este cambio?, Lo ignoro. ¿Qué puede hacerlo legítimo?. Creo poder resolver esta cuestión" (Rousseau, 2002, 4). De hecho el Contrato Social también es conocido como Principios del derecho politico.

${ }^{90}$ En el Ensayo sobre el gobierno civil, Locke deja claro que son: "Las personas que viven unidas formando un mismo cuerpo y que disponen de una ley común sancionada y de un organismo judicial al que recurrir, con autoridad para decidir las disputas entre ellos y castigar a los culpables" (Locke, 2005, 85).
} 
histórica de los acontecimientos, sino a un modelo de explicación racional. Foucault conoce de sobra el sentido de este desplazamiento teórico. De hecho, en la clase del 4 de febrero de $1976^{91}$ muestra que el planteamiento de Hobbes tiene la finalidad de enfrentar una práctica discursiva recurrente en la época del filósofo inglés, aquella que intentaba justificar el poder del soberano a partir de narraciones de hechos históricos ${ }^{92}$. El francés comprende bien que, al menos en el Leviatán, hay una tesis hipotético-deductiva y no una narración histórico-genética y sobre todo, muestra que la intención de Hobbes es evidenciar la irracionalidad de las explicaciones histórico-narrativas. El desplazamiento del modelo jurídico no es el resultado de su incomprensión de la estrategia contractual, sino, como veremos, el paso obligado que debe dar una analítica del poder para cumplir sus objetivos. Sin duda, el paradigma contractual nos ofrece herramientas de trabajo valiosas para la construcción de modelos normativos, pero debido a su estructura argumentativa nos ofrece una visión del poder bastante endeble, ya que termina conceptualizándolo:

[como un] poder concreto que todo individuo posee y que, al parecer, cede, total o parcialmente, para construir un poder, una soberanía política. En esta serie, en este conjunto teórico al que me refiero, la constitución del poder político se hace, entonces, según el modelo de una operación jurídica que sería del orden del intercambio contractual $(\mathrm{DS}, 26)^{93}$.

\footnotetext{
${ }^{91}(C f r, \mathrm{DS}, 85 \mathrm{ss})$.

${ }_{92}^{92}(C f r, \mathrm{DS}, 87 \mathrm{ss})$.

${ }^{93}$ Hobbes afirma claramente que para los hombres: "El único camino para erigir [un] poder común [...] es conferir todo su poder a un hombre o una asamblea de hombres" (Hobbes, 2006, 140). Por su parte, Locke afirma que: "[...] sólo existe sociedad política allí y, allí exclusivamente, donde cada uno de los miembros a hecho renuncia de ese poder natural, entregándolo a manos de la comunidad [...]" (Locke, 2005, 85). Incluso cuando Locke distingue entre pacto de asociación y pacto de sumisión, reconoce, como señala Pierre Rosanvallon, que: "[...] no hay sociedad política o sociedad civil sino allí donde cada uno de los individuos que forman parte de ella se ha desprendido de sus poderes naturales para confiárselos a la comunidad" (Rosanvallon, 2006, 30). La fórmula sintetizada del pacto social para Rousseau es la siguiente: "Cada uno
} 
La elección de una estrategia explicativa dispuesta a racionalizar el poder del soberano haciéndolo pasar por un contrato hipotético, tiene muchas virtudes, pero también límites. Veamos. De todos es sabido que un planteamiento de este tipo pretende reducir complejidades para crear un modelo evaluativo capaz de indicarnos las condiciones que validarían la consolidación de un orden social legitimo y que, por lo mismo, no se interesa en estudiar de forma pormenorizada el ejercicio real del poder. Esa es la ventaja de este tipo de línea argumentativa, bien o mal nos brinda un aparato conceptual normativo para evaluar el presente desde una perspectiva "racional". Sin embargo, si dando un paso atrás, nos preguntamos por las circunstancias efectivas que impiden la realización de ese orden, o si dando un paso adelante, intentamos explicar por qué y cómo subsisten y se reproducen relaciones de poder aún cuando se ha instituido un orden social más o menos legítimo ${ }^{94}$, el modelo contractual tiene poco que decirnos, salvo algunas consideraciones sobre la naturaleza pasional del hombre o la alusión a teorías de la acción racional basadas en el concepto de interés ${ }^{95}$. Ambos elementos, sin embargo, resultan totalmente insuficientes

de nosotros pone en común su persona y todo su poder bajo la suprema dirección de la voluntad general, recibiendo a cada miembro como parte indivisible del todo" (Rosseau, 2002, 15).

${ }^{94}$ En El capitalismo utópico Pierre Rosanvallon muestra con claridad que las teorías del pacto social no dan respuesta a dos problemas: 1) una vez legitimada la institución de la sociedad, el modelo contractual no explica la forma en que se regularía la paz y la guerra entre distintas naciones, y 2) El modelo contractual no explica cómo se regularían los conflictos una vez instituida la sociedad. Rosanvallon muestra que la inserción del mercado en el vocabulario político del siglo XVIII se volvió tan efectiva porque permitía solventar esas dificultades. La noción de mercado permitía defender la idea de que las relaciones entre Estados podían generar un juego de suma positiva para ambas naciones, por el otro lado la idea de mercado alienta la visión de que las necesidades y los intereses pueden regular el espacio social (Rosanvallon, 2006, 7ss).

${ }^{95}$ De Hobbes a Kant, las explicaciones del conflicto humano son del todo insuficientes, ya sea que se caracterice al hombre como un ser competitivo, desconfiado y anhelante de gloria (Hobbes, 2006, 101ss), ya sea que se apele a una naturaleza corrompida en algún momento del proceso de socialización (Rousseau, 2010, 64ss) o a una insociable sociabilidad que le sería inherente (Kant, 2006 B, 46), en todos los casos se soslayan las determinaciones efectivas que históricamente generan mecanismos de conflicto específicos absolutamente racionales, que en su concreción real definen la posición del hombre ante los otros y ante sí mismo. De igual forma, la transformación del vocabulario político hacia las nociones de interés, trabajo, industriosidad, etc., que va de Mandeville a Smith, pasando por Helvecio y Hume ( $C f r$, Rosanvallón, 2006,41ss); (Hirschman, 1978, 45ss), poco aporta al conocimiento efectivo de las relaciones de poder. En cambio, genera un modelo racional de sujeto que, a cambio de reducir las complejidades para erigir un 
para entender mecanismos tan complejos como las disciplinas, el funcionamiento del poder psiquiátrico, la medicalización de la sociedad, el surgimiento de la biopolítica y otros fenómenos sociales que, en nuestros días, resultan sumamente importantes y de los que, en el plano histórico concreto, surgen saberes, formulaciones legales, formas de subjetividad, etc. $^{96}$

Foucault cree que los planteamientos que usan el modelo del contrato suponen, al menos, dos ideas problemáticas en lo tocante a su concepción del poder. Por un lado, afirman que la constitución de un soberano legítimo remite a un contrato en el que el poder se transfiere de unas manos a otras, como si éste fuera una posesión capaz cederse. Por el otro, sostienen directa o indirectamente que el poder adquiere dimensión política únicamente cuando pasa por el cuerpo del soberano. No importa que la soberanía radique en un monarca, un parlamento o una voluntad general, una vez que los gobernados transfieren su poder por la vía contractual éste se vuelve el monopolio de un solo agente. Foucault insiste una y otra vez en la insuficiencia de esta postura - que podríamos denominar sustancialistapues reduce la multiplicidad de las manifestaciones del poder a la posesión de un superior sobre sus súbditos. El poder, así concebido, no sería sino un atributo, una fuerza amorfa, capaz de intercambiarse mediante un acuerdo voluntario que lo revestiría de legitimidad ${ }^{97}$.

modelo de análisis "racional", nos ofrece una explicación débil de las verdaderas condiciones de los conflictos existentes y las relaciones de fuerza dominantes.

${ }^{96}$ Se podría argumentar que el modelo jurídico no se ocupa de las relaciones de poder porque no es esa su intención, el francés sabe que el objetivo central del modelo contractual no es explicar el flujo efectivo de las relaciones de poder, pero no lo es porque este problema se encuentra resuelto de antemano. La consecuencia lógica de un planteamiento contractual es pensar que una vez generado un acuerdo entre las partes el poder, en tanto se supone como una suerte de substancia intercambiable, si no desaparece, al menos se vuelven legítimo en su totalidad.

${ }^{97}$ Por ello, en el seminario de 1976 Foucault plantea que sus análisis han pretendido problematizar el asunto del poder desde una dimensión distinta a la del modelo jurídico. Esto porque su intención no es justificar racionalmente los mecanismos que erigirían legítimamente al "poder soberano en lo alto", ni explicar "cómo, a partir de la multiplicidad de individuos y las voluntades, puede formarse una voluntad o un cuerpo únicos, pero animados por un alma que sería la soberanía" (DS, 37). 
El problema de esta concepción es que difumina todas las diferencias posibles, se desentiende de las formas específicas de su ejercicio y lo identifica con la relación binaria entre poseedores y no poseedores:

[...] el poder, salvo si se le considera desde muy arriba y muy lejos no es algo que se reparte entre quienes lo tienen y lo poseen en exclusividad y quienes no lo tienen y lo sufren, el poder, creo, debe analizarse como algo que circula o, mejor, como algo que solo funciona en cadena. Nunca se localiza aquí o allá, nunca está en las manos de algunos, nunca se apropia como una riqueza o un bien. El poder funciona. El poder se ejerce en red $\mathrm{y}$, en ella, los individuos no sólo circulan sino que están siempre en situación de sufrirlo y también de ejercerlo. Nunca son el blanco inerte o consintiente del poder, siempre son sus relevos. En otras palabras, el poder transita por los individuos, no se aplica a ellos (DS, 38).

Ahora bien, Foucault cree que, en lo esencial, el modelo marxista comparte estos supuestos con la teoría de la soberanía. Ello explica la incorporación de ambas visiones en un solo modelo. En efecto, la suposición del poder como algo intercambiable jurídicamente es paralela a la idea de que una clase puede arrebatarle el poder a otra, y la idea de que existe un agente -en este caso el Estado representado por un soberano- que posee el monopolio del poder, puede homologarse con la idea de que una clase social posee el poder de forma unilateral. Por último, el francés señala que tanto el paradigma marxista como el modelo jurídico fundado en la soberanía coinciden en la remisión a fenómenos de carácter económico en su intento por acercarse al poder. En el caso del marxismo esto sucede porque el poder político le debe su existencia a las relaciones económicas y en el caso del modelo jurídico porque identifica su ejercicio con una operación de intercambio de bienes: "En términos generales tenemos [...] en un caso, un poder político, que encontraría su modelo formal en el procedimiento del intercambio, en la economía de la circulación de los 
bienes; y, en el otro, el poder político tendría en él su razón de ser histórica y el principio de su forma concreta y su funcionamiento actual" (DS, 27).

Desde principios de la década de los 70's Foucault comprendió que un análisis pormenorizado del poder debe alejarse del modelo jurídico. Dicho modelo es incapaz de explicar cómo ciertas prácticas específicas inciden en las conductas de los sujetos, fomentan regímenes de saber particulares, apoyan el funcionamiento de ciertos mecanismos institucionales ${ }^{98}$, etc., y en cambio, nos otorga una imagen bastante limitada del conflicto social y de sus causas. Ahora bien, tanto el desarrollo de las conductas subjetivas, como de los regímenes de verdad y de los mecanismos institucionales, transforman, en los hechos, la correlación entre sujeto, objeto y mundo y, por lo mismo, definen nuestro presente. De ahí que, para Foucault, explorar las condiciones de posibilidad de las prácticas de poder es parte de un análisis filosófico destinado a hacer inteligible el orden que permite la constitución política del sujeto ${ }^{99}$. Se ve con claridad que a un proyecto con tales

98 Ahora bien, esas formas de subjetividad que entran en relación con saberes e instituciones, como los regímenes de verdad y los mecanismos que soportan ciertas prácticas institucionales son, según Foucault, rasgos ontológicos de nuestro presente, por lo mismo analizar las condiciones que las hacen posibles es, según el último Foucault, una labor propiamente filosófica. Si es verdad que en 1976 el francés se desmarca explícitamente de lo que él llama "papel tradicional de la filosofía política" (el cual, según él, consiste en mostrar las condiciones que le darían legitimidad al poder político estableciendo los límites que el derecho debe imponerle: "Esquemáticamente, digamos esto: existe una cuestión tradicional que es, creo, la de la filosofía política y que podríamos formular así: ¿cómo puede el discurso de la verdad o, simplemente la filosofía entendida como el discurso de la verdad, fijar los límites de derecho del poder"[DS, 34]), también lo es que el análisis de las condiciones que le brindan consistencia ontológica a la realidad, debe ser considerado un trabajo filosófico. En varias ocasiones Foucault negó que su trabajo se adscribiera al papel tradicional de la filosofía política, sin embargo en otras admitió que su labor puede relacionarse con la filosofía porque, en el fondo, intenta analizar la "política de la verdad"; es decir, las condiciones que hacen posible que la verdad emerja en la historia de la manera que lo hace. Foucault es consciente de que sus análisis pueden ser catalogados como estudios sociológicos, pero afirma claramente que su trabajo no es el de un sociólogo, ni el de un historiador: "[...] lo que hago, en resumidas cuentas, no es ni historia, ni sociología, ni economía. Es algo que, de una u otra manera, y por meras razones de hecho, tiene que ver con la filosofía [...] Se trata de la política de la verdad" (STP, 17).

${ }^{99}$ Si la ontología es, ante todo, el estudio de los principios que fundamentan el "Ser", analizar las condiciones que hacen que el presente sea lo que es y no otra cosa es, según el francés, llevar a cabo una "ontología del presente"; esto es, un análisis de los principios y los fundamentos de lo real. En la medida que esa ontología 
pretensiones no le es productiva una concepción de poder sustancialista. Para llevar a cabo su objetivo, el francés tenía que buscar otras vías de análisis. Esta es, sin duda, la meta que persigue durante la primera mitad de la década de los 70's, Vigilar y castigar es, en buena medida, el resultado de su intento por desprenderse del modelo jurídico. En dicho texto, el francés establece con claridad las vías de desmarque respecto a ese modelo: frente a la caracterización del poder como una sustancia capaz de poseerse y transferirse, opone la célebre formulación de que el poder "se ejerce más que se posee" (VC, 33), con lo cual abre la puerta para un estudio que no encuentra la esencia de las relaciones de poder en la forma de la ley y el contrato, sino en sus estrategias y su mecanismos ${ }^{100}$ peculiares. Esto es, en sus prácticas concretas y, por ende, en sus efectos reales. Frente a la afirmación de que el poder era resguardado por un agente privilegiado -llámese Estado, soberano o clase dominante-, esgrime la hipótesis de que el poder circula "hondamente en el espesor de la sociedad" (VC, 34), con lo cual abre la puerta para una microfísica del poder, la cual, en vez de identificar el poder con un orden centralizado único, explora los distintas estratos y las distintas figuras que adquiere. Por último, frente a la reducción del poder a un modelo contractual, Foucault opuso el modelo de la batalla: "El estudio de una microfísica supone [...] que [al poder] se le dé como modelo la batalla perpetua más que el contrato que opera una cesión" (VC, 339). Esta última oposición es crucial. En 1975 -año en que se publica Vigilar y castigar-, el francés cree que, ante la insuficiencia del modelo jurídico, la única vía para comprender el desenvolvimiento de las relaciones de poder consiste en concebirlas en los términos de una lucha constante. Sin embargo, en el seminario de 1976 el autor

tiene la intención de mostrarnos cuales son las condiciones prácticas que hacen que los sujetos sean lo que son -recordemos que, para el francés estos sujetos entran en relación con otros sujetos y con objetos del mundo y, al hacerlo, los transformen en el mismo movimiento en que ellos se transformen-, en la medida, decíamos, que esa ontología intenta discernir los principios que explican que el sujeto sea lo que es, estamos hablando de una "ontología de nosotros mismos" ( $C f r$, QI, 986).

${ }^{100}$ (Cfr, VC, 33ss). 
comienza a notar las limitaciones de esa posición, y muy pronto -en 1978-, se deslinda por completo de ella. Veamos ahora cuales son las características de éste modelo y qué razones llevaron a Foucault a alejarse del mismo. .

\subsection{3.- El modelo de lucha y represión}

\subsubsection{1.- La hipótesis represiva}

En la segunda clase del seminario de 1976, Foucault afirma que desde principios de los 70’s comprendió la necesidad de abandonar el modelo jurídico debido a sus escasos rendimientos teóricos para analizar las relaciones de poder, pero constató que, al hacerlo, le restaban pocos instrumentos conceptuales. En efecto, una vez negada la posición que pretende reducir las cosas a un fenómeno económico sólo le restaba una afirmación provisional: "[...] el poder no se da ni se intercambia, ni se retoma, sino que se ejerce y sólo existe en acto" (DS, 27). Sin embargo, esta afirmación resulta insuficiente; el propio Foucault pone en la mesa los cuestionamientos obvios que este planteamiento despierta: “[...] si el poder se ejerce, ¿qué es ese ejercicio? ¿En qué consiste? ¿Cuál es su mecánica?” (DS, 28).

Para 1976, la única respuesta que el francés había logrado concebir era la siguiente: “el poder no es, en primer término mantenimiento y prórroga de las relaciones económicas, sino, primariamente, una relación de fuerza en sí misma” (DS, 27). Ahora bien, la concepción de poder como fuerza puede adoptar dos formas: la de la represión, o la de la guerra. En efecto, si se asume que el poder es una fuerza, debe aceptarse que el efecto primordial de la misma es reprimir; es decir, limitar las posibilidades de quienes la reciben. Pero, por otro lado, también es posible afirmar que esa fuerza se enfrenta incesantemente 
con otras fuerzas, de esta afirmación se sigue que la diferencia en el lugar jerárquico de las mismas depende de los resultados de sus infinitos enfrentamientos. La primera de estas vertientes es llamada por el francés "hipótesis represiva”, la segunda, en clara alusión al filosofo alemán, "hipótesis Nietzsche”.

Iniciemos analizando la primera. Desde un principio, Foucault desechó la hipótesis represiva por una razón fundamental; a saber, dicho modelo nos ofrece una caracterización meramente negativa del poder. En efecto, si el poder es esencialmente represión, debemos admitir que, en el fondo, se presenta como una restricción. Para esta perspectiva, el poder sería una fuerza capaz de generar elisiones y trazar fronteras, por lo que: "sus efectos [únicamente se presentarían en] la forma general del límite y la carencia” (HS1, 101).

En 1976, Foucault publica el primer volumen de Historia de la sexualidad. Si a nivel conceptual Vigilar y castigar puede ser considerado como un desplazamiento del modelo jurídico, es posible, a su vez, considerar este libro como una crítica directa al modelo represivo. En lo esencial, el primer volumen de Historia de la sexualidad busca replantear el problema de la relación entre sexualidad, poder y saber más allá del modelo represivo, esto implicaba analizar la emergencia de la sexualidad en su singularidad histórica desde una perspectiva genealógica. Para ello, Foucault tuvo que tomar distancia de una corriente de interpretación del fenómeno sexual muy vinculada a lecturas de corte psicoanalítico, en especial debió alejarse de estudios como los de Wilheim Reich. Este último sostenía que la burguesía victoriana propició una cruzada represiva contra la sexualidad desde el siglo XVII. Al localizar la prohibición del sexo en ese periodo histórico, resultaba sencillo 
vincularla con el origen del capitalismo ${ }^{101}$ y explicar su censura como una imposición burguesa tendiente a economizar las energías de la fuerza de trabajo ${ }^{102}$. Según tal lectura, sólo habríamos empezado a liberarnos de esa cruzada gracias a la puesta en discurso del sexo iniciada por Freud ${ }^{103}$. El francés cree que esta perspectiva se puede autoproclamar liberadora porque caracteriza el poder sobre el sexo como represión, de tal manera que bastaría con nombrarlo, hablar de él, ponerlo en discurso, para estar por encima del poder. De ahí la supuesta subversión de todos aquellos que simplemente diciendo la palabra sexo, creen superar toda cadena y toda atadura. Frente a semejante posición -sin duda habitual en los 70’s- Foucault lanza una pregunta simple: "la mecánica del poder y en particular la que está en juego en una sociedad como la nuestra ¿pertenece en lo esencial al orden de la represión? ¿La prohibición, la censura, la denegación son las formas según las cuales el poder se ejerce de un modo general $[\ldots]$ ? (HS1, 17).

El autor de Vigilar y castigar considera que no. Por lo mismo, decide abordar las cosas de otra manera: en vez de comprender la relación entre poder y sexualidad a través de la lógica negativa de la censura y la prohibición, apuesta por explorar la complejidad histórica de este vínculo en su positividad $^{104}$. En efecto, si verificamos con detenimiento los procesos históricos reales, nos daremos cuenta de que el poder produce y genera ciertas prácticas, ciertos discursos, ciertos efectos de realidad. Las circunstancias históricas reales a las que se acostumbra remitir la idea de un sexo reprimido son más complejas de lo que aparentan a

\footnotetext{
${ }^{101}$ En una dirección semejante se halla, según Foucault, el texto de Marcuse Eros y civilización. Al respecto véase (LA, 220ss).

${ }^{102}$ (Cfr, HS1, 10ss).

${ }^{103}$ (Cfr, HS1, 7-23).

${ }^{104}$ No porque sea algo bueno, más bien porque no se limita a reprimir o prohibir, sino que también produce realidad. Al respecto véase la entrevista con M. Fontana titulada "Verdad y poder", en la que dice: "[...] me parece que la noción de represión es totalmente inadecuada para dar cuenta de lo que precisamente hay de positivo en el poder" (OE, 385).
} 
primera vista. A partir del siglo XVII, la sexualidad no fue únicamente prohibida; hubo también una producción discursiva, una incitación cada vez más grande y un vocabulario específico para hablar del sexo, a tal punto que ya en el siglo XIX nos encontramos con un nuevo dominio de realidad en cuyo centro se debate una preocupación médico-jurídica hasta antes impensable ${ }^{105}$.

La hipótesis represiva parte de un supuesto que, como vimos en el capítulo anterior, Foucault no puede aceptar; a saber, se funda en la creencia de que existe algo llamado sexualidad a lo que, posteriormente, unas fuerzas ajenas vendrían a limitar. La necesidad metodológica de no presuponer al objeto o al sujeto antes de cualquier práctica, hace que nuestro filósofo aborde las cosas desde una atalaya distinta; en lugar de suponer la existencia de algo como la sexualidad, se pregunta cómo es que ésta pudo ser producida como objeto de discurso y como objeto de prácticas efectivas en el mismo movimiento en el que se generaban sus propios límites, sus normas y sus formas de acceso. Pero este cambio de perspectiva no sólo obedece a las necesidades epistemológicas de la postura del francés, sino más bien a una exigencia que el propio proceso histórico le demanda, pues si observamos el despliegue de relaciones específicas que permitieron la emergencia de un objeto llamado sexualidad, debemos admitir que la única manera de defender la hipótesis represiva es encajonando indiferenciadamente una multiplicidad de fenómenos sumamente compleja bajo el concepto de prohibición. Pongamos un ejemplo. A finales del siglo XVIII comienza a aparecer eso que Foucault llama la "familia de los perversos". Anteriormente, el problema de los delitos sexuales era abordado únicamente desde una lógica jurídica, pero a partir de los últimos años del siglo XIX eclosiona toda una literatura peculiar. Se trata de

${ }^{105}$ (Cfr, HS1); (Davidson, 2004). 
una nueva realidad generada por el discurso médico, el cual ya no funciona instaurando una división binaria entre delincuentes y no delincuentes; ahora, por el contrario, produce todo un saber que, entre otras cosas, intenta descubrir la razón de ser, el secreto y las causas más profundas de "enfermedades" y "desviaciones". En cosa de unos años, los juristas no sólo se enfrentan al fenómeno más o menos homogéneo de los delincuentes sexuales, también se las tienen que ver con los "exhibicionistas" de Laségue, los "fetichistas" de Bidet, los "zoofilos y zooerastas" de Krafft-Ebing, los "automonosexualistas" de Rohleder, los "mixoesxopófilos", los "ginecomastas", los "presbiófilos", los invertidos "sexoestéticos", las "dispareunistas", etc. Todas ellas son producciones práctico-discursivas que permitieron circunscribir, delinear y conducir a los sujetos, ya no calificándolos por su transgresión a la ley, sino indagando su interioridad, su identidad última, su composición corporal, su historia, etc. ${ }^{106}$ De inmediato se observa que semejante proceso no puede ser analizado suficientemente afirmando que hubo una restricción de la sexualidad, sin duda hubo prohibiciones y restricciones pero la propia realidad -no el capricho de Foucault- nos obliga a dar un paso adelante si queremos comprender ese fenómeno en su especificidad.

De hecho, la inserción del problema sexual en el vocabulario médico permitió la constitución de una serie discursiva totalmente novedosa y, al mismo tiempo, generó una realidad específica ${ }^{107}$ con sus ámbitos de análisis, sus espacios de acción, sus formas de interpretación, sus repercusiones en la subjetividad real de individuos insertos en determinados campos discursivos, etc. Este punto nos coloca de lleno frente a un tema que ya hemos mencionado: la relación entre poder y saber. Decir que el poder es correlativo a

\footnotetext{
${ }^{106}$ (Cfr, HS1, 48-64).

${ }^{107}$ (Cfr, Ibid); (Davidson, 2004, 65ss).
} 
la verdad no es una frase ocurrente del francés, es un hecho que debemos tomarnos en serio si queremos comprender los procesos que constituyen nuestra subjetividad y, dado el caso, las formas que nos permitirían desasirnos de ciertas prácticas que imposibilitan nuestra autodeterminación. En el caso que en este momento nos incumbe ${ }^{108}$, debemos afirmar que la emergencia de un nuevo ámbito de veridicción como la sexualidad dio como resultado una nueva normatividad capaz de circunscribir a los sujetos, ordenar sus esferas de influencia y conducir sus actividades sexuales ${ }^{109}$.

En suma, la Voluntad de saber es, entre otras cosas, un intento de mostrar que el surgimiento de la sexualidad supone la aparición de toda una red de discursos, una preocupación médica, un análisis científico, una reconceptualización jurídica, etc. Esta singularidad histórica, no puede entenderse únicamente bajo la lógica de la represión. No sólo se reprimió un deseo que estaba depositado ahí desde el principio de los tiempos, sino que se generó un discurso ${ }^{110}$, un vocabulario y una normatividad específica sobre el sexo, que indujo comportamientos, saberes, instituciones, etc. Por lo mismo, a Foucault le parece imprescindible abandonar el modelo represivo para concebir el poder en lo que tiene de

\footnotetext{
${ }^{108}$ Es necesario aclarar que la vinculación entre poder y saber es un postulado que atraviesa toda la obra de nuestro filósofo, aun cuando en sus primeras obras no evidencia esta conexión; sin embargo ya en El orden del discurso (OD, 15ss) y sobre todo en Vigilar y castigar (VC, 34) esta tesis se sostiene como uno de los pilares de los estudios foucaultianos.

${ }^{109}$ Tomemos el ejemplo de la creciente red de vigilancia contra las prácticas onanísticas de los jóvenes en el siglo XIX. De entre toda la literatura al respecto podemos elegir el famoso Livre sans titre publicado en 1830 repleto de "páginas en las que se analizan todas las consecuencias desastrosas de la masturbación y [...] la fisonomía cada vez más descompuesta, estragada, esquelética y diáfana del joven masturbador que se agota. Esta campaña entraña igualmente instituciones destinadas a atender o curar a los masturbadores, prospectos de medicamentos, llamados médicos que prometen a las familias curar a sus hijos de ese vicio" (LA, 219). El poder no sólo actúa al prohibir la actividad masturbatoria juvenil, sino que sus relaciones también son las condiciones que hacen posible la inserción, hasta antes inexistente, del problema sexual en términos de verdad científica.

110 "Lo importante es que el sexo no haya sido únicamente una cuestión de sensación y de placer, de ley o de interdicción, sino también de verdad y de falsedad, que la verdad del sexo haya llegado a ser algo esencial, útil o peligroso, precioso o temible; en suma, que el sexo haya sido constituido como una apuesta en el juego de la verdad" (HS1, 71).
} 
productivo: “[...] más que de una represión generalizada [...] hay que partir de esos mecanismos positivos, productores de saber, multiplicadores de discursos, inductores de placer y generadores de poder; hay que partir de ellos y seguirlos en sus condiciones de aparición y funcionamiento" (HS1, 92). Por último, es necesario señalar que la necesidad de considerar el aspecto afirmativo del poder, no debe entenderse como la aplicación de un modelo de interpretación preconcebido a un fenómeno social concreto, sino como una demanda que la propia realidad histórica le impone al francés para comprender a cabalidad un proceso de consolidación de un fenómeno peculiar. No nos enfrentamos a la implementación de un modelo de análisis sociológico, llámese funcionalismo, teoría de sistemas, configuracionismo, etc., sino del seguimiento específico de una serie de mecanismos en sus "condiciones de aparición y funcionamiento".

\subsubsection{2.- La hipótesis Nietzsche}

Llegado a este punto, un lector atento podría reprocharle a nuestro autor, con toda razón, lo siguiente: "Sí, sí, el poder no es ni una sustancia intercambiable, ni un objeto que detenta una clase o un soberano y que propaga a los estratos inferiores, tampoco es una relación de mera represión y prohibición; sí, efectivamente, el poder circula, se encuentra en todos los planos de la sociedad, es positivo y no excluye al saber. Lo hemos entendido, pero, señor Foucault, usted no nos ha dicho todavía qué entiende por poder". Este problema de conceptualización es crucial y, en buena medida, es la causa de gran número de confusiones y malentendidos sobre la supuesta "Teoría del poder" foucaultiana. En el seminario de 1976, luego de mostrar las limitaciones de cada uno de los modelos anteriores, Foucault afirma que hasta ese momento había intentado darle contenido al concepto de poder 
asumiéndolo en los términos de la guerra y la lucha ${ }^{111}$. A esta perspectiva, Foucault le da el nombre de "hipótesis-Nietzsche"112 y corresponde a la segunda forma que puede tomar la noción de poder cuando es concebido como una fuerza.

El oriundo de Poitiers nos dice que esta hipótesis podría resumirse en la inversión del conocido aforismo de Clausewitz: "la guerra no es más que la continuación de la política por otros medios". En este caso se afirmaría: "la política no es más que la continuación de la guerra por otros medios". Esto querría decir primordialmente "que las relaciones de poder [...] tienen esencialmente por punto de anclaje cierta relación de fuerza establecida en un momento dado, históricamente identificable, en la guerra y por la guerra” (DS, 29). Pero esta hipótesis va más allá, pues sostiene que incluso si se admite que la política tiene como una de sus principales funciones detener la guerra e instaurar un orden social: " [...] el papel del poder político [consiste en] reinscribir perpetuamente esa relación de fuerza, por medio de una especie de guerra silenciosa, y reinscribirla en las instituciones, en las desigualdades, en el lenguaje, hasta en el cuerpo de unos y otros" (DS, 29). Así, el poder no sería otra cosa que la incesante confrontación de fuerzas que subyace a toda relación social, incluso si ésta se encuentra institucionalizada. La paz sería únicamente una máscara que esconde tras de sí las infinitas fuerzas de la guerra. En lo esencial, la "hipótesis Nietzsche" puede caracterizarse de la siguiente forma: dado que el poder se presenta como una fuerza que circula en todos los niveles de la sociedad, es inevitable que ésta se enfrente a otras fuerzas; el resultado de este encuentro sólo puede conceptualizarse en los términos

\footnotetext{
111 (Cfr, DS, 28ss).

112 Dice Nietzsche: "El «desarrollo» de una cosa, de un uso, de un órgano es [...] la sucesión de procesos de avasallamiento más o menos profundos, más o menos independientes entre sí, que tienen lugar en la cosa, a lo que hay que añadir las resistencias utilizadas en cada caso para contrarrestarlos" (Nietzsche, 2006, 129).
} 
de la batalla, la lucha y la guerra.

En la primera mitad de los años 70's, influenciado por sus lecturas de Nietzsche, Foucault asumió esta postura. Por ejemplo, en el famoso texto "Nietzsche, la Genealogía, la Historia” de 1971, el francés señala:

La humanidad no progresa lentamente, de combate en combate, hasta una reciprocidad universal en la que las reglas sustituirán para siempre a la guerra; instala cada una de estas violencias en un sistema de reglas y va así de dominación en dominación.

$\mathrm{Y}$ es justamente la regla la que permite que se haga violencia a la violencia, y que otra dominación pueda doblegar a aquellos mismos que dominan (MP, 18).

En un primer momento, Foucault retomó esta hipótesis porque, de una u otra manera, le permitía dar salida a las limitaciones de los modelos anteriores. En efecto, concebir al poder como guerra no implicaba que éste fuera la posesión de un soberano o una clase, sino el combate infinito entre elementos que, sin cesar, se entrecruzan; tampoco lo reenviaba de inmediato a una relación contractual, sino a las múltiples estrategias que se utilizan para obtener la victoria en una batalla; por último, pensar al poder en términos estratégicos le permitía considerar su aspecto positivo, no era una ley la que, en todos los casos, se imponía a los sujetos para coartar su libertad, sino una serie de técnicas, un conjunto de saberes puestos en marcha en prácticas disímiles que siempre se reinventan.

Ahora bien, en la segunda mitad de los 70's Foucault comienza a comprender que, en su intento por salir del modelo jurídico, había tomado prestado un esquema que, en cierta medida, resultaba igual de "tosco". Para decirlo con una metáfora de Thomas Lemke: “[...] 
al rechazar el modelo jurídico y adoptar su opuesto, Foucault [...] en lugar de "decapitar al rey" ponía patas arriba la concepción que criticaba reemplazando la ley y el contrato por la guerra y la conquista" (Lemke, 2006, 7). Expliquemos con detenimiento esta afirmación, el francés había denunciado el modelo jurídico por circunscribir el problema del poder a la unidad del cuerpo soberano pues, en última instancia, esta operación terminaba generando una noción substancial del poder que no daba cuenta de la multiplicidad de sus relaciones efectivas. Pero para desplazarse de dicha posición el filósofo francés tomó prestado un modelo que, en otro sentido, también simplificaba la idea de poder. Esto por lo siguientes motivos. Si bien es cierto que, como vimos, este modelo le permitía salir del esquema del contrato y concebir el poder tanto en su diversidad estratégica, como en su positividad, también es verdad que la finalidad de todas esas estrategias se concebía en los términos de la conquista y el dominio. Por lo mismo, la diferencia entre opresores y oprimidos terminaba por reducirse a una cuestión de fuerza y no de forma ${ }^{113}$. Con base en estas dificultades, los críticos podían deducir sin mucha dificultad una conclusión problemática que formulaban así: si el poder es una lucha de fuerzas su despliegue se confunde con el de una voluntad irracional que actúa a espaldas de las decisiones racionales de los sujetos.

En efecto, decir que el poder funciona bajo la estructura de la guerra tiene al menos tres inconvenientes. El primero consiste en lo siguiente: el modelo bélico tiende a ocultar la variedad de los objetivos del poder limitándolos a la conquista y la lucha. El segundo podría formularse de la siguiente manera: al asumir que las posibles resistencias al poder no son más que fuerzas cuantitativamente menores, pero no cualitativamente distintas, se puede llegar al extremo de sostener que todo lo que existe son relaciones de poder. De tal

${ }^{113}$ (Cfr, Castro, 2010, 22-23). 
manera que la diferencia entre lo legítimo y lo ilegítimo, lo justo y lo injusto, no serían el resultado de ninguna distinción racionalmente justificable, sino de la prevalencia de una fuerza sobre otra ${ }^{114}$.

El tercer inconveniente deriva del anterior, si la justicia, y en general, todo criterio de legitimidad no es justificable en términos de una razón ajena a las relaciones de poder, sino que, por el contrario, es un efecto de las mismas, resulta posible inferir que el poder es una fuerza contraria a la razón. Habrá que volver sobre esta idea más adelante, por ahora vale la pena rescatar los tres puntos problemáticos que subyacen a una concepción del poder en los términos de la guerra y la lucha, a saber: la unificación del objetivo de su ejercicio, la imposibilidad para diferenciar criterios que provoca su presencia, y la presunta irracionalidad de su proceder.

Si es verdad que en más de una ocasión Foucault afirmó explícitamente que el poder debía concebirse como una relación de lucha y combate ${ }^{115}$, también lo es que en ninguno de sus libros y de sus investigaciones concretas adoptó un esquema de trabajo que se apegara

\footnotetext{
${ }^{114}$ En efecto, Foucault coquetea con esta postura durante un breve periodo. En una famosa discusión con Chomsky dice lo siguiente: "Déjeme que sea un poco nietzscheano [...] me parece que la idea de justicia fue inventada y puesta en práctica en diferentes tipos de sociedades en tanto que instrumento de un determinado poder político y económico, o como arma contra ese poder. Pero me parece que de todas formas la noción misma de justicia funciona en el interior de una sociedad de clase como reivindicación hecha por la clase oprimida y como justificación por parte de los opresores" (OE, 424). Sin duda, la afirmación de Foucault no es del todo desechable, pero siempre es posible contrarrestarla calificándola como deudora de la falacia naturalista. Esta última pretende mostrar que el ser no puede equipararse con el deber ser. En este caso podría decirse que no porque, en los hechos, la justicia haya sido usada históricamente como instrumento de poder, podemos afirmar categóricamente que es imposible diferenciar una idea de justicia que cumple ciertos criterios racionales más satisfactoriamente de otra que no los cumple. Ahora bien, se podría defender la postura de Foucault afirmando que en el mismo movimiento histórico se generan relaciones de poder que estructuran los criterios racionales de validez, con lo cual no serían excluyentes las unas de los otros. En este periodo de la obra foucaultiana esto no se ve de manera clara. Esta postura será defendida cuando hablemos de la reinterpretación que el francés hace de sus trabajos sobre el poder en la segunda mitad de los 70's, pues, según nuestra interpretación, tal perspectiva es completamente justificable en dicho periodo.

${ }^{115}$ (Cfr, VC, 33); (MP, 7-31).
} 
estrictamente a esos señalamientos. En ningún caso sus investigaciones tendieron a analizar el poder como una fuerza irracional; de hecho, en todos sus estudios se ve con claridad que las condiciones que posibilitan ciertas relaciones de asimetría son conceptuadas en los términos de una racionalidad que se constituye al momento de operar en la realidad. En ninguno de los casos los objetivos de las estrategias de poder se reducen a la conquista o a la dominación sin más, sino a finalidades bien específicas como la productividad de los cuerpos, su inserción en campos de estudio, su medicalización, etc. Podemos afirmar que la deficiencia de la concepción del poder no se hallaba tanto en los estudios históricos que quizá de forma muy intuitiva Foucault realizaba, sino en la manera en que intentaba estructurar y conceptualizar su esquema de análisis para hacérselo inteligible a sí mismo y a sus lectores.

Ahora bien, ya en las primeras clases del seminario de 1976, el francés comienza a cuestionar aquella noción que concibe el poder en términos de batalla y combate. En dicho seminario, Foucault pone en duda semejante hipótesis y sugiere la necesidad de salir de ella. Acepta que sus trabajos previos estaban signados por esa forma específica de abordar el problema del poder, pero comienza a desplazarse de la misma: "Está claro que todo lo que les dije en los años anteriores se inscribe del lado del esquema de lucha/represión [...] Ahora bien, a medida que lo hacía, me veía obligado, de todas formas, a reconsiderarlo [...] porque creo que las nociones de represión y guerra deben reconsiderarse notablemente o, en última instancia abandonarse" (DS, 30).

A nuestro entender, el gran problema de las nociones de lucha, batalla y guerra, es que no expresan adecuadamente la mediación racional que toda relación de asimetría requiere para 
existir y subsistir. En efecto, desde Historia de la locura, el trabajo del francés intentó mostrar las relaciones de poder y saber desde la que se construyen los ámbitos de acción en los que el sujeto participa. Ahora bien, esta forma de investigación partía de una intuición que Foucault tardo mucho en conceptualizar de manera adecuada; a saber, los mecanismos de sujeción son contiguos a los mecanismo de racionalidad. La razón es, a la vez, productora de consensos e instituciones y reproductora de prácticas de asimetría. En la época del francés, esta postura resultó un tanto novedosa. En general la historia de la filosofía había reproducido la idea de que la razón es una facultad impoluta que se contrapone a las pasiones y los intereses. Esta interpretación concibe que, en esencia, el poder es ajeno a la razón y la razón sustancialmente distinta del poder. Para salir de esta postura dicotómica, Foucault enfatizó el papel del poder como constructor de realidad, sin embargo, a los ojos de muchos, la terminología bélica exaltaba más el carácter violento de las prácticas que construyen la realidad, que la relación dialéctica de determinación reciproca entre la razón y el poder.

Foucault ve con claridad los peligros de este lenguaje y, como veremos en el siguiente apartado, lo sustituye por una concepción del poder entendido como gobierno. Esto no implica que el poder no genere luchas, cree conflictos o incite batallas -de hecho lo hace-, sino que esas luchas, esos conflictos y esas incitaciones son los efectos de una relación más compleja que siempre está mediada por formas de racionalidad o, más aún, que son ellas mismas prácticas racionales.

Este último apunte es importante, si consideramos el trabajo de Foucault únicamente a la luz del primer lustro de los setentas, aquellas críticas que le reprochan haber confundido el 
poder con la guerra, la dominación y el avasallamiento, podrían comprenderse. Aunque, por otro lado, la denuncia de limitar el desarrollo de la sociedad en su conjunto al modelo de la batalla y la lucha podría ser bastante discutible. Sin embargo, esta discusión carece de sentido si tomamos en cuenta el desplazamiento que el propio Foucault realiza en la segunda mitad de los setentas. Ya para 1978, el francés se ha desprendido completamente del modelo bélico valiéndose de un par de nociones que serán fundamentales para sus análisis posteriores y para la revisión de su propio trabajo: la de gobierno y la de "gubernamentalidad".

De ahí que las criticas con las que corrientemente se descalifica el análisis del poder foucaultiano terminan siendo insuficientes. Para muestra basta un ejemplo. Quizás el planteamiento más interesante al respecto sea el que Axel Honneth realiza en Crítica del poder. En la página 236 de su texto, el alemán cita una entrevista hecha por Allessandro Fontana a Foucault, en ella éste afirma: "Creo que a lo que debemos referirnos no es al modelo de la lengua y de los signos, sino a la guerra y la batalla. La historicidad que nos lastra y nos determina es belicosa [...]" (Honneth, 2009B, 236). A partir de esta declaración, Honneth deduce una larga serie de consecuencias:

Como fácilmente puede comprobarse en estas afirmaciones, Foucault dibuja aquí los perfiles fundamentales de una teoría del poder social [...] Foucault propondrá un modelo estratégico de poder cuya característica fundamental proviene de la tentativa de traducir la teoría del poder nietzscheano -una concepción de tintes naturalistas- al marco de una teoría de la sociedad [...] Foucault parece apoyar [...] la afirmación, de ciertas resonancias hobbesianas de un originario estado de guerra de todos contra todos (Honneth, 2009B, 236-241).

La lógica del argumento de Honneth es la siguiente: Foucault intenta construir una teoría social alternativa a partir de las herramientas que el modelo nietzscheano le proporciona, 
pero debido a que ese modelo entiende el poder como una fuerza que actúa a un costado o debajo de la razón, termina remitiendo la actividad humana al despliegue de potencias irracionales. Esto porque, según Honneth, el francés debe suponer cierta tendencia a la guerra y al conflicto en la naturaleza de los procesos de socialización humana, para dar cuenta de la estructuración social. Ya en el primer capítulo habíamos clarificado que nuestro filósofo no desea realizar una Teoría social, más allá de esa precisión, vale la pena mostrar que la hipótesis de Honneth no se sostiene desde su punto de partida. Lo que en el fondo le da sustento a todo el argumento del alemán, es el supuesto de que, en su intento por generar una Teoría social, Foucault partió de una concepción nietzscheana, la cual identificaba el poder con la violencia y la lucha de fuerzas. Para mostrar las limitaciones de esta interpretación es necesario entender los conceptos de gobierno y "gubernamentalidad" y la función que cumplen en los trabajos de nuestro autor. Así, podremos dejar de lado esta interpretación -largamente extendida- para valorar seriamente los aportes del francés dentro de la filosofía política.

\section{2.- Gobierno y gubernamentalidad}

A lo largo de este capítulo hemos visto los obstáculos que Foucault enfrentó al momento de analizar los procesos de constitución del sujeto. Ahora bien, debido a estos inconvenientes el francés trató de abrirse un camino de análisis distinto, al margen de las perspectivas habituales que, en su época, definían la manera de pensar el poder. En especial, nuestro filósofo trató de tomar distancia de dos grandes líneas de argumentación: por un lado, intentó alejarse del modelo jurídico-económico ligado a la teoría de la soberanía y, por el otro, se desligó -luego de haber recurrido a ella- de la hipótesis Nietzsche. Para Foucault, el 
enfoque de la teoría del soberano resultaba insuficiente -que no erróneo o falaz- debido a varios motivos. A nivel teórico, el más importante de ellos es el siguiente: si el poder es concebido exclusivamente como el resultado de un acuerdo político se asume que, después de dicho acuerdo, éste -el poder- puede ser poseído por una persona o por un grupo de personas. Ahora bien, si el poder se problematiza en estos términos, resulta imposible dar razón de toda la serie de relaciones de asimetría y sometimiento que subsisten -después de la institución del acuerdo- en las interacciones de todos los agentes sociales, tanto en los que "poseen" el poder como en los que supuestamente no lo "poseen". Por su parte, la hipótesis Nietzsche adolecía de una importante desventaja, identificaba de forma inmediata el poder con la violencia, la batalla y la lucha. El reproche que se le dirigía a esta postura es el siguiente, si el poder es concebido únicamente como "fuerza" bélica, su ejercicio parece depender más de arrebatos irracionales que de acciones racionales.

Sin duda, ambas hipótesis son los extremos de una visión del poder limitada, cuyo máximo defecto es, sin duda, la homogeneidad de su caracterización. En efecto, por un lado la perspectiva jurídica nos remite a un acuerdo racional que vuelve legítima toda relación jerárquica, y por el otro, la hipótesis Nietzsche subordina toda racionalidad al caudal determinado por el desarrollo de fuerzas violentas. Si nos quedamos con estas opciones estaríamos obligados a elegir, de forma maniquea, entre un consenso racional que sólo tiene efectos armónicos y una fuerza irracional que sólo reproduce el desorden, el caos y la falsedad.

Ante este impasse, la única solución viable consiste en cambiar la perspectiva de análisis. En buena medida, estas posturas son problemáticas porque funcionan generando una 
oposición irresoluble entre el consenso y la violencia. Luego de su paso por la hipótesis Nietzsche, Foucault comprende que ningún análisis significativo de las relaciones de poder puede partir de una oposición excluyente como ésta. En 1978 escribe un artículo titulado "El sujeto y el poder", el cual fue escrito como respuesta a una serie de preguntas que Dreyfus y Rabinow le dirigieron al final del libro Foucault: más allá del estructuralismo y la hermenetica ${ }^{116}$. Entre las dudas que ambos académicos le plantearon al entonces profesor del Colegio de Francia, destaca una que por su relevancia teórica merece nuestra atención. Esta duda puede ser planteada en los siguientes términos: una vez que Foucault se ha desprendido de los modelos excluyentes para analizar el poder, una vez que ha establecido que el poder es algo que circula, algo que no puede ser poseído y algo que produce realidades, ¿qué debemos entender por tal?, ¿qué definición nos permitiría salir de esta enumeración de características para lograr identificar una relación de poder? El francés responde a estas preguntas valiéndose de una noción novedosa en su trabajo: la de gobierno ${ }^{117}$. A partir de este concepto generará una concepción teórica que lo alejará por completo de las perspectivas maniqueas anteriores. Veamos en qué consiste.

En "El sujeto y el poder" Foucault hace explicito algo que su adscripción a la hipótesis Nietzsche había velado momentáneamente, a saber: las prácticas de poder no deben confundirse con el consenso o la violencia sin más, deben analizarse como formas de racionalidad destinadas a dirigir las conductas de los otros:

Obviamente la puesta en juego de las relaciones de poder no es más exclusiva del uso de la violencia, que de la obtención del consenso; sin duda, el ejercicio del poder jamás puede ser

\footnotetext{
${ }^{116}$ (Cfr, Dreyfus, Rabinow, 1989).

${ }^{117}$ (Cfr, SP, 1054ss).
} 
tal sin una o sin el otro, a veces sin ambos al mismo tiempo. Pero aunque el consenso o la violencia son los instrumentos o los resultados, ninguno de ellos constituye el principio o la naturaleza básica del poder. El ejercicio del poder puede producir como resultado tanta aceptación como se desee: puede apilar muertos o protegerse detrás de cualquier amenaza que uno se pueda imaginar. En sí mismo el ejercicio del poder no es violencia ni es un consenso que, implícitamente, puede renovarse. Es una estructura total de acciones dispuestas para producir posibles acciones: incita, induce, seduce, facilita o dificulta: en un extremo, constriñe o inhibe absolutamente; sin embargo, es siempre una forma de actuar sobre la acción del sujeto, en virtud de su propia acción o de ser capaz de una acción (DSP, 253).

A primera vista esta definición parece poco original, sin embargo una vez que hemos comprendido el impasse que intenta superar, podemos valorar sus alcances con mucho más precisión. Al afirmar que el poder es una forma de acción capaz de estructurar el campo de acciones posibles de otros, Foucault puede mantener los alcances adquiridos al desplazarse de la teoría jurídica del soberano, del análisis marxista en boga, del modelo represivo y, al mismo tiempo, superar las dificultades que la hipótesis Nietzsche reproducía. En efecto, esta definición supone que las acciones que estructuran otras acciones no son exclusivas de un solo sujeto social, ya sea el soberano, el parlamento o la burguesía; tampoco asume que el poder se puede intercambiar como si fuera una sustancia, pues depende del ejercicio de acciones más que de la posesión de una cosa. Además, al concebir el poder como una acción sobre otras acciones, el francés recupera una idea que, como vimos, consideraba sumamente importante desde Vigilar y castigar: el poder no es meramente una relación negativa. En efecto, las acciones que pretenden dirigir acciones de otros, pueden tomar la forma de la prohibición o la censura, pero también la de la seducción o la inducción; pueden incitar ciertos actos, construir realidades, incentivar discursos, 
promover y delinear las estructuras de acción de los otros, ${ }^{118}$ etc. Por último, se ve con claridad que tal definición está lejos de apelar a una fuerza irracional que, independientemente de los sujetos ${ }^{119}$, determinaría el desarrollo de las relaciones sociales; todo lo contrario, las relaciones de poder son el producto directo de la actividad humana y esa actividad siempre está mediada por la razón, el poder no es independiente de la razón y la razón no es independiente del poder.

Al parecer Foucault comprendió que su adscripción a la hipótesis Nietzsche había generado los principales malentendidos respecto a su proyecto. Por lo mismo, ante la pregunta expresa de Dreyfus y Rbinow sobre qué entiende por poder, el francés afirma que éste no debe buscarse:

[...] du côté d'une violence qui en serait la forme primitive, le secret permanent le recours dernier -ce qui appareít en dernier lieu comme sa verité, lorsqu'il est contraint de jeter la masque y de se montrer tel qu'il est [...] Le pouvoir, au fond, est moins du l'ordre de l'afrontement entre deux adversaires, ou de l'engagement de l'un à l'égard de l'autre, que de l'ordre du «gouvernement» (SP, 1056).

Esta aclaración es sumamente importante, no sólo echa por tierra la crítica de Axel Honneth $^{120}$ recién mencionada, también muestra la insolvencia de aquellos juicios que acusaban al francés de fundar una teoría social a partir de un concepto de poder entendido en los términos de la lucha perpetua. En estas líneas, el francés señala en forma absolutamente clara que el poder no se encuentra del costado de la violencia, que no es el

\footnotetext{
${ }^{118}$ Como veremos en seguida, este desplazamiento hace que Foucault se valga de la noción de gobierno. Jean Terrel afirma que: "Passer ainsi du pouvoir au gouvernement permet d'attirer l'attention sur des pouvoirs dont l'action est de plus en plus positive est de moins en moins negative (Terrel, 2010, 8).

${ }^{119}$ Esta interpretación se puede leer en Walzer y Habermas.

${ }^{120}$ Tomamos como modelo la crítica de Honneth porque desde nuestra perspectiva posee la argumentación más elaborada respecto a los límites de la concepción de poder del francés.
} 
resultado de un impulso "natural" capaz de dirigir el proceso histórico en su conjunto hacia el conflicto permanente. La historia no es la máscara que oculta el eterno confrontamiento civilizatorio. En suma, la hipótesis Nietzsche ha quedado desterrada. Pero al mismo tiempo que se aparta del modelo bélico, el francés introduce las bases para cimentar un edificio conceptual más sólido, el cual descansa en la peculiarísima noción de gobierno.

Antes de explicar con mayor detalle a qué hace referencia el francés cuando habla de gobierno debemos hacer un apunte metodológico importante. Contrario a sus costumbres intelectuales, el francés se vio obligado a dar una definición de poder debido a las preguntas formuladas por Dreyfus y Rabinow, esta definición, sin embargo, no se cierra sobre sí misma; es decir, no establece criterios previos al análisis de la realidad, ni ciñe los objetos estudiados a un molde diseñado con anterioridad. Más que permitirle fundar una "Teoría del poder", el concepto de gobierno le sirve como rejilla de inteligibilidad. Es una construcción analítica que hace visibles ciertos fenómenos históricos específicos. De ahí que el francés hable de una analítica y no de una Teoría ${ }^{121}$, de ahí también, que en vez de dedicarse a la estructuración de un modelo teórico fijo, se preocupe por realizar una conceptualización permanente de las prácticas históricas.

El concepto de gobierno que el francés utiliza para clarificar sus análisis del poder es, en realidad, una rejilla que vuelve inteligibles algunos fenómenos de la vida social, pero son estos fenómenos en su especificidad los que le dan contenido al esquema de análisis y no al revés. Esto no implica que se asuma un "objetivismo" ingenuo, es decir, la idea de que las cosas del mundo nos otorgan de forma transparente el criterio para acceder a los hechos,

${ }^{121}(C f r, \mathrm{HS} 1,100)$. 
sino la afirmación epistemológica de que todo concepto es el resultado de su enfrentamiento con la realidad y sólo podemos dar cuenta de él escudriñando las condiciones históricas que lo vuelven coherente e inteligible en un momento dado. Al respecto dice el francés: "la conceptualisation ne doit pas se fonder sur une théorie de l'objet: l'objet conceptualisé n'est pas seul critère de validité d'une conceptualisation. Il nous faut connaitre les conditions historiques qui motivent tel ou tel type de conceptualisation" (SP, 1043). En ese sentido, Michel Foucault afirma que hablar de poder en términos de gobierno es hablar de poder a la vez en términos históricos y conceptuales $^{122}$. La noción de gobierno no es una invención teórica que deba agregarse a la realidad de forma a posteriori, todo lo contrario, es una construcción conceptual erigida desde la realidad histórica. De ahí que Foucault remita la noción de gobierno a su significación histórica efectiva: "Il faut laisser à ce mot la signification très large qu'il avait au XVI e siècle" (SP, 1056). Para dar cuenta del papel que cumple dicha noción en la revisión y resignificación del proyecto filosófico foucaultiano es necesario, entonces, comprender el sentido que se le daba en el siglo XVI. Veamos.

Para empezar, Foucault revisa algunos textos que abarcan los siglos XIII, XIV, XV y XVI, y muestra que en esos siglos la palabra gobierno hacía alusión:

[...] al desplazamiento en el espacio, al movimiento que se refiere a la subsistencia material, la alimentación, [...] a los ciudadanos que pueden proporcionarse a un individuo y

\footnotetext{
${ }^{122}$ Por lo mismo, resulta necesario dar cuenta de la emergencia histórica de la realidad que mienta el concepto de gobierno para poder entender qué función cumple en el trabajo filosófico del francés. En el caso específico de la filosofía foucaultiana, definir las líneas históricas que configuran la noción de gobierno no es un mero trabajo preliminar, todo lo contrario, este trabajo implica un verdadero esfuerzo filosófico ya que nos obliga a rastrear las condiciones que constituyen nuestra realidad en su desarrollo efectivo, y el proceso de pensamiento que trata de dar cuenta de ella. Analizar el concepto de gobierno es, en suma, analizar la manera en que la propia realidad generó una serie de prácticas discursivas que intentaban dar razón de la misma y dilucidar cómo contribuyeron esas prácticas en la modificación de la realidad.
} 
la salvación que se les puede asegurar, [...] a sí mismo, al ejercicio de un mando, de una actividad prescriptiva, a la vez incesante, afanosa, activa y siempre benévola. Alud[ía] al dominio que se puede ejercer sobre uno mismo y los otros y sobre el cuerpo, pero también sobre el alma y la manera de obrar. Y por último, remit[ía] a un comercio, a un proceso circular o un proceso de individuo que pasa de un individuo a otro (STP, 149).

Esta diversidad de significados posee, sin embargo, un hilo conductor: "Los gobernados, con todo, son gente, hombres, individuos, colectividades [...]. Aquellos a quienes se gobierna son los hombres" (STP, 149). En esencia, cuando en esos siglos se hablaba del arte de gobernar, se hablaba de las técnicas y los procedimientos específicos diseñados para conducir a los hombres hacia un fin deseado. No importando que las técnicas, los procedimientos y, sobre todo, los fines, fueran sumamente diversos. A partir de un breve análisis semántico $^{123}$, el francés muestra que la noción de gobierno implica una acción destinada a la conducción del hombre, la cual define sus formas de ejercicio en función del hombre y sólo del hombre ${ }^{124}$. Para decirlo de forma clara, gobernar no es administrar un territorio, no es dilucidar sobre los contenidos de la ley, no es interpretar los designios de Dios, es gestionar la actividad de los hombres a partir de los datos que nos otorga la observación de los propios hombres.

Gobernar es, entonces, una forma de poder centrada específicamente en la elaboración de los medios necesarios para encaminar a los hombres. En el siglo XVI, este sentido se vuelve más preciso. Foucault cita el texto Miroir Politique escrito en 1555 por La Perriére, quien afirmaba: “Gobierno es la recta disposición de las cosas, de las cuales es menester

\footnotetext{
123 (Cfr, STP, 148ss).

${ }^{124}$ Foucault muestra cómo incluso cuando se hable de gobernar la ciudad, el sentido que esta formulación tiene no es el de dirigir la ciudad como estructura política, sino el de organizar los medios para que la gente pueda vivir en una ciudad (STP, 18-149).
} 
hacerse cargo para conducirlas hasta el fin oportuno" (STP, 121). El francés se detiene cuidadosamente en esta definición para mostrar que el término gobernar utilizado en este contexto, tiene un sentido bastante específico ${ }^{125}$ : no se trata de legislar, reinar, dominar ni oprimir. Gobernar es conducir las cosas -y por ellas La Perriére no entendía los objetos en sí mismos, sino todas las relaciones que involucran a los hombres que se quieren gobernargestionarlas, organizarlas para llevarlas a un fin específico de acuerdo a su propia disposición.

Así, la primera característica que el francés retoma del concepto de gobierno en el siglo XVI es que tanto el objeto de su acción, como la definición de sus procedimientos, dependen únicamente de los resultados obtenidos de la observación del hombre. No se gobierna en función de las leyes, aunque estas pueden utilizarse para cumplir mejor el objetivo deseado; no se gobierna en función de la palabra de Dios, aunque esta pueda servir para justificar tanto el fin como los medios del gobierno; no se gobierna en función de un territorio, aunque su posesión pueda ser indispensable. Se gobierna de acuerdo a lo que indican los datos obtenidos a través de la observación del comportamiento de los hombres. Además de este primer elemento, Foucault acentúa dos cosas más: la primera es la pluralidad de las formas de gobierno existente en el siglo XVI, y la segunda es la relación intrínseca entre gobierno y verdad. Analicemos ambas características.

Cuando en los siglos XV y XVI se hablaba de gobierno, no se aludía necesariamente a un gobierno político. El "arte de gobernar" tenía diversos objetivos. Se hablaba de "arte de

\footnotetext{
${ }^{125}$ El problema del gobierno es esencial para Foucault. Entre otras cosas genera una redefinición de su idea de poder que nos permite alejarnos de críticos como Habermas o Honneth, para quienes el poder en Foucault se identifica con la idea de lucha de fuerzas, opresión o dominación.
} 
gobernar" para la dirección de uno mismo, para la dirección de los niños, las almas o la familia ${ }^{126}$. Foucault señala que entre los siglos XVI y XVIII hubo un "florecimiento",127 de tratados sobre el "arte de gobernar". Estos tratados no sólo indagaban la mejor forma de conducir políticamente una nación, también tematizaban otros asuntos: ¿cómo gobernarse a uno mismo (reactivación de los estoicos en el siglo XVI)?, ¿cómo gobernar a los niños (problema de una pedagogía emergente)?, ¿cómo gobernar las almas (problema del pastorado)?, ¿cómo gobernar un Estado?, etc. ${ }^{128}$ A Foucault le interesa resaltar esto por una razón a la vez histórica y conceptual: la noción de gobierno no era exclusiva de las grandes instituciones políticas, la actividad de gobernar no era responsabilidad exclusiva del monarca o el Papa, era, por el contrario, una forma de poder que tenía múltiples niveles y que definía sus fines y sus procedimientos dependiendo del ámbito de realidad al que se dirigiera. No usaba las mismas técnicas ni los mismos procedimientos quien intentaba gobernar a los niños, que quien gobernaba las almas de sus ovejas o quien dirigía a su familia.

A partir de estas constataciones históricas, Foucault retoma la noción de gobierno; pero ahora no sólo como objeto de análisis histórico, sino como instrumento teórico. Entre otras cosas, acuñar el concepto de gobierno le permite rehuir de cualquier noción que pudiera obligarlo a circunscribir su analítica del poder a una sola esfera de la realidad, ya sea la económica, la jurídica o la política. Así, el segundo elemento que el francés retoma de la noción de gobierno tal y como aparece en el siglo XVI es su pluralidad. El gobierno puede tomar múltiples formas y adecuarse a múltiples objetivos, ya sea la productividad, la

\footnotetext{
126 (Cfr, SP, 1056).

127 (Cfr, STP, 110).

128 (Cfr, STP, 107-139).
} 
salvación eterna, la salud, etc.

Por último, analicemos el tercer elemento. Si como hemos dicho, gobernar implica una forma de conducir a los hombres en función de las disposiciones que a ellos corresponden y no de otras, nos damos cuenta inmediatamente de que el problema del gobierno nos enfrenta al de la verdad. En efecto, si se conduce a los hombres en la dirección que se les conduce, si se disponen así, si se recomiendan ciertas tácticas y procedimientos y no otros, es sólo porque se conoce la verdadera disposición de los hombres que se gobiernan, es sólo porque se posee un saber de ellos que legitima el tipo específico de práctica con la que se les dirige. Las tácticas y los procedimientos utilizados para gobernar se generan en función del conocimiento que se tiene de los hombres en un contexto y en un ámbito de realidad específicos. Gobernar, entonces, es poner en contacto cierta “economía”, cierta gestión sobre los hombres, cierta dirección de las conductas, con un tipo de discurso que pretende ser verdadero; gobernar es administrar estratégicamente un complejo de relaciones a partir de ciertas prácticas que se vinculan con un conocimiento justificatorio. Gobernar es, en suma, una práctica de poder que depende de formas de saber. Entender el poder en términos de gobierno, es entender que el poder no sólo no excluye al saber, sino que depende de él, funciona gracias a él, se construye en el mismo terreno que él y lo atraviesa en todo momento; es entender, también, que ciertos saberes específicos se constituyen en la misma red que el poder y no por ello lo falsifican.

Estos tres elementos nos permiten llenar de contenido el concepto foucaultiano de gobierno. Habíamos dicho que a finales de los setentas Foucault terminó de separarse de la hipótesis Nietzsche y refundó su aparato conceptual a partir de la noción de gobierno. 
Ahora que sabemos con exactitud a qué se refiere con este concepto, podemos comprender mejor en qué consistió el ajuste teórico efectuado en esos años. Ante las constantes acusaciones de promover una noción de poder irracional y violenta, Foucault se valió de un concepto que no sólo retomaba lo mejor de sus intuiciones anteriores, sino que les daba una sólida consistencia teórica. Una analítica de poder entendido como gobierno, es un proyecto filosófico que analiza la manera en que se han constituido técnicas y procedimientos para dirigir la conducta de los hombres, asumiendo que esas técnicas y esos procedimientos se apoyan en saberes que ostentan pretensiones de verdad; es asumir, también, que tanto el contenido de esas prácticas como el de sus saberes correlativos dependen del ámbito específico de realidad en el que operan. Por lo mismo, estudiar la forma en que se ha gobernado a los hombres requiere una indagación histórica incesante, pues el contenido de las formas de gobierno y de los saberes específicos que a ellas se vinculan no preexiste a ninguna práctica de poder concreta, sino que adquiere sus determinaciones singulares en la historia y en la red de relaciones que la enmarcan. Así, queda claro que el proyecto foucaultiano de analizar las relaciones de poder no implica una concepción unilateral de la realidad en la que se erija la fuerza y la lucha sobre todas las actividades humanas; queda claro también, que Foucault no cree que el poder sea un impulso violento e irracional que determine la realidad social independientemente de la individualidad humana. El poder nunca puede definirse al exterior del proceso específico de su determinación histórica concreta. Con el término de gobierno, el francés deja claro que su intención es analizar aquellos procedimientos que, en la evolución efectiva de las sociedades y debido a la actividad racional de los hombres, configuran relaciones en las que la conducta de ciertos sujetos es estructurada y dirigida hacia un fin a través de una serie compleja de técnicas, las cuales no siempre obedecen a la lógica de la coerción, la prohibición o la limitación, sino 
que también pueden operar mediante la producción de saberes, la puesta en marcha de series discursivas, la construcción de espacios, o la generación de verdades. Todavía más, Foucault cree que esas prácticas producen realidad y producen sujetos; es decir, estas prácticas no se vienen a hipostasiar a la estructura de un sujeto ya existente, el sujeto es el resultado de su interacción con esas prácticas. En ese sentido una analítica de gobierno es también y, sobre todo, un análisis de las formas de construcción de la subjetividad humana.

Este punto es esencial. Frederic Gros ${ }^{129}$ señala adecuadamente que la principal diferencia entre la noción de poder foucaultiana aun adscrita a la "hipótesis Nietzsche", y los conceptos de gobierno y gubernamentalidad, consiste en que, mientras la perspectiva bélica le atribuía un papel pasivo a los sujetos y un carácter subordinado a los saberes, la noción de gobierno permite asumir a los sujetos como agentes activos que se enfrentan a ciertas formas de gobierno, además de que le concede a los conocimientos y saberes una dignidad propia. Al entender la noción de poder en términos bélicos, daba la impresión que el saber y el sujeto eran únicamente producciones del poder, sin autonomía propia. De ahí que una y otra vez, el francés fuera caracterizado como un autor determinista. El concepto de gobierno y, con mayor claridad, el de gubernamentalidad, permiten superar este impasse generando una rejilla de análisis capaz de incorporar la libertad del sujeto y la autonomía del saber científico en un esquema que, sin embargo, no es ajeno al poder. Para poder entender este movimiento, debemos analizar a detalle la noción de gubernamentalidad.

\subsection{1.- Gubernamentalidad y resistencia}

${ }^{129}$ (Cfr, Gros, 2007,111) 
Ahora bien, si el concepto de gobierno es importante para el francés, el concepto de "gubernamentalidad" posee igual o mayor relevancia. Jean Terrel señala adecuadamente que la noción de "gubernamentalidad" completa la noción de gobierno ${ }^{130}$ en varios sentidos. El término "gubernamentalidad" se refiere a las formas de racionalidad (rationalité) por medio de las cuales se organizan las técnicas de gobierno (gouvernement) ${ }^{131}$. Años atrás, el autor de Vigilar y castigar utilizaba el término "tecnologías de poder" para dejar asentado que el poder circula a través de técnicas (tekné) que se articulan racionalmente (lógos) con formas de saber que le dan sentido y dirección. Con el concepto de "gubernamentalidad", en cambio, pretende analizar, no ya las técnicas por medio de las cuales opera el poder, sino la racionalidad subyacente a la conducción de los hombres. Lo que el francés llama "gubernamentalidad" es, pues, el resultado del trabajo reflexivo que intenta darle orden y dirección a las formas de gobierno. Para decirlo con otras palabras, las prácticas de gobierno no emergen de la nada, no son meras ocurrencias de hombres insensatos, son el resultado de un proceso racional que, reactualizándose una y otra vez, impone fines, objetivos y estrategias de acción sobre los sujetos para dirigir sus conductas; el concepto de "gubernamentalidad" permite, justamente, dar cuenta de ese proceso. Colin Gordon lo expresa con exactitud: "A rationality of governments will thus mean a way or system of thinking about the nature of the practice of government (who can govern; what governing is; what or who is governed), capable of making some form of that activity thinkable and practicable both to its practicioners and to those upon whom it was practiced" (Burchell, 1991, 3).

\footnotetext{
${ }^{130}$ (Cfr, Terrel, 2010, 9).

131 (Cfr, STP, 136ss) y (Senellart, Michel, "Situación del curso", en: STP, 447ss).
} 
Si con la noción de gobierno Foucault intenta analizar las prácticas de conducción de los sujetos, con la noción de "gubernamentalidad" explora, como afirma Jean Terrel, la forma en que éstas fueron racionalizadas: "Las practiques gouvernementales sont sans cesse anticipées et prolongées par un travail de pensé qui les prépare, les évalue et les infléchit: la «gouvernamentalité» est donc d'abord une expérience critiquée et réfléchie, ou l'ensemble formé par las techniques et l'art de les reflechir et de les rationaliser" (Terrel, 2010, 9). Así, un análisis de las formas de "gubernamentalidad", debe entenderse como un estudio de la racionalidad inmanente que hace operar en una dirección, hacia unos objetivos y a partir de ciertas formas de saber, las conductas de los sujetos, aun cuando en los hechos los objetivos designados nunca se cumplan con exactitud. Evidentemente, la racionalidad inmanente a la conducción de ciertos actores sociales no es consustancial a la naturaleza humana, ni depende de la voluntad de un sujeto privilegiado; por lo mismo, no puede ser explicada a partir de perspectivas que analicen la conciencia humana, o explorando los recónditos intersticios de su psique, y, mucho menos, realizando una clasificación de sus facultades básicas, como si el hombre fuera un universal invariable ${ }^{132}$; la "gubernamentalidad", por el contrario, debe ser analizada a partir de las "prácticas"133 que hace funcionar; es decir, en las serie de acciones -discursivas y no discursivas- insertas en regularidades indagables materialmente que producen efectos en la conducta de los hombres. Más que partir de universales antropológicos y deducir de ellos los requisitos que exige una conformación social ideal ${ }^{134}$, más que generar modelos de sociedad

\footnotetext{
${ }^{132}$ Por ejemplo, en el texto titulado "Foucault", el autor dice "adoptar como hilo conductor de todos éstos análisis la cuestión de las relaciones entre sujeto y verdad implica ciertas lecciones de método. Y ante todo un escepticismo sistemático ante los universales antropológicos, [...]" (MF, 1001).

133 "De esto se sigue un tercer principio de método: el de dirigirse como dominio de análisis a las prácticas, y abordar el estudio por el sesgo de lo que se hace.” (MF, 1002).

${ }^{134}$ Ésta es la postura que Foucault le critica a Noam Chomsky en el famoso debate que sostuvieron en 1971 (Cfr, OE, 393ss).
} 
racionalmente justificables, Foucault utiliza el concepto de "gubernamentalidad" para estudiar la racionalidad que hace funcionar en determinada dirección, ciertas prácticas de gobierno. Como estas prácticas no son estáticas y se redefinen en todo momento, una "analítica" de los procesos de "gubernamentalidad" requiere un acercamiento, a la vez, histórico, "ontológico"135 y "epistemológico"136, pues es en el desarrollo de esas prácticas que la realidad adquiere consistencia, que los campos discursivos emergen y los regímenes de verdad se constituyen ${ }^{137}$. Para Foucault "Ser" y "Verdad" son producto de un desarrollo histórico incesante que crea la realidad al mismo tiempo que genera sus criterios de valoración; Foucault no se cansa de señalar que esos criterios y esa realidad no se encuentran al margen de formas de gobierno específicas, sino que surgen en contacto directo con ellas, sin que ello implique que el gobierno anule la verdad o la verdad anule el gobierno.

En buena medida, la noción de "gubernamentalidad" le da claridad al pensador francés para abordar un tema que, si bien había sido recurrente en su trabajo, se prestaba a muchas confusiones; a saber, la relación entre poder y verdad. Un análisis de la "gubernamentalidad" es un estudio que pretende dar cuenta de la conformación de ciertas formas de racionalidad que incorporan, producen y reproducen, discursos con pretensiones de verdad en su intento de dirigir, de una u otra manera, las conductas de ciertos sujetos. Definida así, la categoría de “gubernamentalidad” nos permite dejar atrás las posibles confusiones de una noción de poder que, para algunos, lindaba con los terrenos de la violencia y la irracionalidad. Si con la noción de "gubernamentalidad” Foucault analiza las

\footnotetext{
${ }^{135}$ (Cfr, QI, 988).

${ }^{136}$ Para un análisis de las implicaciones de una epistemología histórica puede consultarse el capítulo titulado "Sobre epistemología y arqueología: de Canguillem a Foucault", en: (Davidson, 2005, 281ss) y el artículo titulado "Arqueología, genealogía, ética" del mismo autor en: (Couzens Hoy, David (comp.), 243ss). ${ }^{137}$ (Cfr, AS, 33ss).
} 
construcción de formas de racionalidad que incorporan, producen y reproducen formas de conocimiento para dirigir a los sujetos, es claro que ni el poder es irracional, ni la verdad es ajena a las formas de gobierno; pero, sobre todo, que la verdad no es, necesariamente, un epifenómeno del poder, sino que los hombres en su intento de dirigir la conducta de los otros se valen de ciertas formas de saber ya existentes, reproducen otras, recrean algunas y modifican ciertos criterios epistémicos para adaptarlos a su realidad y a sus necesidades. Una analítica de la "gubernamentalidad" debe ponderar en qué ocasiones sucede una cosa y en cuales otra. Dicha analítica no puede definir de antemano que el poder subordina todas las formas de saber de manera absoluta, pero sí señalar que, al analizar los métodos con que se conduce a los hombres, es necesario tomar en cuenta los saberes y las múltiples formas en que éstos se relacionan con los distintos modos de gobierno.

Fréderic Gros señala con claridad que las nociones de gobierno y gubernamentalidad permiten que Foucault le de un estatuto activo tanto a los saberes, como a los sujetos, ya que la noción de poder usada hasta mediados de los 70's, hacía pensar que todos los demás ámbitos de la realidad estaban subordinados a ella:

En el fondo, la noción de poder, según la pensaba Foucault en la primera mitad de los años setenta, abarcaba saberes y subjetividades en tanto puntos de inscripción pasivos. Hacer una genealogía era mostrar de qué modo relaciones de poder históricamente determinadas actuaban como matrices de formas de saberes y de formas de subjetividades. Por ejemplo, el poder disciplinario produce individuos (en tanto sujetos constituidos en relación con la norma), y se vale de las ciencias humanas como ritual de verdad.

Por el contrario, la problemática de la gubernamentalidad instalará la idea de una articulación entre formas de saber, relaciones de poder y procesos de subjetivación, que son 
planos distintos. Se establece un gobierno sobre sujetos y con la ayuda de saberes. (Gros, 2007, 111).

El saber es, pues, un elemento que se articula en procesos de gubernamentalidad. Una analítica de las formas de gubernamentalidad debe indagar el cómo y el por qué de esa articulación, así como sus efectos en los regímenes de verdad y en los procesos de gobierno sobre los sujetos. Se ve con claridad que esta tesis es más compleja que la sencilla afirmación de corte nietzsceano que reza de la siguiente manera: la verdad siempre es el resultado de las luchas de poder. Que se entienda bien, desde luego que la verdad se inscribe y se debate en luchas de poder, pero ella no es sólo una manifestación de éste. El conocimiento puede ser usado para gobernar, puede ser propiciado en un mecanismo gubernamental, puede ser utilizado para justificar acciones, etc.; a su vez, formas de gobierno pueden apoyarse en saberes legítimos previamente existentes para funcionar, pueden generar los propios, pueden reproducir rituales de verdad y justificar los criterios evaluativos de sus análisis en relación a ciertas intenciones gubernamentales. Gracias al concepto de "gubernamentalidad", Foucault pude crear un marco analítico capaz de reconocer que el papel del saber es mucho más complejo que aquél que le atribuía Nietzsche. En esencia, la noción de "gubernamentalidad" permite dos movimientos teóricos esenciales: por un lado, sostiene la idea de que la verdad y los saberes no son ajenos a las relaciones de asimetría, sujeción y conducción pero, por el otro, no cae en aquella homologación abstracta que elimina toda diferenciación entre formas de conocimiento afirmando que el saber, hágase lo que se haga, siempre es una excrencia del poder y sólo una excrecencia del poder. 
El otro tema esencial que Foucault transforma con la noción de "gubernmentalidad" es el del sujeto. Arriba señalamos que el tipo de racionalidad que incorpora formas de saber para conducir a los sujetos funciona en la medida en que estructura el campo de posibilidades de sus acciones. Es decir, la "gubernamentalidad" nos permite estudiar cómo se ha intentado racionalizar la dirección de las conductas de los hombres y cómo se han incorporado y generado saberes en este intento; sin embargo, esto no quiere decir que, en los hechos, los hombres hayan obedecido plenamente esas directrices, tampoco quiere decir que en su actuar y en la constitución de su subjetividad no hayan intentado, ellos también, gobernarse a sí mismos y resistirse al gobierno de los otros. La noción de gobierno y la noción de gubernamentalidad, nos reenvían de forma inmediata al problema de la libertad y la resistencia. Veamos.

En el apartado anterior señalamos una y otra vez que gobernar era un actividad muy específica, no consiste ni en esclavizar, ni en dominar, ni en regir, sino en estructurar el campo de posibilidades de los sujetos para dirigir sus acciones hacia un fin. Foucault cree que esta definición le permite superar aquellas críticas que le reprochaban haber generado un concepto de poder determinista, el cual eliminaba todo margen de acción de los sujetos. Para Foucault, el concepto de gobierno supone, necesariamente, el de libertad. Si se intenta estructurar el campo de acción de los sujetos, si se pretende dirigirlos, si se quiere establecer un marco para circunscribir sus elecciones, es sólo porque, de hecho, ellos toman decisiones, establecen formas de acción y le dan una dirección a su comportamiento. Si los sujetos no tuvieran un rango de acción libre, ni siquiera sería necesario intentar modificar su comportamiento, de nada servirían todos esos mecanismos, esas tácticas y esas estrategias, simplemente se los doblegaría con una orden. Es porque, de hecho, los sujetos 
son libres, que se requiere apelar a ciertos saberes, establecer ciertas tácticas, incorporar ciertos dispositivos, para modificar su conducta.

En "El sujeto y el poder", Foucault deja claro que las relaciones de gobierno no deben confundirse con las relaciones de violencia ${ }^{138}$. Esta aclaración es sumamente importante, ya que nos permite ver la relación entre poder y libertad. Cuando se habla de gobernar a alguien, se asume que éste posee un margen de acción para resistirse y oponerse; en cambio, cuando se habla de violencia se asume que existe una coerción capaz de restringir la autonomía de los sujetos de manera absoluta durante un periodo de tiempo considerable. No cabe duda de que ciertas formas de gobierno pueden volverse actos de violencia, pero identificar gobierno y violencia resulta erróneo pues, al hacerlo, se soslaya que existen formas de conducir las acciones ajenas que no se sostienen en el uso de la fuerza.

De la misma manera que el gobierno no se contrapone al conocimiento, tampoco se contrapone de forma absoluta a la libertad. Foucault no concibe esta última como un dato universal o como un supuesto que hace funcionar nuestro lenguaje moral, sino como una construcción permanente que adquiere sus determinaciones en estrecho vínculo con las formas en que históricamente se ha intentado delimitar las posibilidades de acción de los sujetos. De ahí que la libertad no sea lo absolutamente otro del poder, sino su contracara:

\footnotetext{
138 "[Le Pouvoir] n'est pas en lui-même une violence qui saurait parfois se cacher, ou un consentment qui, implicitement, se reconduirait. Il est un ensemble d'actions sur des actions posibles: Il opère sur le champ de possibilité où vient s'inscrire le comportement de sujets agissants:il incite, il induit, il détourne, il facilite ou rend plus difficile, il élargit ou il limite, il rend plus o moins probable; à la limite il contraint ou empêche absolutment; mais il est bien toujours une manière d'agir sur un ou sur des sujets agissants $[\ldots]$ Le mode de relation propre au pouvoir ne serait donc pas à chercher du côté de la violence et de la lutte, ni du côté du contrat et du lien volontaire (qui ne peuvent en être tout au plus que des instruments): mais du côte de ce mode d'action singulier -ni guerrerier ni juridique qui est le gouvernement"(SP, 1055-1056).
} 
Quand on définit l'exercise du pouvoir comme une mode d'action sur les actions des autres, quand on les caractérise par le gouvernement des hommes les uns par les autres -au sens le plus éntendu de ce mot-, on y inclut un élément important: celui de la liberté. Le pouvoir ne s'exerce que sur des sujets libres, et en tant qu'ils sont libres -entendons par là des sujets individuels ou collectifs qui ont devant eux un champ de possibilité où plusieurs conduites, plusieurs,réactions et divers modes de comportement peuvent prendre place. Là où les déterminations sont saturées, il n' y a pas de relation de pouvoir[...]Il n'y a donc pas un face-à-face de pouvoir et de liberté, avec entré eux un rapport d'exclusión (partout où le pouvoir s'exerce, la liberté disparait); mais un jeu beaucoup plus complexe: dans ce jeu la liberté va bien apparaître comme condition déxistence du pouvoir (SP,1056-1057).

Para Foucault, el sujeto se construye como tal en una relación ambivalente, depende, a la vez, de ciertas condiciones externas que le imponen determinadas formas de acción posible y de la producción de sí mismo que, a pesar de esas condiciones, logra llevar a cabo ${ }^{139}$. Ahora bien, dado que las relaciones de poder se transforman constantemente, las formas en que el sujeto se dota de un espacio de libertad también adquieren distintas determinaciones. Dentro de la filosofía del francés, la libertad no puede ser pensada únicamente como una condición de posibilidad, debe ser entendida también como una elaboración histórica. Para Foucault, el término libertad es una formulación meramente abstracta si se le desarraiga de su historicidad efectiva, su contenido concreto depende de la correlación existente en un momento dado entre ciertas formas de sujeción y ciertas formas de resistencia. Por ello, en el curso de 1979 afirma:

La libertad no es una superficie en blanco que tenga aquí y allá y de tanto en tanto casillas más o menos numerosas. La libertad nunca es otra cosa -pero ya es mucho-que una relación actual entre gobernantes y gobernados, una relación en que la medida de la "demasiado poca" libertad existente es dada por la "aún más libertad que se demanda"( NB,.83).

\footnotetext{
${ }^{139}$ Respecto a este tema el trabajo de Judith Butler resulta sobresaliente, ya que ha intentado amalgamar la perspectiva foucaultiana del poder con una teoría del sujeto de corte psicoanalítico ( $C f r$, Butler, 2001).
} 
Nos encontramos ante un juego que no puede ser concebido bajo la lógica del todo o nada: o mero dominio o mera liberación. A diferencia de aquellas filosofías que hacen una partición tajante entre libertad y dominación ${ }^{140}$, Foucault cree que la libertad nunca se presenta al margen de relaciones de gobierno. Es más, es al interior de esas relaciones que se construye y determina. A diferencia de lo que podría deducirse desde una lectura superficial, Foucault se toma en serio el espíritu que impulsó y revolucionó la filosofía en la modernidad; a saber, la búsqueda de la absoluta autonomía del hombre en el mundo. Sin embargo, sabe que esa autonomía no se obtiene solamente proclamando teóricamente nuestra liberación de toda tutela exterior, sino indagando las formas específicas en que se ha sujetado al hombre. Al mostrar los procesos específicos de gobierno, el francés intenta evidenciar, por contraste, nuestras posibles vías de liberación ${ }^{141}$. Por lo mismo, su filosofía no intenta generar conceptos teóricos purificados -cosa loable e incluso necesaria-, sino mostrar las relaciones históricas específicas entre formas de sujeción, procesos de veridicción y relaciones de poder, con la intención de abrir un espacio reflexivo para pensar las formas de liberación plausibles en un momento dado y en una circunstancia histórica específica.

Por último, si el concepto de gobierno nos permite pensar las relaciones de poder y la libertad como dos caras de una misma moneda, el concepto de "gubernamentalidad", por su

\footnotetext{
${ }^{140}$ La división entre poder y violencia realizada por Hannah Arendt es, sin duda, un ejemplo claro de esta perspectiva binaria (Cfr, Arendt,2006).

${ }^{141}$ Dice Foucault: "Je voudrais suggérer ici une autre manière d'avancer vers une nouvelle économie des relations de pouvoir, qui soit à la fois plus empirique, plus directement reliée à notre situation presente, et qui implique davantage de rapports entre la théorie et la pratique. Ce nouveau mode d'investigation consiste à prendre les formes de resistence $[\ldots]$ comme une catalyseur chimique qui permet de mettre en évidence les relations de pouvoir"'(SP,1044).
} 
parte, nos reenvía al problema de la resistencia. Si una forma de "gubernamentalidad" articula relaciones de saber y técnicas de poder para conducir a los hombres hacia cierta finalidad, es posible oponer otras formas de conocimiento y otros objetivos para resistirnos a ella. No sólo eso, también es posible utilizar los mismos saberes que en un momento dado se destinan a una forma de gobierno, para darles otra dirección. La noción de "gubernamentalidad", nos permite salir del embrollo en el que nos metía la hipótesis Nietzsche. En efecto, si el poder es concebido como una lucha de fuerzas perpetua, resulta difícil pensar cómo salir de él; de una u otra manera siempre que nos opusiéramos a una forma de poder estaríamos imponiendo otra. Pero si se problematizan las relaciones de poder desde las formas de "gubernamentalidad", es posible indagar la racionalidad intrínseca a ciertas formas de conducción de los otros verificando qué saberes y qué técnicas la sostienen. Al hacer esto, se puede atacar una forma de "gubernamentalidad" específica de múltiples maneras, ya sea mostrando la inconsistencia de los saberes que la sostienen, ya sea mostrando la finalidad que persiguen, ya sea evidenciando el tipo de sujeto que pretende modelar, etc. Así, la analítica de las formas de "gubernamentalidad" se vuelve, inmediatamente, un campo de estudio de las posibles formas de resistencia, de los puntos endebles de ciertas formas de gobierno y de las probables fracturas que pueden provocarse en ellas. Al respecto dice Frederic Gros:

Las formas de saber y de relación consigo mismo serán pensadas cada vez más, antes que como simples pseudópodos del poder, como puntos de articulación de procesos de gubernamentalidad. Lo cual significa que formas dadas de subjetividad o de saberes determinados podrán operar como resistencias a ciertos procesos de gubernamentalidad. Demasiado compacta, la noción de poder impedía pensar la resistencia: esta nunca era otra cosa que una modalidad de cierta relación de fuerzas. La idea de resistencia al poder encerraba entonces un contrasentido: no hay resistencia más que en el poder, pero nada es tan exterior al poder que pueda oponerse a él. En cambio, se puede resistir a formas de 
gobierno. Es posible negarse a ser gobernado de tal modo o de tal otro, y oponer a formas de saber o de subjetividad articuladas con ciertos procedimientos de gobierno, otros discursos teóricos o maneras de relacionarse consigo mismo. Y es a partir de esta nueva noción de gobierno que Foucault podrá pensar su propio trabajo como introducción de puntos de resistencia (Gros, 2007,111-112).

Vale la pena agregar una cosa, la noción de resistencia es absolutamente precisa en este contexto. No se trata de reivindicar un modelo ideal de sociedad al cual aspiraríamos en condiciones enteramente racionales, ni de suponer un estado de absoluta autonomía y libertad previo a todo orden político, tampoco de imaginar cómo sería el humano verdadero si no estuviera sujeto a ninguna relación de dominación; por el contrario, se trata de captar la trama de relaciones sociales específicas en las que, en una sociedad dada, se dirige a los hombres; esto con la intención de realizar un diagnóstico concreto de los modos en que ellos pueden oponerse a esas relaciones. En el fondo, la noción de resistencia, no sólo implica una concepción de la libertad absolutamente realista, sino también absolutamente positiva. Se es libre porque, en un mundo en el que inevitablemente nos enfrentamos con la existencia de otros, los hombres tienen la capacidad de oponerse a las relaciones que los condicionan. De tal suerte que, para nuestro autor, la libertad no es un artificio de la voluntad humana, tampoco un supuesto a- temporal y transhistórico, sino el resultado de las confrontaciones específicas que, en un momento y en un lugar, determinan la vida de los sujetos. Foucault entiende la libertad como la capacidad de resistirse a la imposición de lo externo; sin embargo, esa resistencia no supone un estado puro en el que no habría ninguna mediación ajena, sino que es, ella misma, resultado de las influencias que una y otra vez los 
sujetos y el mundo ejercen sobre nuestras elecciones ${ }^{142}$.

\section{III.- Distinción entre los conceptos de racionalidad en Habermas y Foucault.}

\section{( A modo de conclusión: balance general de la crítica foucaultiana frente al modelo}

\section{normativista)}

En el fondo, la crítica que recorre todo El discurso filosófico de la modernidad puede

resumirse en los siguientes términos: de Hegel a Foucault los intentos de salir de una

filosofía de la conciencia han derivado en posturas problemáticas porque, al ser incapaces

de hallar los medios para fundamentar una normatividad fuerte, deshabilitan su propia

actividad crítica y coquetean con el relativismo. En el texto mencionado, Habermas

\footnotetext{
${ }^{142}$ De nuevo, Foucault se asemeja a al noción de libertad que Hegel propone en la Filosofía del Derecho. En los primeros parágrafos de la Filosofia del derecho (Hegel,1993) se analizan los tres momentos en que la voluntad intenta objetivarse en el mundo; en el primero, la voluntad se presenta como un querer inmediato sin determinación, quiere todo indiferentemente: se encuentra transida de un deseo infinito; pero por su propia abstracción esta voluntad es incapaz de objetivarse, debe poder querer algo determinado para realizarse. En un segundo momento la voluntad niega la abstracción del primer momento determinándose en "algo", al hacerlo renuncia a todas las posibilidades que no elige, pero esta negatividad manifiesta un paso hacia la libertad, pues la voluntad es libre de elegir lo que quiere contradiciendo incluso sus propios apetitos. Sin embargo, esta libertad es aún insuficiente, si bien ya se determina en un objeto, ese objeto se le presenta como algo dado. Todavía no es libre de "elegir lo que elige". La insuficiencia de la libertad se manifiesta aquí porque sigue dependiendo de un factor externo, no ya dentro de su subjetividad, sino en la objetividad de lo elegido. Sólo en el tercer momento la voluntad libre no sólo puede elegir, sino que es capaz de darse a sí misma el contenido de lo que elige ( $C f r$., Vieweg,2009,15-35). Sergio Pérez señala lo siguiente respecto al tercer momento: "[...] la voluntad verdaderamente libre;[ésta] lo es en un doble sentido: primero porque se ha abstraído de la contingencia de sus impulsos y sus tendencias primarias y actúa bajo el dominio del pensamiento y la razón. Luego porque la superación de esa inmediatez no la conduce a otra forma de contingencia, esta vez exterior, sino a transformar ese exterior en una universalidad establecida por ella misma. De este modo, es actividad del pensamiento ejerciéndose en la voluntad, es inteligencia pensante, voluntad racional: se ha hecho libre no sólo en sí, es decir respecto a sus tendencias, sino también para sí, en su exterioridad"(Rendón,2007,97). Precisamente el momento del espíritu objetivo analiza la manera en que la voluntad se da el contenido de su propio querer en la objetividad del mundo o, para decirlo de otro modo, cómo se da la normatividad que regula su mundo de manera absolutamente libre. A nuestro entender, Hegel establece en tres momentos una relación dialéctica entre subjetividad y objetividad. Se parte de un momento unilateral en el que se cree que la libertad depende de la mera subjetividad, hasta llegar a la absorción de lo externo en lo interno; es decir, a la asunción de que la libertad es el resultado de una relación dialéctica en la que el sujeto debe conquistar su libertad en confrontación con una realidad objetiva que establece limites. A pesar de la mediación de lo objetivo, el sujeto nunca queda supeditado e inmóvil, sino que puede poner su voluntad en el mundo tratando de imponer sus fines conociendo los límites que la realidad le impone.
} 
pretende mostrar que tanto el joven Hegel, como Marx, Heidegger, Derrida y Foucault tuvieron la oportunidad de elegir opciones que hubieran encaminado su trabajo por el camino correcto y no lo hicieron:

[...] he subrayado los puntos en los que el joven Hegel, el joven Marx, todavía el Heidegger se Ser y tiempo y Derrida en su discusión con Husserl, se vieron ante opciones que no eligieron.

En Hegel y Marx la alternativa hubiera consistido en no tratar de reducir aquella intuici'ón de totalidad ética al horizonte de la relación que guarda consigo mismo el sujeto que conoce y actúa, sino en haberla explicado conforme al modelo de una formación no coactiva de una voluntad común en una comunidad de comunicación sujeta a la comunidad de cooperación. En Heidegger y Derrida la alternativa hubiera consistido en no atribuir los horizontes creadores de sentido en que nos viene interpretado el mundo a un Dasein que se proyecta a sí mismo en términos heroicos, o a un acontecer de la verdad, formador de estructuras, que se producen a espaldas de los sujetos, sino a los mundos de la vida comunicativamente estructurados que se reproducen a través del medio, bien accesible, que es la acción orientada al entendimiento (Habermas, 2010, p. 32).

Habermas piensa que, en su intento de salir de las filosofías de la conciencia, Foucault queda atrapado en un concepto de poder totalmente ambiguo. En vez de remitir a una "formación no coactiva de una voluntad común en una comunidad comunicativa", explica la actividad social echando mano de una noción totalizadora que "opera a espaldas de los sujetos". Para Habermas, la noción de poder foucaultiano posee una doble función: es, a la vez, dato empírico y estructura general de la historia. La aparente "objetividad" cuasi positivista que busca el autor de La arqueología del saber termina convirtiéndose, según Habermas, en un subjetivismo arbitrario, ya que de ninguna manera se logra justificar la decisión fundamental que recorre su "Teoría"; a saber, interpretar el desarrollo de la 
modernidad en la clave unilateral de la dominación. En este sentido, Habermas cree que el francés se vuelve a-crítico, pues no logra fundamentar el suelo desde el que pretende validar sus análisis y, al mismo tiempo, carece de los criterios normativos que le permitirían evaluar el presente. Por su parte, el pensador alemán no sólo está convencido de poder llevar a cabo una fundamentación normativa con pretensiones de universalidad, sino que hace depender de ello la posibilidad misma de una filosofía crítica. En un interesante artículo sobre Foucault titulado "What is Critique? An Essay on Foucault's Virtue" Judith Butler describe la postura de Habermas de la siguiente manera:

in his view, critical theory had to give way to a stronger normative theory, such as communicative action, in order to supply a foundation for critical theory, enabling strong normative judgments to be made, and for politics not only to have a clear aim and normative aspiration, but for us to be able to evaluate current practices in terms of their abilities to reach those goals ${ }^{143}$.

Por ello Habermas afirma que si sometemos a análisis la filosofía foucaultiana, ésta se nos revela, en el fondo, como una teoría profundamente a-crítica. De ahí, el tono que adquieren los más importantes críticos de la perspectiva genealogica. Aquellos que, en mayor o menor medida, defienden posiciones cercanas a la de Habermas creen, como Honneth, que un análisis genealógico sólo puede ser llamado crítico de forma "parasitaria"144, pues para ser verdaderamente crítico requiere adherirse a una normatividad racionalmente fundada. Para ellos, la verdadera limitación del proceder foucaultiano consiste en no poder darse un sustento teórico que le permita establecer parámetros de evaluación sobre nuestros juicios, nuestras acciones y nuestras perspectivas.

143

${ }^{144}$ (Cfr, Honneth,2009C) 
En este apartado intentaremos señalar las limitaciones de esta crítica. Desde la perspectiva de Habermas la insuficiencia teórica del proyecto de Foucault debe subsanarse poniendo "encima" de sus análisis una fundamentación normativa que nos aleje de todo posible relativismo. Haciendo uso de una metáfora espacial, nosotros sostendremos que la elección de no partir de una fundamentación normativa no lo coloca "debajo", sino "a un lado" de la perspectiva habermasiana. Es verdad que la filosofía foucaultiana no se dota de las herramientas conceptuales para realizar el arduo trabajo de fundar una normatividad universalista o con pretensiones de universalidad, pero la idea de que esta omisión se explica por un déficit teórico es falsa; igualmente falsa es la apresurada conclusión que ve en esta omisión un obstáculo determinante para las pretensiones críticas de su trabajo. En lo que sigue, quisiéramos sostener que la filosofía foucaultiana no se abstiene del trabajo de fundamentación de criterios por una necedad intransigente, sino porque tiene la intención de indagar la formación efectiva de los mismos y, por ello, no puede presuponerlos. En buena medida, una historia crítica del pensamiento destinada a analizar la cristalización de nuestra experiencia como sujetos hace de los criterios de verdad y de normatividad el dominio de su análisis. La pregunta de quiénes somos en tanto sujetos del presente implica investigar, también, la formación de nuestros criterios de verdad y del conjunto de objetos que, en un momento dado, son designados como elementos aptos para ser valorados por esos criterios; de la misma manera, implica el estudio del proceso de cristalización de los criterios de normatividad y del dominio de objetos que en un momento dado puede ser juzgado con base en los mismos. Esto, sin duda, implica que la concepción de racionalidad foucaultiana es distinta de la concepción de racionalidad habermasiana. Por más que el alemán intente anclar la razón en el mundo de la vida y no en una dimensión trascendental 
apelando a la pragmática formal del lenguaje y al proceso evolutivo que paulatinamente conformó nuestro sistema linguistico, creemos que, en última instancia, dicha concepción resulta insuficiente y aporética. Que se entienda bien. De nuevo, no queremos señalar que los descubrimientos de Habermas resultan erróneos o falaces, sino que son insuficientes al momento de hacer un diagnóstico del presente pues terminan circunscribiend a la razón en una serie de semi-trascendentales previos al movimiento efectivo de las prácticas concretas que, en el fondo, para el francés son las generadoras de criterios y de normas efectivas en el mundo.

Pero debemos explicar el verdadero sentido de esta precisión, de otra manera se nos podrá refutar diciéndonos acertadamente que los procesos de validez son independientes de los procesos de génesis y que, por lo mismo, la pretensión foucaultiana de cuestionar los criterios de verdad en su nivel histórico concreto deriva de la confusión entre ambos estratos. Cuando afirmamos que Foucault se pregunta por el proceso de formación de esos criterios, no ignoramos que, para cierta corriente filosófica, la fundamentación teórica de los mismos supone una dimensión contrafáctica irreductible a los procesos históricogenéticos. Para esta perspectiva, mostrar las relaciones de poder que afectan la normatividad real no incide para nada en su construcción teórico racional. Tampoco ignoramos que los elementos normativos que una postura de este tipo puede justificar tienen una función paralela a eso que Kant llamaba "ideas regulativas" y que, por lo mismo, pueden servir como parámetros críticos de nuestra historicidad efectiva. A nuestro entender, el asunto que está en juego en la práctica crítica del francés no ese deriva de su ignorancia respecto a esta división; más bien, debe remitirnos a los problemas internos de 
ese tipo de fundamentación cuando desea ir más allá de un formalismo que linda con la utopía.

Sin duda como heredero de la Escuela de Frankfurt, Habermas entiende bien lo insuficiente que puede llegar a ser una normatividad puramente a priori desvinculada de los procesos históricos efectivos. Por lo mismo, su filosofía realiza un enorme esfuerzopara hacer que la dimensión contrafáctica logre anclarse en la realidad. De entrada, la necesidad de remitirse a la pragmática formal tiene esta función, sin embargo en el sutil desarrollo de su fundamentación teórica se ve obligado a echar mano de la alusión a un contexto compartido para explicar los procesos de validez. Como se verá, aun en su dimensión contrafáctica, los criterios de normatividad dependen de la aceptación colectiva de un contexto compartido, esta aceptación contextual hace irremediable la pregunta por su conformación y nos invita a revisar qué tan desvinculada puede estar la validez de esos criterios de los proceso de su constitución real. Si, como ocurre en la argumentación de Habermas, el contexto debe asumirse en la propia mecánica de legitimidad, sostener la necesidad de una separación absoluta entre génesis y validez sólo es defendible si nos mantenemos en un nivel altamente formal y abstracto. Para poder explicar este punto y los problemas que le son inherentes reconstruiremos brevemente el planteamiento de Habermas y luego mostraremos en qué sentido decimos que la perspectiva foucaultiana se encuentra "a un lado" y no "debajo" de esa posición. Veamos.

3.1.- La racionalidad comunicativa como fundamento de la posición crítica en Habermas. 
En el importante artículo "Racionalidad de entendimiento. Aclaraciones al concepto de racionalidad comunicativa desde la teoría de los actos de habla" ${ }^{\text {"145 }}$ el autor de Verdad y justificación intenta responder las pertinentes críticas realizadas por Herbert Schnädelbach. En lo esencial este último le reprocha haber sobreestimado la importancia de "la racionalidad argumentativa o discursiva" en la formulación de su concepto de "racionalidad" pues, al hacerlo, corre el riesgo de ampliar el terreno de lo irracional a capacidades que, si bien no obedecen a una racionalidad argumentativa o discursiva, no pueden ser denominadas simple y llanamente irracionales. Según Schnäldelbach si el estatuto de racionalidad depende primordialmente de la discursividad o de la capacidad argumentativa, factores como el aprendizaje de los errores, el examinar la realidad, la elección teleológica de medios, etc. tendrían que ser valorados como participes de una racionalidad deficitaria o como actividades irracionales, cosa que evidentemente resulta bastante problemática ${ }^{146}$.

Con el fin de responder a esta crítica Habermas explica que las tres raíces de racionalidad que él analiza; a saber, el conocimiento -al que le es inherente una estructura proposicional, la acción -íntimamente relacionada a una estructura teleológica- y el habla -ligado a una estructura comunicativa-, no tienen un fundamento común en la estructura discursiva de la argumentación (la cual, como se puede sospechar, es un derivado de la estructura comunicativa del habla). Lo que esto quiere decir es que ni la racionalidad del conocimiento, ni la racionalidad de la acción están supeditadas a la racionalidad discursiva, o al menos no lo están en una relación de fundamento-fundado. El autor de Facticidad y validez piensa que la capacidad argumentativa no resulta preponderante porque funde o

\footnotetext{
${ }^{145}$ (Habermas, 2007, p. 99ss)

${ }^{146}$ (Habermas, 2007, pp. 99-101).
} 
subyazca a todas las formas de racionalidad, sin embargo sí posee cierta preeminencia debido a un motivo bien peculiar; a saber, su capacidad "integradora". Según el filósofo alemán la capacidad de argumentación inherente a nuestra capacidad racional resulta esencial porque sólo ella puede ensamblar las tres raíces antes mencionadas. Esto último merece una explicación, Habermas sostiene que nuestra posibilidad de manifestar y juzgar las pretensiones de validez de las tres raíces de racionalidad implica, necesariamente, su paso por el canal de la discursividad ${ }^{147}$, de tal manera que ésta unifica e integra tanto la forma de racionalidad dirigida al conocimiento, como la que se dirige a la acción teleológica y, por último, la que se vuelca a la acción comunicativa.

Expliquémonos mejor. Schnädelbach opone su propia posición a la supuesta centralización discursiva que Habermas realiza, para él la racionalidad debe definirse menos acudiendo a la capacidad de argumentación que considerando su "tener reflexivo": "aquello que sabemos, hacemos y decimos, es racional solamente si somos conscientes $^{148}$, al menos implícitamente, de por qué nuestras creencias son verdaderas, nuestras acciones correctas y nuestras expresiones lingüísticas válidas" (Habermas,2007,p.100). Pero el filósofo de Frankfurt refuta esta posición por dos razones. Su apego a una filosofía de la conciencia y su incomprensión de los alcances de la racionalidad discursiva. En primer lugar señala que Schnädelbach se mantiene en el paradigma de las "filosofías de la consciencia" pues sigue remitiendo a una relación auto-reflexiva en la que la consciencia del sujeto y sólo ella define la razonabilidad de los actos, las acciones y las expresiones lingüísticas. Por el otro lado, afirma que su remisión a la discursividad sostiene de forma más satisfactoria la

\footnotetext{
${ }^{147}$ Se podría refutar que cuando realizo una acción racional no necesariamente exteriorizo un discurso hacia una segunda persona; sin embargo Habermas apunta que siempre que quiera valorar la racionalidad de mi acción debo pasarla por el tamiz de la argumentación aunque sea mediante un discurso interno

${ }^{148}$ Las cursivas son nuestras (Habermas, 2007,p. 109ss).
} 
exigencia de reflexividad pues, como señalamos arriba, la pragmática del lenguaje muestra que todo discurso supone necesariamente la consideración que tendría una segunda persona sobre mí $^{149}$. Acudir a la racionalidad discursiva permite salir del paradigma de la filosofía de la consciencia sin sacrificar la reflexividad. Es por ello que Habermas sostiene que la capacidad racional puede ser valorada por la reflexividad que se manifiesta discursivamente. Sólo ella nos permite dar explicaciones de las pretensiones de validez de nuestras creencias, nuestros actos y nuestros dichos sin tener que remitir a una consciencia individual encerrada en sí misma: "Es solamente en el marco de argumentaciones donde las pretensiones de validez sostenidas implícitamente con un acto de habla sólo pueden, como tales, ser tematizadas y sometidas a examen mediante razones"(Habermas,2007,p.108) . Apelar a la discursividad implica, como vimos, asumir la presencia de al menos una segunda persona a la cual mis explicaciones deben parecerle racionales, esto, a su vez, nos obliga a suponer la existencia de un mundo de razones compartidas ${ }^{150}$ en el que la validez de mis juicios no puede ser valorada únicamente por mí subjetividad. Se entiende así el importantísimo papel de la racionalidad comunicativa en general y, particularmente, el de su derivación discursiva en la filosofía de Habermas.

Estas consideraciones resultan necesarias para entender el punto que verdaderamente nos interesa. Una vez que la racionalidad es caracterizada mediante su capacidad de una reflexividad que se manifiesta discursivamente, Habermas define las tres raíces antes mencionadas. Cada una adquiere sus determinaciones particulares en estrecha relación con

\footnotetext{
149 Ibid.

${ }^{150}$ Para Habermas la racionalidad comunicativa de la que deriva la racionalidad discursiva posibilita una esfera de entendimiento: "la cual asegura a los hablantes un mundo de la vida intersubjetivamente compartido $\mathrm{y}$, con ello, un horizonte dentro del cual todos pueden referirse a un mundo objetivo que es el mismo para todos"(Habermas, 2007, p. 107).
} 
la estructura que le es inherente, de tal forma que las actividades exploradas por el alemán -saber, hacer, hablar- son consideradas racionales en tanto puedan ser vertidas en una discurso que, dado el caso y encuadrado en la estructura que le es propia, sería capaz de justificar racionalmente sus pretensiones de validez no sólo bajo los parámetros del sujeto que realiza dicha actividad, sino considerando la aceptabilidad que tendrían en un mundo intersubjetivo:"El éxito ilocutivo de un acto de habla se mide por el reconocimiento intersubjetivo que encuentra la pretensión de validez que en él se sostiene"(Habermas, 2007, 109).

En clara deuda con una división semejante planteada por Kant en la Crítica del juicio ${ }^{151}$ Habermas señala que: 1) La validez de enunciados con pretensiones cognoscitivas supone el apego a una estructura epistémica basada en proposiciones y juicios. Somos racionales cuando sabemos por qué nuestros juicios (manifestados mediante oraciones asertivas) pueden ser considerados verdaderos no sólo por mí sino por un conjunto de subjetividades racionales ${ }^{152}$. 2) La validez de nuestros actos con pretensiones técnico-prácticas; es decir, "exclusivamente" guiados por el éxito en mi relación ora con el mundo objetivo, ora con otros sujetos, supone el apego a una estructura teleológica. Actuamos racionalmente cuando, en caso de que se nos pidiera, nuestras oraciones intencionales pudieran ser justificadas a través de una explicación de por qué nuestras acciones tuvieron éxito o lo tendrían en condiciones normales ${ }^{153}$. 3) El tercer caso es el más complejo. Aquí el uso de expresiones lingüísticas ya no sólo enuncia estados de cosas (oraciones asertivas) o las intenciones de un hablante (oraciones intencionales), sino que también manifiesta otra

\footnotetext{
${ }^{151}$ (Cfr, Kant,2003,BXII).

${ }^{152}$ (Cfr, Habermas, 2007,p.103-104).

153 (Cfr,Habermas 2007,p.105-106).
} 
pretensión: generar una relación de entendimiento entre al menos dos personas. La pretensión de que mis actos de habla sean comprendidos y aceptados (capacidad ilocutiva) supone una estructura comunicativa. De tal manera que en este caso la racionalidad depende de la posibilidad de explicar mediante un discurso las razones que, en condiciones normales, harían que mis actos de habla pudieran ser comprendidos y, dado el caso, aceptados:

[...]llamamos racionales no solamente a los actos de habla válidos, sino a todos los actos de habla comprensibles, respecto a los cuales el hablante puede, en las circunstancias dadas, cargar con una garantía creíble respecto a su contenido, en el sentido de que las pretensiones de validez sostenidas mediante el acto de habla podrían, en caso necesario, hacerse efectivas discursivamente"( Habermas, 2007,p.107).

Ahora bien, a diferencia de la estructura de racionalidad comunicativa, la racionalidad epistémica y la racionalidad teleológica no nos remiten, en primera instancia, a un uso comunicativo del lenguaje, pues las oraciones enunciativas o intencionales que ellas generan no necesariamente se dirigen a un destinatario ${ }^{154}$; sin embargo en la medida en que tanto las pretensiones epistémicas, como teleológicas deben pasar por el discurso para ser justificadas ${ }^{155}$ resulta lógico inferir que necesariamente deben cumplir, también, los requisitos de validez propios de una actividad ilocutiva. Es en ese sentido, y no porque posea un estatuto ontológico mayor, que Habermas le asigna un valor privilegiado a la

\footnotetext{
${ }_{154}^{154}(C f r$,Habermas, 2007,p.109-110).

${ }^{155}$ Habermas distingue entre el uso comunicativo y no comunicativo del lenguaje (Habermas,2007,p.109112), si bien las formulaciones epistémicas y teleológicas pueden ser recreadas por una conciencia sin pretensión comunicativa, la posibilidad siempre latente de que estas sean puestas en cuestión obliga a considerar su posible justificación ante los otros. En ese sentido estas formulaciones por más privadas que parzcanposeen siempre una veta comunicativa
} 
actividad comunicativa; en última instancia de ella depende la justificación racional de las otras dos

La actividad comunicativa, sin embargo, no sólo recubre las otras formas de racionalidad, sino que, por sus propias características, es su estructura la que nos orienta para comprender los procesos normativos. En este sentido nos interesa destacar un último elemento de la postura habermasiana. Como vimos, la acción comunicativa se encarga de solventar las necesidades de entendimiento entre, al menos dos personas; tomando como base esta caracterización el alemán distingue la actividad comunicativa dirigida al simple entendimiento y la actividad dirigida al acuerdo. La primera resulta más "débil" pues sólo requiere que la persona interpelada acepte la pretensión de veracidad que se le propone, pero no requiere obligatoriamente que convenga con las razones esgrimidas por la primera persona ${ }^{156}$. El acuerdo, por su parte, es más "fuerte" ya que supone una vinculación de voluntades mediante una libre decisión a partir de la cual pueden asumirse obligaciones ${ }^{157}$. Por un lado la actividad orientada al acuerdo se distingue de la actividad teleológica, pues esta última únicamente se dirige al actor que la pone en juego, mientras que aquella supone la existencia de razones que no pueden agotarse en un sólo individuo; por otro lado, se distingue de la actividad epistémica exclusivamente referida a estados de cosas, porque el acuerdo tiende a la "satisfacción de expectativas normativamente vinculantes"(Habermas, 2010,p.116). La razonabilidad de oraciones con presunciones normativas se halla, entonces, en la capacidad de justificar las razones que en "situaciones normales" la harían comprensible y, dado el caso, aceptable intersubjetivamente. En resumen este es el planteamiento que Habermas presenta en "Racionalidad del entendimiento. Aclaraciones al

\footnotetext{
${ }^{156}$ (Cfr, Habermas,2007,p. 117-118).

157 (Cfr, Habermas, 2007,p. 116).
} 
concepto de racionalidad comunicativa desde la teoría de los actos de habla", artículo que, por cierto, el propio autor considera como un resumen acabado destinado a clarificar su concepto de racionalidad comunicativa. Ahora bien, incluso sin cuestionar el proceder teórico del alemán surgen algunas dificultades dentro de su propio planteamiento. Veamos.

Si el alemán se limitara a afirmar que la acción comunicativa orientada al acuerdo puede ser justificada racionalmente en caso de que en "situaciones normales" se aceptada libremente por dos o más personas, inevitablemente surge la preguntar por los criterios que permiten calificar a una situación como "normal". Habermas comprende bien esto y, por ello, agrega que esas justificaciones sólo son posibles si asumimos que:

[...]debe conocerse el contexto normativo que explica por qué un actor se siente autorizado u obligado a realizar una determinada acción o por qué puede contar con que el destinatario obedecerá un imperativo. En la medida en que los participantes reconocen intersubjetivamente un trasfondo normativo (por ejemplo, de un mundo de la vida común) pueden aceptar como válidos actos de habla regulativos por las mismas razones"(Habermas, 2007,p.116).

El alemán es completamente consciente de que la pretensión de validez propia de la acción comunicativa, en lo que respecta a la vinculación por normas y su posible corrección, supone una consideración contextual. Es decir, en la medida en que los sujetos comparten un mundo de la vida común ellos conocen qué situaciones resultan "normales" al momento de llevar a cabo una exigencia normativa. Esta aclaración puede verse de dos maneras, desde una perspectiva permite solucionar algunos problemas epistemológicos, pero desde otra abre la puerta a una buena cantidad de cuestionamientos. En efecto, a nivel epistemológico semejante afirmación le permite alejarse tanto de una argumentación meramente formal, como del relativismo, pues logra sostener que las pretensiones de 
validez correspondientes a la corrección y la aceptación de normas dependen tanto de su adecuación a una estructura formal que le es inherente, como a una objetividad construida y compartida por un mundo intersubjetivo (lo que podríamos llamar una objetividad no transhistórica). Con ello reconoce que no hay una normatividad preestablecida y válida para siempre, aunque acepta la existencia de una serie de pretensiones inherentes a las estructuras de nuestra racionalidad. Estas pretensiones son ineludibles, no en tanto "condiciones universales de toda experiencia posible", sino: "En el sentido gramatical que resulta de la «inevitabilidad» que resulta [sic.] de los nexos conceptuales internos de un sistema de comportamiento guiado por reglas en el que nos hemos socializado y que, en cualquier caso, «para nosotros es irrebasable»” (Habermas,2008A, p. 19). Es así como Habermas cree solucionar viejos problemas epistemológicos, pues se aleja tanto de escépticos como de relativistas, al tiempo que funda su teoría en una argumentación "postmetafísica" que rehúye de todo universalismo fundado en lo dado.

Pero, por el otro lado, Habermas abre la pregunta sobre las condiciones que permiten que en un contexto dado una situación se vuelva normal y, por lo mismo, pueda ser justificada su pretensión normativa. Es decir, muestra que, amén de conocer cuál es la estructura de nuestra racionalidad comunicativa, es necesario analizar el contexto de razones compartidas para dar cuenta de la legitimidad de las normas que nos rigen. Esto, al menos, nos habla de que existe un campo de reflexión posible que corre de forma paralela al trabajo analítico dirigido a hallar la estructura de nuestra racionalidad. Ese campo de reflexión, sin duda, se encuentra íntimamente ligado al proceso de comprensión de nuestra normatividad. De tal manera que, para tener una comprensión completa de los procesos de normatividad no basta 
un análisis de la estructura de las raíces de racionalidad para determinar la validez de su uso, sino que hace falta una comprensión de las formaciones normativas efectivas.

Caeríamos en un error si como Habermas observamos que la fundamentación normativa que realiza tiene la intención de sustentar una Teoría social capaz de explicar los fenómenos que aquejan a las sociedades del capitalismo tardío. En el segundo volumen de Teoría de la acción comunicativa el alemán intenta poner a funcionar su fundamentación normativa en una Teoría social que discute largamente tesis sociológicas como las de Durkheim, Parsons, Weber y Marx ${ }^{158}$.

Judith Butler partiéramos de esta distinción para criticar a Habermas. Ella piensa erróneamente que, en ese sentido, el epíteto de a-crítico destinado a Foucault se vuelve contra Habermas :

In making this kind of criticism of critique, Habermas became curiously uncritical about the very sense of normativity he deployed. For the question, "what are we to do?" presupposes that the "we" has been formed and that it is known, that its action is possible, and the field in which it might act is delimited. But if those very formations and delimitations have normative consequences, then it will be necessary to ask after the values that set the stage for action, and this will be an important dimension of any critical inquiry into normative matters ${ }^{159}$.

Independientemente de si Butler tiene razón o no en su valoración de la postura habermasiana nos muestra las coordenadas del problema a debatir. La interrogación que está en juego es la siguiente: ¿Acaso la particularidad de los contenidos concretos de los

\footnotetext{
${ }^{158}$ A diferencia de Butler nosotros no pensamos que el alemán se vuelva a-crítico, nos parece discutible la pretensión de que la única forma de llevar a cabo un trabajo crítico supone, necesariamente, seguir el camino de la fundamentación normativa y la creencia de que la ausencia de ella vuelve inútil el tipo de planteamiento ${ }_{159}$ desarrollado por Foucault. 
contexto compartidos en cada una de las experiencias no se vuelve esencial al memento de valorar la validez o la legitimidad normativa de un juicio, no ya en su mera construcción conceptual, sino cuando requerimos criterios de evaluación de situaciones efectivas? Adelantemos desde ahora la respuesta de Foucault, él piensa que es imposible disociar nuestras evaluaciones de los contexto efectivos. Habermas podría señalar, y tendría razón, que por su propia dimensión contrafáctica una fundamentación normativa puede y debe ser indiferente a los contenidos efectivos de los contextos compartidos, pues, de otra manera su pretensión de universalidad sería insostenible. Pero el verdadero problema no es ese, independientemente de su fundamentación teórica, esa normatividad debe servir como elemento crítico de contextos y situaciones histórico-concretas.

Esto nos lleva, sin lugar a dudas, a otra pregunta: ¿Son del todo indiferentes las condiciones históricas de formación de una cierta normatividad de aquello que se asume como válido en un contexto compartido? La respuesta de Habermas es un no rotundo, la dimensión normativa es del todo independiente de los procesos históricos. Esto porque independientemente de cualquier proceso histórico la estructura de la racionalidad comunicativa es la misma, para hablar de un acuerdo, en esencia, se requiere de dos voluntades "libres" que acepten las pretensiones de imperativos ajenos. En el fondo, Habermas sigue a la tradición contractual y a Kant en la recuperación del principio jurídico "Donde hay acuerdo libre no hay injustica", las normas pueden considerarse validas cuando son el resultado de un acuerdo libre.

De esta afirmación depende por completo la teoría social y el diagnóstico de la modernidad habermasiano. La pregunta que a través de Foucault deseamos poner en la mesa es la siguiente: ¿la distinción normativa que le permite a Habermas sostener que las patologías 
sociales se pueden explicar por la intromisión de la esfera vinculada a la racionalidad teleológica-instrumental sobre la esfera del entendimiento comunicativo es suficiente para entender la multiplicidad y la especificidad de nuestros conflictos sociales?, y, de la mano de la misma: ¿Acaso no se requiere, también, un instrumento mucho menos general, más específico y menos totalizante para comprender nuestro presente? ${ }^{160}$.

\title{
3.2.- Procesos de racionalización y gubernamentalización. El análisis histórico genealógico
}

\author{
y arqueológico como fundamento de una crítica social.
}

Como hemos venido reiterando, la crítica de Habermas a Foucault se centra en el supuesto de que éste último reduce el desarrollo de la modernidad a relaciones de poder. Según el alemán, el francés se vuelve incapaz de explicar los procesos de racionalidad en términos de entendimiento debido a la identificación inmediata de poder y razón. En el fondo, la crítica de Habermas al francés descansa en la concepción que, según el alemán, Foucault tiene de la idea de racionalidad. De manera semejante a las críticas que dirige a Marx y

\footnotetext{
${ }^{160}$ No es este el lugar adecuado para discutir este tema pero podemos dejar planteada la siguiente cuestión: ¿en realidad el alemán supera los dualismos entre forma/materia y finitud/infinitud presentes en Kant al reformular el concepto de racionalidad acudiendo a una discursividad reflexiva circunscrita a raíces vinculadas a sus estructuras "inherentes"?. En el Prefacio a la Lógica Hegel critica la postura de Kant por varias razones, una de ellas se refiere al problema que supone establecer una serie limitada de categorías inherentes al sujeto. El esquematismo categorial de Kant deriva en un formalismo radical porque de antemano establece un número limitado de categorías válidas a las que el proceso efectivo del pensamiento debe adaptarse en sus pretensiones de legitimidad. La realidad infinita debe circunscribirse a una serie finita de categorías que, por su propia finitud, siempre se hallarán apartadas del proceso efectivo y sólo podrán aspirar a juzgar si un juicio se adecua formalmente a las exigencias de su pretensión, pero no es capaz de analizar contenidos concretos y particulares: "Pues los conceptos, considerados así, como puras formas, distintas del contenido, se aceptan como fijados en una determinación que les da el aspecto de algo limitado y los hace incapaces de abarcar la verdad que es en sí infinita”(Hegel,1976,p.37). Si bien Habermas pretende superar este formalismo acudiendo a la pragmática del lenguaje -lo que supone una análisis no ya anclado en un sujeto trascendental sino en el movimiento efectivo de el lenguaje presente en nuestra vida cotidiana-, la deducción de las estructuras "inherentes" al lenguaje deriva en una serie de criterios igualmente formales que sólo sirven para indicarnos si nuestras pretensiones de validez son legitimas, pero se nos presentan igualmente de incapaces de analizar los contenidos concretos de nuestra acción comunicativa efectiva. Habermas acude a la contextualización de una objetividad intersubjetiva para evitar caer en dicho formalismo, pero, a nuestro parecer, no basta con sólo hacer mención de la misma para saldar el problema, la única manera de no encerrarnos en un formalismo aislado de lo concreto pasa por analizar efectivamente los procesos de constitución y formación de esa racionalidad intersubjetiva.
} 
Weber, el autor de Facticidad y validez denuncia que la concepción de racionalidad foucaultiana es restrictiva. Según Habermas, Foucault olvida la dimensión constructiva de la misma e, influenciado por Nietzsche, parte de una idea unilateral de razón ligada a la fuerza y a la violencia.

Empecemos por mostrar que esta afirmación es del todo insostenible. La revisión que hemos hecho de los conceptos de gobierno y gubernamentalidad puede ayudarnos bastante para entender cuál es la idea de racionalidad que Foucault sostiene. Hemos señalado que Foucault entiende por "gubernamentalidad", la racionalidad inmanente a ciertas prácticas discursivas y no discursivas mediante las cuales se pretende conducir y delimitar el campo de acciones de los otros. Al definir los procesos de gobierno como formas de racionalidad, Foucault deja claro que no se adhiere a la postura clásica de la filosofía, según la cual el poder era ajeno a la razón y la razón al poder. El poder no sólo es racionalizable, sino que la razón misma genera formas de gobierno y prácticas de acción destinadas a la conducción de los otros. Esto, sin embargo no implica, como piensa Habermas, que Foucault considere que la razón sea una emanación del poder, sino que poder y razón no son esencialmente contradictorios. Las relaciones de poder se definen en el mismo movimiento en que la propia racionalidad se determina a sí misma. No hay, pues, ni una racionalidad previa a su desenvolvimiento efectivo en la realidad y a las confrontaciones intersubjetivas con las que se topa, ni una fuerza violenta que genere relaciones de poder al costado de la razón. En el fondo, esta concepción de racionalidad implica una serie de definiciones epistemológicas y ontológicas de suma relevancia, no sólo se trata de afirmar que el poder y la razón no son contradictorios, sino de asumir de manera absolutamente seria que no es posible analizar la razón abstrayéndola de las prácticas mismas en que ésta se manifiesta. Todavía más, no 
sólo se trata de afirmar que todo análisis que abstraiga la razón de las prácticas efectivas en que se manifiesta es insuficiente, sino de sostener que formas la razón no es otra cosa que el desarrollo absolutamente autosuficiente de las prácticas humanas en su enfrentamiento con los otros y con el mundo. Sin duda, el francés no es el primero en defender esta tesis, una larga línea de pensadores que inicia en Hegel, pasa por Marx y Nietzsche, y llega a Bachelard y Canguillem, han sido defensores, aún con todas las divergencias existentes entre sus filosofías, de una idea muy clara: no existe escisión entre la forma de la razón y los contenidos que ésta adquiere o, para decirlo de otra manera, la forma de la razón está determinada por el contenido. Intentar separar los criterios de razonabilidad del proceso histórico que las hace posibles es, en todo caso, una operación que nunca podrá dar cuenta de la razón efectiva. Es necesario, pues, adentrarse en aquello que le da contenido al pensamiento y, según Foucault, ese contenido proviene de la historia y de las prácticas que en ellas se reproducen. La razón no es un medio, ni un aparato que nos permite acceder a una realidad que, en esencia, le sería distinta.

En una entrevista de 1982, Foucault deja claro esto afirmando:

[...]mi problema no es, finalmente, el de la irracionalidad como invariante antropológica. No creo que se pueda hablar de "racionalización" en sí, sin suponer por una parte un valor razón absoluto y sin exponerse por el otro a introducir un poco de todo en la sección de las racionalizaciones [...]Digamos que no se trata de calibrar unas prácticas con la medida de una racionalidad que llevaría a apreciarlas como formas más o menos perfectas de racionalidad, sino, preferentemente, de ver cómo se inscriben en unas prácticas o en unos sistemas de prácticas, unas formas de racionalizaciones y qué papel desempeñan en ellas.( Castro,34)

Se trata, entonces, de una posición epistemológica y ontológica de largo alcance, la cual parte de una idea central: la razón se constituye de forma permanente a través de las 
prácticas concretas en las que el sujeto y el objeto se determinan mutuamente. Ahora bien, sería falso que estableciéramos que lo que distingue a Habermas de Foucault es el hecho de que este último ancle la racionalidad en el presente. De hecho, el alemán intenta hacer lo mismo al recurrir al lenguaje para sustentar los criterios normativos. Como hemos dicho, la pragmática formal le permite eludir todo elemento trascendental y enraizar el fundamento de su crítica en el mundo y sólo en el mundo. La diferencia real consiste en que, mientras Habermas intenta deducir y abstraer formas de racionalidad en estado puro (ya sea teleológica, comunicativa o epistémica) para poder definir los ámbitos "legítimos" de acción y procedimiento de ciertas formas de relaciones sociales, Foucault asume que no sólo no existe ese estado de racionalidad pura, sino que la propia posibilidad de plantearse ese estado es ya una elaboración racional que subsume, lo quiera o no, formas de poder, relaciones de gobierno y largos procesos históricos.

La concepción de racionalidad que asume el francés parte de un hecho esencial: el único criterio que determina si algo es racional o no es el proceso histórico efectivo. La vinculación de razón y poder es el resultado de un hecho fundamental, las prácticas humanas construyen permanentemente los contenidos de la razón. No hay, pues, subsunción de la razón al poder o del poder a la razón, lo que hay es un proceso histórico complejo en el que, necesariamente, toda vinculación del sujeto con el objeto se racionaliza. Una de las muchas formas en que esas relaciones se manifiestan es a través de prácticas de gobierno, lo cual no quiere decir que la razón sea únicamente un instrumento de gobierno. En sus conferencias sobre las tecnologías del yo, así como en el "El sujeto y el poder", el francés explica que, al menos, existen cuatro modos de acción racional (tecnologías); a saber: 
1)tecnologías de producción, que nos permiten producir, transformar o producir cosas; 2) tecnologías de sistemas de signos, que nos permiten utilizar signos, símbolos y significaciones; 3 ) tecnologías de poder, que determinan la conducta de los individuos, lo someten a cierto tipo de fines o de dominación y que consisten en una objetivación del sujeto; 4) tecnologías del yo, que permiten a los individuos, efectuar por cuenta propia, o con la ayuda de otros, cierto número de operaciones sobre su cuerpo y su alma, pensamiento, conducta o cualquier forma de ser, obteniendo así una transformación de sí mismos con el fin de alcanzar cierto estado de felicidad, pureza, sabiduría o inmortalidad $(\mathrm{TY}, 48)$.

E inmediatamente después afirma:

Estos cuatro tipos de tecnologías casi nunca funcionan de modos separadas[...]Cada una implica ciertas formas de aprendizaje y de modificación de los individuos, no sólo en el sentido más evidente de ciertas habilidades, sino también en el sentido de adquisición de ciertas actitudes (TY, 48-49).

Ambos pasajes nos muestran dos cosas:1) Foucault no es ciego respecto a las distintas formas de racionalidad y 2) El francés sabe que los cuatro niveles analizados se implican unos a otros, la relación concreta que adquieren en ciertas formas de experiencia transforman tanto las habilidades como las actitudes de los individuos. Para él, las distintas "tecnologías" no pueden ser reducidas a la "tecnología de poder" y tampoco cree que ésta tenga un estatuto privilegiado que recorra de forma inalterable toda la modernidad. Al contrario, Foucault afirma que es casi imposible encontrar dominios de experiencias en los que estas formas de racionalidad se hallen totalmente disociadas y también piensa que no parece viable ni provechoso reducir a una sola de ellas la compleja red de relaciones que, 
de hecho, se presentan en una sociedad específica. Tres años antes, en 1978, Foucault aún no había problematizado eso que en las conferencias de 1981 llamaba "Tecnologías del yo", así que sólo hablaba de tres formas de actividad y nombraba de manera distinta cada una: en vez de hablar de tecnologías de producción hablaba de "relaciones finalistas", en lugar de hablar de tecnologías de poder hablaba de "relaciones de poder" y para referirse a las tecnologías de signos utilizaba un concepto más adecuado: "sistemas de comunicación".

Pero ya en esa división dejaba claro que: "Il n'y a pas dans une société donné un type général d'equilibre entre les activités finalisées, les systèmes de communications et les relations de pouvoir. Il y a plutôt diverses formes, diverses lieux, diverses circonstances ou occasions où ces interrelations s'ètablissent sur un modèle spéecifique (SP, 1053). En una sociedad dada no existe, pues, un sólo modelo de racionalidad, de igual forma, resulta imposible afirmar que las relaciones de las distintas "tecnologías" son homogéneas en todas las formas de experiencia. De ahí que, para Foucault, sólo se accede a una comprensión de nuestro propio presente si analizamos los diversos modos en que, en ciertos focos de experiencia concretos, estas formas de racionalidad se relacionan entre sí. Por ello, insiste tanto en no analizar nuestro presente ni en los términos de un proceso único de racionalización, ni concibiendo la modernidad de forma homogénea.

Afirmar que el poder es una tecnología racional que se caracteriza por estructurar y dirigir las conductas de los otros implica, necesariamente, evitar aquella visión binaria que pretende resolver la complejidad de las relaciones de poder mediante la sustitución de una forma de acción unitariamente negativa por otra unitariamente positiva o, lo que es lo mismo, de una forma de acción del todo legitima sobre otra del todo ilegitima. Al plantear 
el problema de las "patologías" de la razón en los términos binarios de lo legítimo y lo ilegítimo, Habermas parece facilitarse el problema. Bajo esta perspectiva resulta fácil diagnosticar los problemas de la modernidad afirmando que estos se producen por la colonización, la usurpación o la inserción ilegítima de un dominio sobre otro. Al plantear así el problema, Habermas parece haber descomplejizado a tal grado la realidad que su intento de superar el individualismo kantiano a partir del paradigma intersubjetivo que la pragmática formal del lenguaje otorga, recae en otro tipo de reduccionismo; a saber, asumir que todas las formas del conflicto social pueden explicarse bajo el modelo de la irrupción de la racionalidad teleológica -en su forma social de sistema-, sobre la racionalidad comunicativa -en la forma social del mundo de la vida-. Esta tesis parece suponer que la razón comunicativa se hallaría libre de relaciones de poder no sólo a nivel teórico, sino también en el dudosos caso de que pudiera trasladarse a situaciones reales y específicas; es decir, no sólo se sostiene que en un nivel normativo y contrafáctico el entendimiento supone una estructura de acuerdo libre de coacción - argumento defendible, sin duda-, sino que su aplicación en el plano social resolvería cualquier tipo de relación asimétrica y, sobre todo, que ella misma no podría ser parte de relaciones de poder. Sin duda se nos responderá que, al ser un modelo contrafáctico, no puede, ni debe, preocuparse por la especificidad de las situaciones efectivas, sino únicamente establecer una normatividad capaz de servirnos como estructura crítica racional. Pero el asunto que está en juego es valorar, justamente, si la capacidad de dicha estructura normativa es suficiente para dar razón de las complejas formas en que el conflicto social aparece.

Ahora bien, Habermas no reduce el modelo del conflicto social a la división binaria entre legítimo e ilegítimo por un simple capricho. Como vimos, la tres raíces de racionalidad 
que él menciona suponen una estructutura inherente que marca el objeto legítimo de su ejercicio, en el caso de la racionalidad epistémica se refiere a los objetos susceptibles de afirmaciones asertóricas; en el caso de la racionalidad teleológica se trata de nuestra vinculación a objetos como medios para llevar a cabo exitosamente un fin o, hacia otros sujetos, pero únicamente en tanto se los concibe como medios para llevar a cabo un fin de forma exitosa y en el caso de la racionalidad comunicativa se trata de la relación intersubjetiva en los niveles de la corrección de normas y el entendimiento. Por lo mismo. se puede afirmar desde una posición fundada que en el caso de que cualquiera de las tres formas de racionalidad irrumpa en un ámbito que no le corresponda, procede de manera ilegítima. Esto explica porqué la intromisión de la racionalidad teleológica en procesos estructuralmente dispuestos al entendimiento hace surgir patologías sociales. De ahí, también, que Habermas tienda a identificar de forma irreflexiva toda relación de poder con la instrumentalización o la cosificación, pues el modelo de las patologías de lo social se circunscribe a la ilegitima acción que toma al hombre por instrumento o medio ahí donde tendría que actuar el entendimiento. Por lo mismo, Habermas -y con él Honnethidentifican, erróneamente, la noción de poder de Foucault con la de instrumentalización: "Foucault está convencido de que las sociedades desarrolladas de la era moderna pueden mantenerse sólo porque una densa red de instituciones de control procura un creciente disciplinamiento del cuerpo humano, obligando al mismo tiempo a los sujetos a que organicen su vida con la racionalidad instrumental, y suprimiendo cualquier forma de resistyencia desde el inicio"(Honneth, 2009,111). Sólo porque Habermas homologa la noción de poder de Foucault con la de instrumentalización en Adorno o Weber afirma que es posible mostrar la insuficiencia de su modelo interpretativo. Si el poder ya no es ese trascendental que atraviesa la historia indefinidamente relativizando toda posible 
fundamentación de verdad o de normatividad, sino una irrupción ilegitima, basta, pues, con mostrar que es posible sustituir los procesos de instrumentalización por los del entendimiento para desterrar las amenazas de eso que, supuestamente, Foucault ve como algo necesario e irremediable.

No sólo la interpretación habermasiana es errada en su diagnóstico de la filosofía de Foucault, sino que, a nuestro parecer, también posee limitaciones en su diagnóstico de la modernidad. A diferencia de lo que hace el alemán. Foucault no reduce la problemática del poder a la irrupción ilegitima de un dominio sobre el otro. En esencia. Habermas había comprendido que la relación que tenemos con otros sujetos puede enmarcarse en dos dimensiones: en la de la racionalidad comunicativa y en el de la racionalidad teleológica. En la primera, nuestra forma de vincularnos con los otros supone lasos de entendimiento y acuerdo, en la segunda el otro es simplemente un medio más para acceder a un fin. Bajo ese esquema el conflicto social sólo puede explicarse, como ya dijimos, en los términos de una instrumentalización o una cosificación. A nuestro entender es este esquema binario el que resulta prblemático,pues obliga a reducir toda relación de asimetría a la instrumentalización o la cosificación. Cuando Foucault clasifica las modalidades de acción práctica (tecnologías) se cuida de no homologar las tecnologías de producción(finalistas o teleológicas) con las de poder para mostrar que éstas últimas no son reductibles a aquellas, sino que constituyen una forma particular de acción humana sobre otros cuya única característica es intentar dirigir sus conductas. Analizar las relaciones de poder es, pues, indagar en la multiplicidad de relaciones humanas las distintas maneras en que los hombres han gobernado a los otros, los medios que se han dado, los saberes en los que se han apoyado, los dispositivos que han puesto en marcha y los procedimientos de los que se 
han valido para dirigirlos. Sin duda el proceso de instrumentalización es uno de ellos, pero no es ni el único, ni el más importante, además que de ninguna manera puede entenderse de forma autosubsistente, sin ponerlo en relación con las formas de entendimiento, los saberes legítimos y verdaderos, que le permitieron funcionar efectivamente en un contexto real.

Esta perspectiva no rechaza ni anula la posibilidad de una filosofía dedicada a fundamentar las condiciones de legitimidad de nuestras pretensiones -aunque tampoco la asume sin más; pero si nos muestra que puede resultar del todo insuficiente si se olvida del análisis efectivo de la formación de los procesos de normatividad y veridicción. Justamente a estos nos referimos cuando decimos que Foucault no se encuentra debajo sino a un lado de Habermas. Lo que hemos querido dar a entender con esa metáfora es lo siguiente: el francés no realiza una labor arqueológica y genealogía porque ignore que es necesario partir de un suelo normativo para poder validar nuestras afirmaciones sobre la realidad de manera legítima, sino porque su objetivo es, precisamente, dar cuenta del suelo que hace posible que ciertas normas, ciertos regímenes de verdad y ciertas formas de subjetividad entren en determinados dominios de racionalidad que hasta antes no eran pensables en esos términos.

Más allá de sus posibles limitaciones, nos parece esencial reivindicar la postura crítica de Foucault como un intento serio para dar cuenta de la realidad. La gran ventaja del trabajo de Foucault consiste en que, a diferencia de Habermas, el francés no se limita a dar cuenta de las condiciones que hacen posible nuestros juicios sobre la realidad, sino que da un paso más allá e indaga las condiciones que hacen posible que en una época dada un discurso se plantee siquiera la posibilidad de formularse ciertos problemas (por ejemplo, el de las condiciones que hacen posible que nuestros juicios sean válidos). En suma, el trabajo genealógico y arqueológico del francés intenta mostrar las distintas relaciones necesarias 
para que la emergencia de la verdad se ponga en juego; ahora bien, dado que esa verdad siempre está inscrita en un mundo que no se agota en el discurso, nuestro autor se ve impelido a analizar las condiciones históricas generales que dan cuenta de la estructuración de los propios discursos. A nuestro entender, este trabajo debe considerarse esencial si queremos tener una visión crítica del presente, pues nos permite ampliar el panorama de nuestra propia actualidad para comprender la trama de relaciones en las que, como sujetos, estamos inscritos. 


\section{BIBLIOGRAFÍA}

Allen, Barry, Government in Foucault, in: Canadian Journal of Philosophy, Vol. 21, No. 4, 421- 440 .

Althusser, Louis, La filosofía como arma de la revolución, Siglo XXI editores, México, 2005.

Amin, Samir, El capitalismo en la era de la globalización, Paidós, Barcelona, 1999.

Andrew Barry, Thomas Osborne \& Nikolas Rose (eds.), Foucault and Political Reason. Liberalism, Neo-Liberalism and Rationalities of Government, London: UCL Press, 1996.

Arendt, Hannah, Sobre la violencia, Alianza, Madrid, 2006.

Balbier, Deleuze, Dreyfus, et. al, Michel Foucault. Filósofo, Editorial Gedisa, Barcelona, 1990.

Berman, Marshal, Todo lo sólido se desvanece en el aire. La experiencia de la modernidad, Siglo XXI, México, 2008.

Boullant, Francois, Michel Foucautl y las prisiones, Editorial Nueva Visión, Buenos Aires, 2004.

Burchell, Graham; Gordon, Colin and Miller, Peter, The Foucault Effect. Studies in Governmentality, Ediciones University of Chicago Press, Great Bretain, 1991.

Butler, Judith, Los mecanismos psíquicos del poder. Teorías sobre la sujeción, Cátedra, Madrid, 2001.

Castro Gómez, Santiago, Historia de la gubernamentalidad. Razón de Estado, liberalismo y neoliberalismo en Michel Foucault, Siglo del Hombre Editores, Bogotá, 2010.

Couzens Hoy, David (comp.), Foucault, Ediciones Nueva Visión, Buenos Aires, 1988.

Cusset, Haber (dir.), Habermas - Foucault. Trayectorias cruzadas, confrontaciones críticas, Ediciones Nueva Visión, Buenos Aires, 2007.

Davidson, Arnold, La aparición de la sexualidad, Alpha Decay Ediciones, Barcelona, 2004.

Dean, Mitchell, Critical and Effective Histories. Foucault's Methods and Historical Sociology, Routledge London/New York, 1994.

, La policía de las familias, Ediciones Nueva Visión, Buenos Aires, 2008. 
Donzelot, Jacques, La invención de lo social. Ensayo sobre la declinación de las pasiones políticas, Ediciones Nueva Visión, Buenos Aires, 2007.

Dreyfus y Rabinow, Foucault más allá del estructuralismo y la hermenéutica, UNAM, México, 1988.

Eribon, Didier, Michel Foucault, Anagrama, Barcelona, 2004.

Foucault, Michel, Arqueología del Saber, Siglo XXI editores, México, 2007.

, Defender la Sociedad, Fondo de cultura económica, México, 2006.

_, Dits et écrits II, Gallimard, París, 2001.

2010.

, El coraje de la verdad, Fondo de cultura económica, Buenos Aires, Aires, 2010.

, El gobierno de sí y de los otros, Fondo de cultura económica, Buenos Aires, 2007.

, El nacimiento de la biopolítica, Fondo de cultura económica, Buenos

, El nacimiento de la clínica, una arqueología de la mirada médica, Siglo XXI editores, Buenos Aires, 2004.

, El orden del discurso, Tusquets editores, Barcelona, 2005.

, El poder psiquiátrico, Fondo de cultura económica, Buenos Aires, 2007.

, “Foucautl”, en: Foucault, Michel, Obras esenciales, Paidós, Barcelona,

2010.

, Historia de la Locura en la época clásica I., Fondo de cultura económica, México, 2006.

, Historia de la Locura en la época clásica II., Fondo de cultura económica, México, 2002.

, Historia de la sexualidad 1. La voluntad de saber, Siglo XXI editores, México, 2005.

, Historia de la Sexualidad 2. El uso de los placeres, Siglo XXI editores, México, 2005. 
México, 2007.

, Historia de la Sexualidad 3. La inquietud de sí, Siglo XXI editores, , Introduction to Kant's Anthropology, Semiotext(e), Los Angeles, 2008.

, "La locura y la sociedad", en: Foucault, Michel, Obras esenciales,

Paidós, Barcelona, 2010.

, La verdad y las formas jurídicas, Gedisa, Barcelona, 2008.

, Las palabras y las cosas, Siglo XXI editores, México 2007.

, "Le sujet et le pouvoir", en: Foucoult, Michel, Dits et écrits II. 1976-

1988, Gallimard, París, 2001.

_, Los anormales, Fondo de cultura económica, México, 2006.

, Microfísica del poder, Las ediciones de la Piqueta, Madrid, 1993.

, El nacimiento de la biopolítica, FCE, Buenos Aires, 2010.

, Obras esenciales, Paidós, Madrid, 2010.

Aires, 2006.

, Seguridad, territorio y población, Fondo de cultura económica, Buenos

, Tecnologías del yo, Paidós, Barcelona, 1990.

, Una lectura de Kant. Introducción a la antropología en sentido pragmático, Siglo XXI Editores, Buenos Aires, 2009.

México, 2005.

, Vigilar y Castigar, nacimiento de la prisión, Siglo XXI editores,

Gros, Frédéric et Davidson, Arnold (Dir.), Foucault, Wittgenstein: de possible rencontres, Ediciones Kimé, París, 2011.

Gros, Frédéric, Michel Foucault, Amorrortu editores, Buenos Aires-Madrid, 2007.

Grossi, Paolo, El orden jurídico medieval, Editorial Marcial Pons, Madrid, 1996.

Habermas, Jürgen, Acción comunicativa y razón sin trascendencia, Paidós, Barcelona, 2008 A. 
, El discurso filosófico de la modernidad, Katz, Uruguay, 2010.

, Facticidad y validez, Trotta, Madrid, 2000.

, Teoría de la acción comunicativa, I. Racionalidad de la acción y

racionalización social, Taurus, México, 2008 B.

, Teoría de la acción comunicativa, II. Crítica de la razón funcionalista,

Taurus, México, 2008 C.

, Teoría y praxis, Editorial Altaya, Madrid, 1999.

, Verdad y justificación, Editorial Trotta, Madrid, 2007.

, Ciencia de la lógica, Editorial Hachette, Buenos Aires, 1976.

Hegel, G. W. F., Fenomenología del espíritu, FCE, México, 1966.

, Fundamentos de la Filosofía del Derecho, Prodhufi, Madrid, 1993.

Hirschman, Albert O., Las pasiones y los intereses, FCE, México, 1978.

Hobbes, Thomas, Leviatán. O la materia, forma y poder de una república eclesiástica y civil, FCE, México, 2006.

Honneth, Axel, Crítica del agravio moral. Patologías de la sociedad contemporánea, FCE, Buenos Aires, 2009 A.

, Crítica del poder. Fases en la reflexión de una teoría crítica de la

sociedad, Editorial Mínimo Tránsito, Madrid, 2009 B.

, Patologías de la Razón. Historia y actualidad de la teoría crítica, Katz,

Buenos Aires, 2009C.

Kant, Immanuel, Crítica del discernimiento, Machado Libros, Madrid, 2003.

Kant, Emmanuel, Crítica de la razón pura, Taurus, México, 2006 A.

,Filosofía de la historia, FCE, México, 2006 B.

Kelly, Michael (ed.), Critique and Power: Recasting the Foucault/Habermas Debate, The MIT Press, Baskerville - United States of America, 1995.

Le Blanc, Guillaume, Canguilhem y las normas, Editorial Nueva Visión, Buenos Aires, 2004.

,El pensamiento Foucault, Amorrortu Editores, Buenos Aires, 2006. 
Lecourt, Dominique; Cacciari Massimo, et. al, Disparen sobre Foucault, Ediciones El Cielo por Asalto, Buenos Aires, 1993.

Lemke, Thomas, Economy and Society, Volume 30, Number 2, May 2001: 190-207.

Lemke, Thomas; Legrand, Stephan, et. al, Marx y Foucault, Ediciones Nueva Visión, Buenos Aires, 2006.

Leyva, Gustavo (Ed.), La Teoría Crítica y las tareas actuales de la crítica, Anthropos UAM, Barcelona, 2005.

Locke, Jhon, Ensayo sobre el gobierno civil, Alianza, Madrid, 2005.

Marx, Carlos, Contribución a la crítica de la economía política, Siglo XXI editores, México, 2008.

México, 2001.

, El capital. Crítica de la economía política I, Fondo de cultura económica,

Melossi, Dario; Pavarini, Massimo, Cárcel y fábrica. Los orígenes del sistema penitenciario (siglos XVI al XIX), Siglo XXI Editores, México, 2008.

Nietzsche, Friederich, La genealogía de la moral, Alianza, Madrid, 2006.

Potte-Bonneville, Mathieu, Michel Foucault, la inquietud de la historia, Editorial Manantial, Buenos Aires, 2004.

Rosanvallon, Pierre, El capitalismo utópico, Ediciones Nueva Visión, Buenos Aires, 2006.

Rousseau, Jean-Jacques, El contrato social, Alianza, Madrid, 2002.

Sabine, George, H., Historia de la teoría política, FCE, México, 2006.

Sassen, Saskia, Territorio, autoridad y derechos. De los ensamblajes medievales a los ensamblajes globales, Editorial Katz, Madrid, 2010.

Smith, Adam, Investigación sobre la naturaleza y causas de la riqueza de las naciones, Fondo de cultura económica, México, 2006.

Senellart, Michel, Les arts de gouverner. Du regimen médiéval au concept de gouvernement, Paris: Seuil,1995.

Serrano Gómez, Enrique, Legitimación y racionalización. Weber y Habermas: la dimensión normativa de un orden secularizado, Anthropos - UAM, Barcelona, 1994.

Terrel, Jean, Politiques de Faucault, Presses Universitaires de France, París, 2010. 
Veyne, Paul, Foucault. Sa pensée, sa personne, Albin Michel, París, 2008. 
Alal

Casa abierta al tiempo

UNIVERSIDAD AUTÓNOMA METROPOLITANA

$$
\begin{array}{lr}
\text { Fecha : } & 11 / 07 / 2012 \\
\text { Página: } & 1 / 1
\end{array}
$$

CONSTANCIA DE PRESENTACION DE EXAMEN DE GRADO

La Universidad Autónoma Metropolitana extiende la presente CONSTANCIA DE PRESENTACION DE EXAMEN DE GRADO de MAESTRO EN HUMANIDADES (FILOSOFIA) del alumno JOSE RICARDO BERNAL LUGO, matricula 210381549, quien cumplió con $10 s 150$ créditos correspondientes a las unidades de enseñanza aprendizaje del plan de estudio. Con łecha dieciséis de julio del 2012 presentó la DEFENSA de su EXAMEN DE GRADO cuya denominación es:

GOBIERNO $Y$ GUBERNAMENTALIDAD EN LA OBRA DE MICHEL FOUCAULT

Cabe mencionar que la aprobación tiene un valor de 40 créditos y el programa consta de 160 créditos.

El jurado del examen ha tenido a bien otorgarle la calificación de:

APROBAR

JURADO

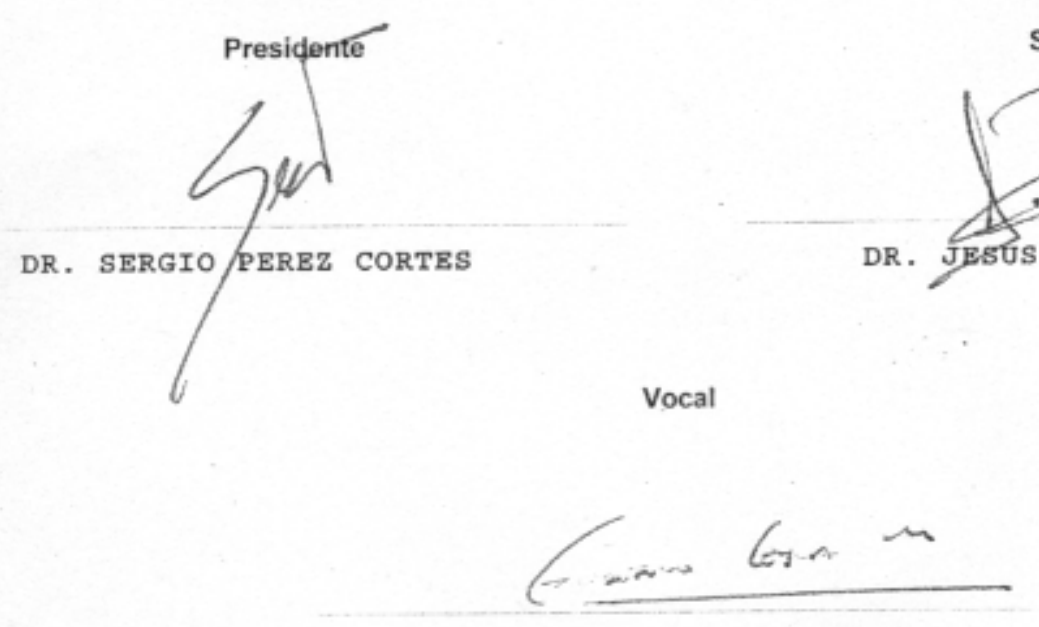

DR. GUSTAVO LEYVA MARTINEZ

UNIDAD IZTAPALAPA

Coordinación de Sistemas Escolares

Av. San Rafael Atlixco 186, Col. Vicentina, México, DF, CP 09340 Apdo. Postal 555-320-9000, Tels. 5804-4880 y 5804-4883 Fax: $5804-4876$ 